\author{
UNIVERSIDADE DE SÃO PAULO - USP \\ INSTITUTO DE ELETROTÉCNICA E ENERGIA - IEE \\ PROGRAMA INTERUNIDADES DE PÓS-GRADUAÇÃO EM ENERGIA - PIPGE
}

\title{
Reflorestamento no Brasil e o Protocolo de Quioto.
}

Autor: Gustavo D'Almeida Scarpinella

Orientador: Prof. Dr. José Manuel Vasconcelos Martins

São Paulo

Maio - 2002 


\section{Dedicatória}

Dedico este trabalho com o mesmo carinho e atenção aos meus pais, Cláudio Antonio e Nívea e, à minha irmã, Érika Milena, extensões de minha vida. 


\section{Agradecimentos}

A CAPES, pelo apoio financeiro.

A Adaljisa Furlan da Paixão, Júlio César Theodoro, Maria da Fátima A. Mochizuki, Maria Penha da Silva Oliveira, Nazareth Comerço e Vilma Bortoleto pelos favores prestados e pela amizade cultivada.

A Amantino Ramos de Freitas, Andréia Maffeis, Célio Bermann, Cíntia Rodrigues de Souza, Cláudio Antônio Scarpinella, Edmilson Santos, Edson Gomes, Elaine Aparecida Campagnoli, Érika Milena D'Almeida Scarpinella, Estanislau Luczinsky, Humberto Rocha, Ildo Luis Sauer, Joaquim Simões, José G. Dominguez, José Goldemberg, José Paulo Vieira, Laurito Bacaxixi, Marcelo Ambrogi, Marcelo Onuki, Márcio Nahuz, Maria Luíza Otero D’Almeida Lamardo, Miriam Hinostroza Suarez, Mauro Sérgio Vianello Pinto, Murilo W. Fagá, Nívea Otero D’Almeida Scarpinella, Núria Pardillos Vieira, Osvaldo Stella Martins, Paul Singer, Pedro Leite da Silva Dias, Roberto Jover Lázaro, Roberto Zilles, Sinclair Mallet Guy Guerra, Suani Teixeira Coelho e Walter de Paula Lima, pela ajuda em algum ou muitos momentos do desenvolvimento deste trabalho.

A José Manuel Vansconcelos Martins, pela orientação.

Aos colegas do PIPGE, pelo companheirismo, pelos conselhos e pela amizade.

Aos meus outros amigos, não presentes nesta lista, mas em minha vida.

Agradecimentos especiais a Rubens Garlipp e Marco Antônio Fujihara, pela humildade, pelos créditos e pela atenção despendida. 


\section{A- Sumário}

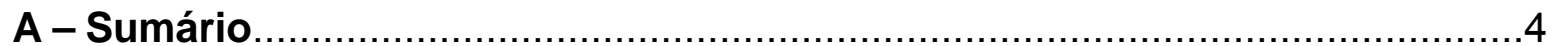

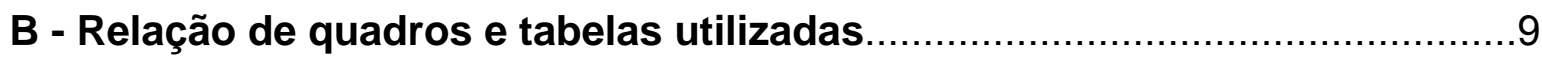

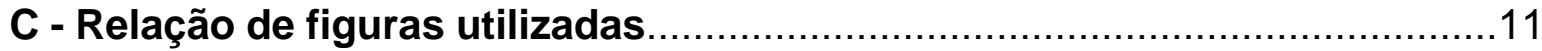

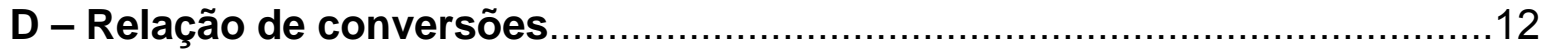

E - Relação de espécies vegetais citadas e seus nomes científicos.............13

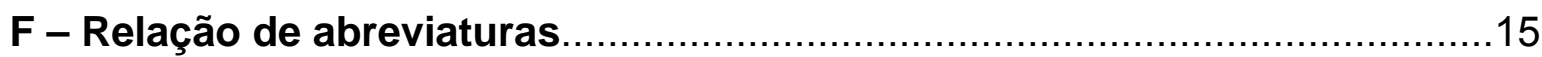

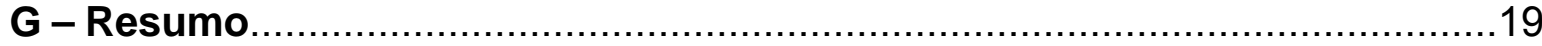

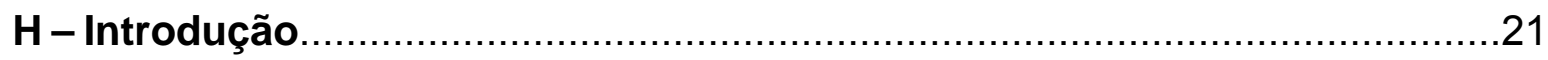

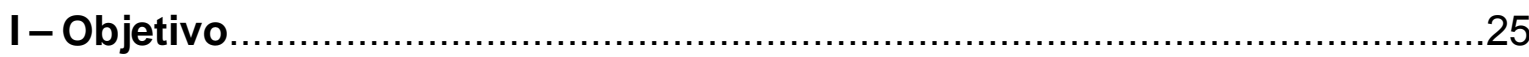

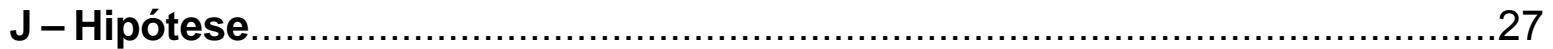

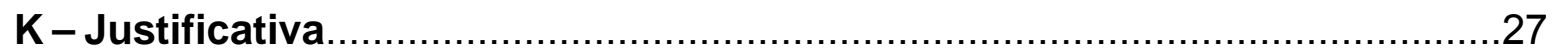

\section{CAPÍTULO I}

1. Mudanças climáticas e o meio ambiente.................................................30

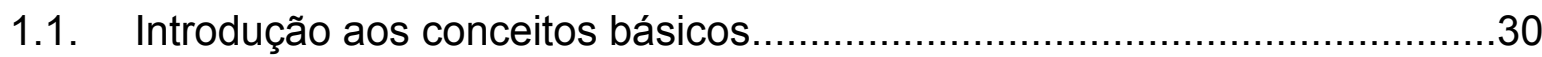

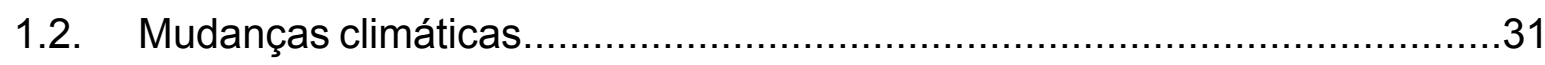

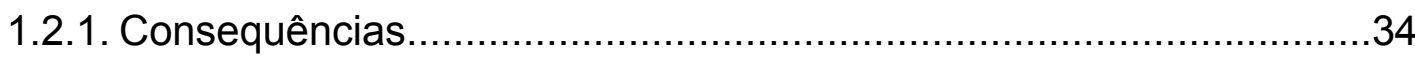

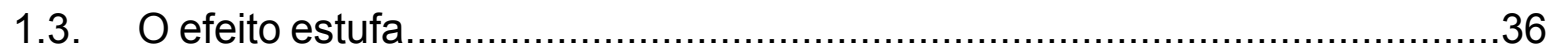

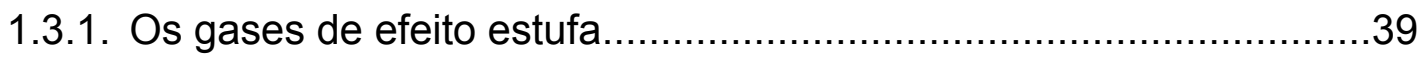

1.3.1.1. Clorofluorcarbono......................................................40

1.3.1.2. Hidrofluorcarbono................................................. 40

1.3.1.3. Perfluorcarbono......................................................... 40

1.3.1.4. Hexafluoreto de enxofre...........................................41

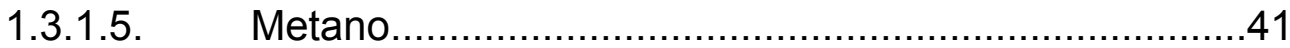

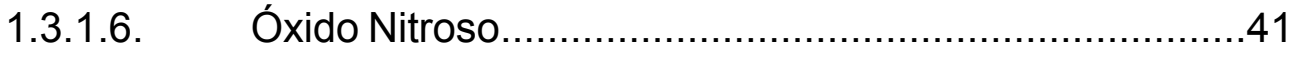

1.3.1.7. Dióxido de Carbono.....................................................42

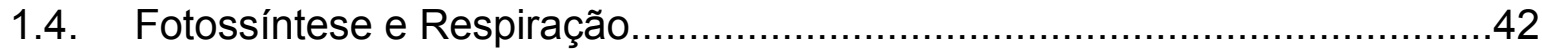

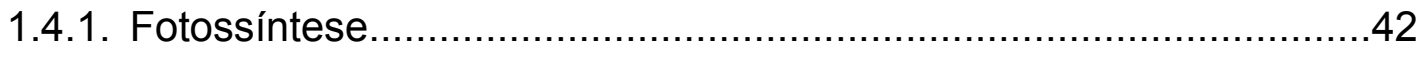




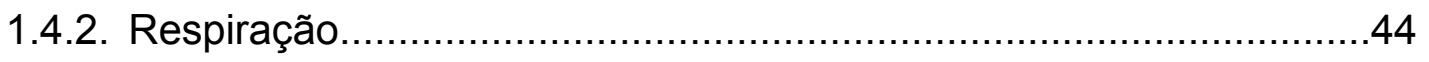

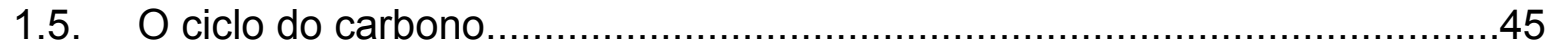

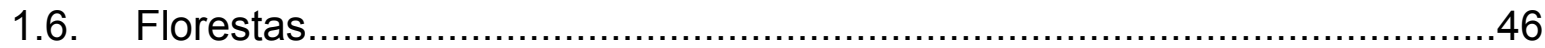

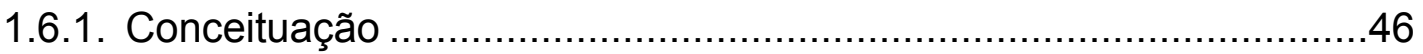

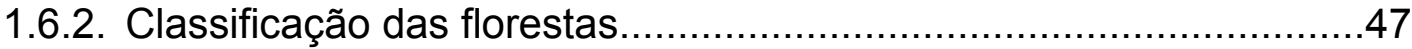

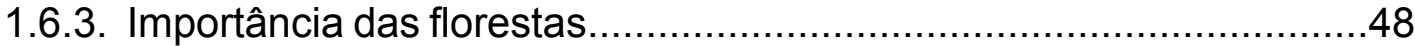

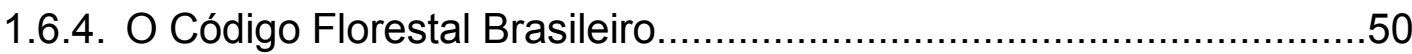

1.6.5. Programa Nacional de Florestas..............................................52

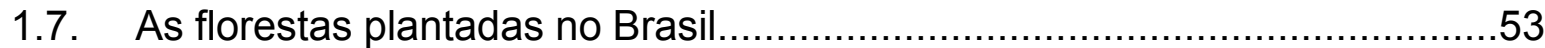

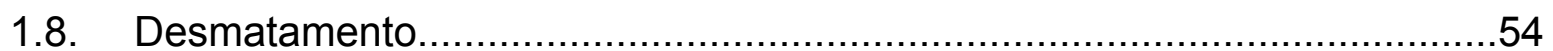

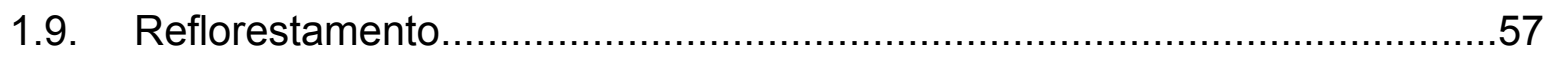

1.9.1. Projetos de reflorestamento no Brasil.......................................58

\section{CAPÍTULO II}

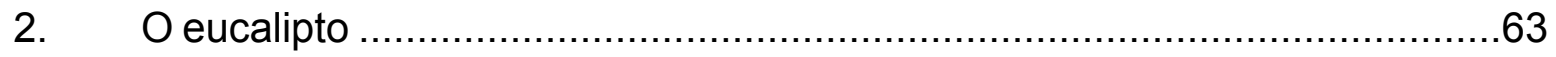

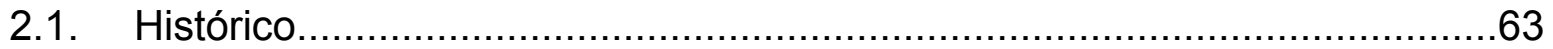

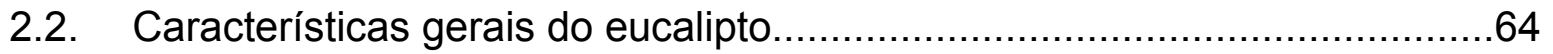

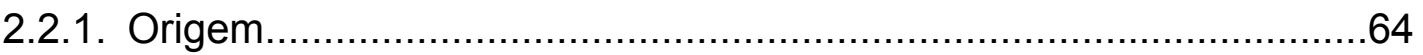

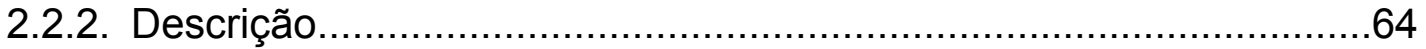

2.2.3. Classificação do gênero Eucalyptus dentro do Reino Vegetal..........65

2.2.4. Especificações técnicas....................................................................66

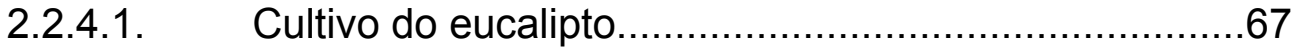

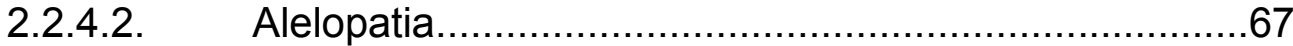

2.2.4.3. Consumo de água....................................................68

2.2.4.4. Biodiversidade.....................................................68

2.2.4.5. Pragas e

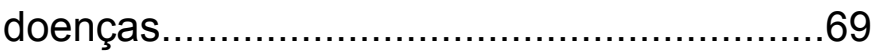

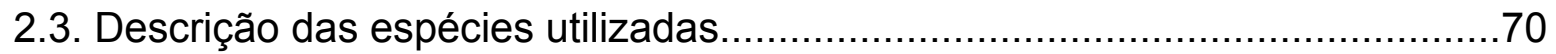

2.3.1. Eucalyptus grandis Hill ex-Maiden............................................70

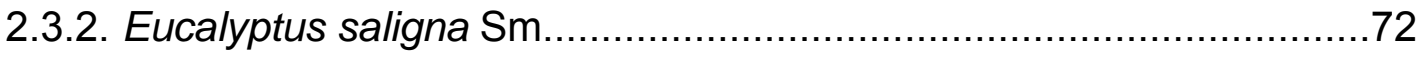




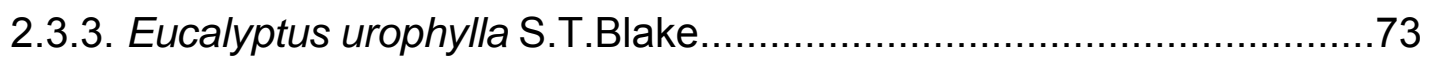

2.4. Vantagens e desvantagens da cultura de eucalipto.................................74

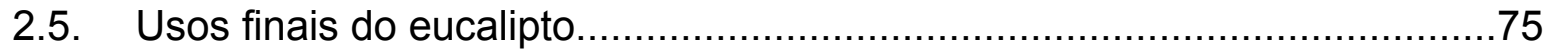

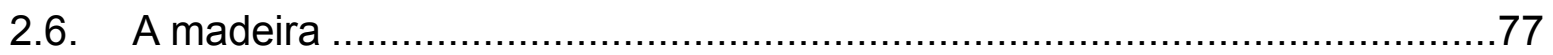

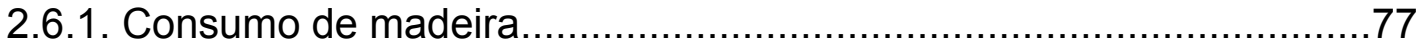

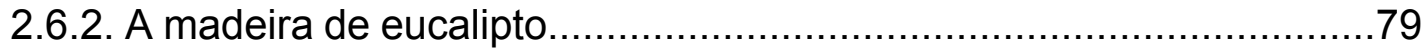

2.6.2.1. Constituição química da madeira de eucalipto.......................80

2.6.2.2. Rendimento da madeira serrada..........................................81

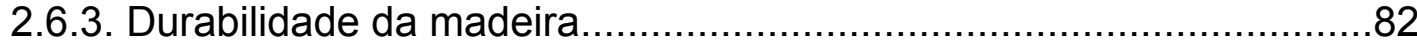

2.7. Produção nacional, mundial e importância da cultura.................................85

\section{CAPÍTULO III}

3. As discussões sobre as mudanças climáticas..........................................89

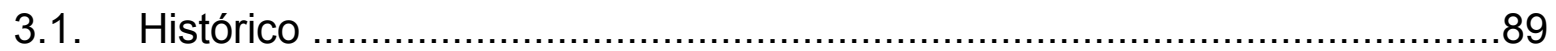

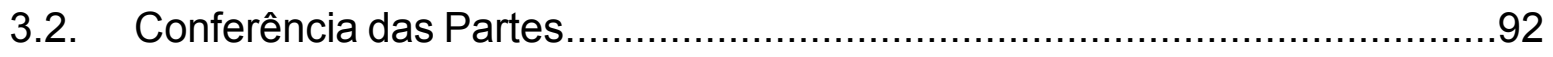

3.2.1. Próximas Conferências das Partes................................................95

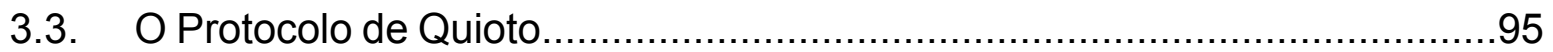

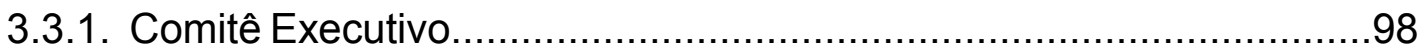

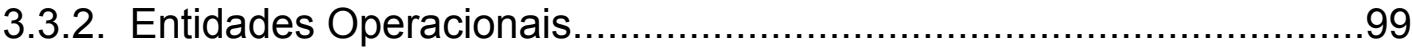

3.3.3. Comissão Interministerial de Mudança Global do Clima.................101

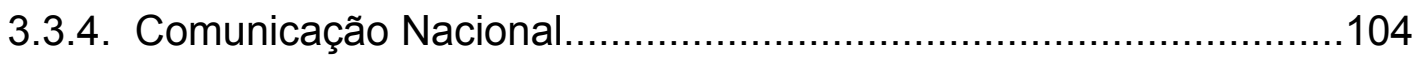

3.3.5. Adaptação, Construção de Capacidade e Transferência

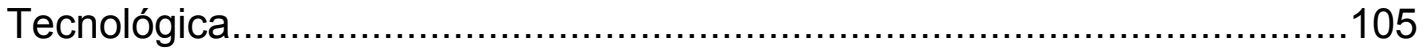

3.3.6. Mecanismo Financeiro...........................................................106

3.4. Mecanismos de Flexibilização.............................................................108

3.4.1. Implementação Conjunta..........................................................109

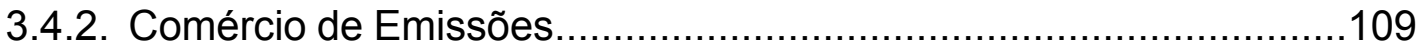

3.4.3. Mecanismo de Desenvolvimento Limpo.....................................110

3.5. Uso da terra, Mudança do uso da terra e Reflorestamento.......................112

3.6. Certificados de Redução de Emissões..................................................113 


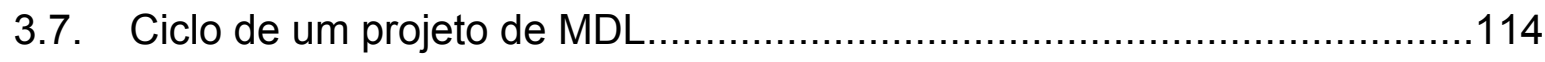

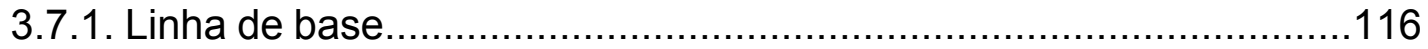

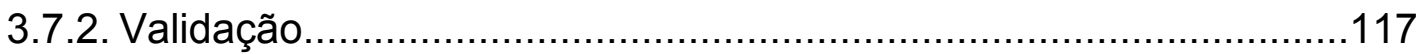

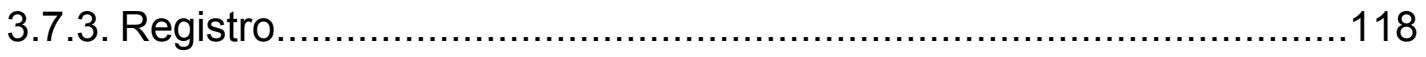

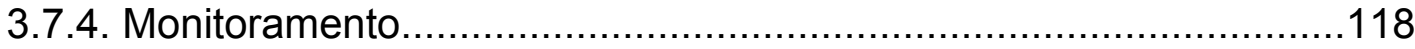

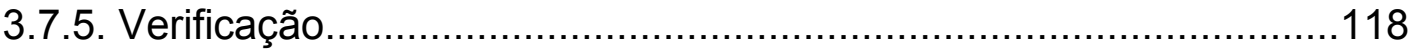

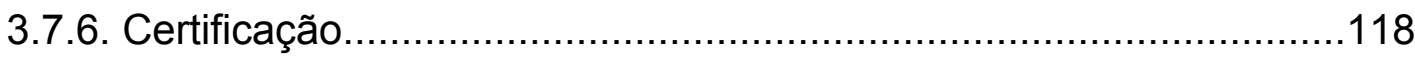

3.7.8. Emissão do certificado.........................................................118

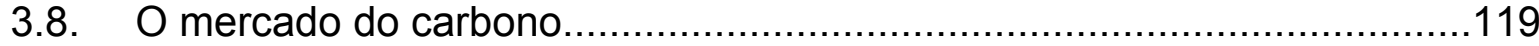

3.9. Quantificação do carbono em uma floresta de eucalipto...........................120

\section{CAPÍTULO IV}

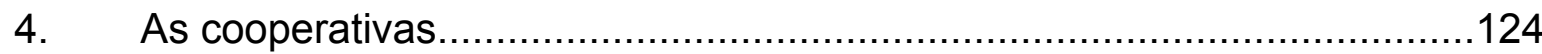

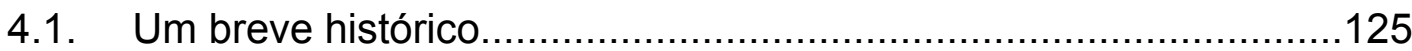

4.2. Conformações de uma cooperativa...........................................126

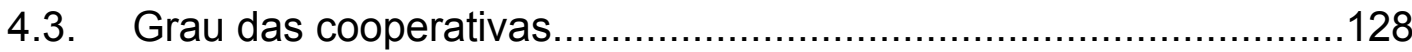

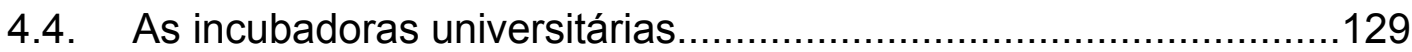

4.5. Cooperativas Florestais..........................................................131

4.6. Objetivos da cooperativa florestal..........................................132

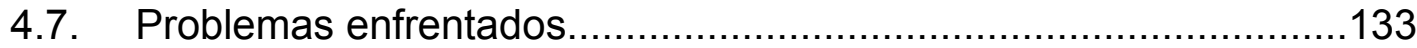

4.8. Vantagens de uma cooperativa florestal....................................136

\section{CAPÍTULO V}

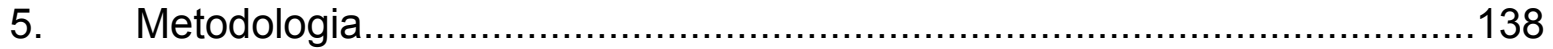

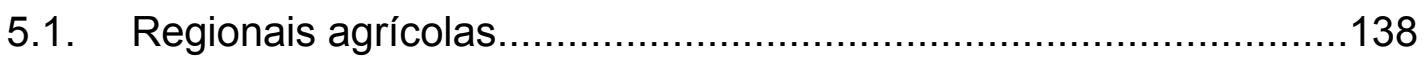

5.2. Área destinada ao projeto...................................................... 141

5.2.1. Área de Proteção Ambiental.............................................142

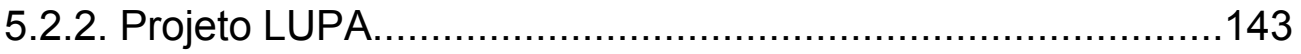




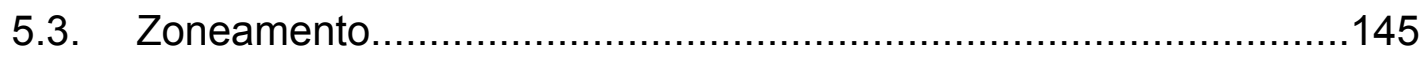

5.4. Custos relacionados à cultura............................................... 149

5.5. Metodologia da análise econômica..............................................151

5.6. Resultados e Discussão...........................................................153

\section{CAPÍTULO VI}

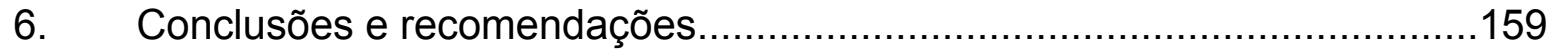

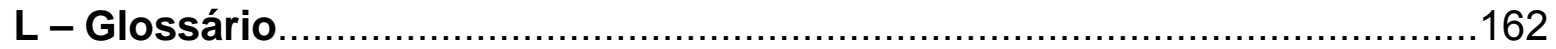

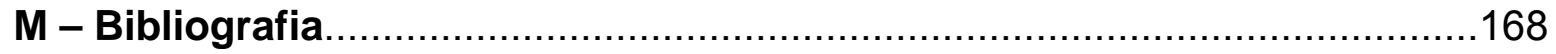

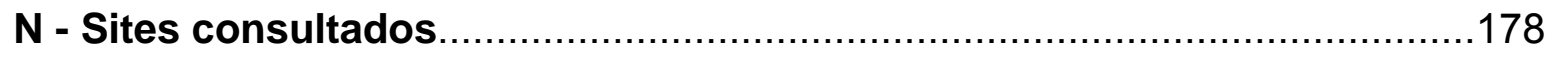

O - Relação de consultas e entrevistas realizadas........................................180

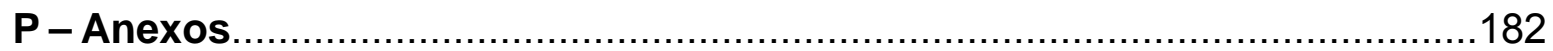




\section{B - Relação de quadros e tabelas utilizadas}

\section{CAPÍTULO I}

Tabela 1.1. - Contribuição das atividades na emissão dos gases de efeito estufa.

Tabela 1.2. - Maiores emissores de $\mathrm{CO}_{2}$ em 1990 (x 1.000 ton. de $\mathrm{CO}_{2}$ ).

Tabela 1.3. - Contribuição dos gases de efeito estufa na atmosfera.

\section{CAPÍTULO II}

Tabela 2.1. - Consumo de madeira industrial em toras no Brasil, em 1999 (x 1.000 $\left.m^{3}\right)$.

Tabela 2.2. - Comparação das características físicas e mecânicas de algumas espécies nativas e exóticas.

Tabela 2.3. - Área plantada de eucalipto no Brasil.

Tabela 2.4. - Área plantada de eucalipto no mundo.

\section{CAPÍTULO V}

Tabela 5.1. - Grau de instrução dos proprietários de Unidades de Produção Agropecuária (UPA) da regional agrícola de Botucatu.

Tabela 5.2. - Utilização do solo agropecuário brasileiro, de acordo com o censo agropecuário do IBGE - 1995/1996.

Tabela 5.3. - Disposição e aproveitamento de áreas da regional agrícola de Botucatu (1995/1996).

Tabela 5.4. - Relação das espécies de eucalipto que mais se adaptam ao cultivo na área relativa à regional de Botucatu.

Tabela 5.5. - Caracterização das regiões localizadas na regional agrícola de Botucatu de acordo com as condições bioclimáticas propostas por Golfari. 
Tabela 5.6. - Relação entre a área do projeto e os índices econômicos, considerando o emprego do MDL.

Tabela 5.7. - Relação entre a área do projeto e os índices econômicos, sem a participação dos créditos de MDL. 
C - Relação de figuras utilizadas

\section{CAPÍTULO III}

Figura 3.1. - Quadro institucional brasileiro para o gerenciamento de implementação dos assuntos referentes à conversão sobre mudança do clima.

Figura 3.2. - Ciclo de um projeto MDL.

\section{CAPÍTULO V}

Figura 5.1. - O estado de São Paulo e suas regionais agrícolas.

Figura 5.2. - Mapa da regional agrícola de Botucatu.

Figura 5.3. - Zoneamento Ecológico Esquemático para Reflorestamento no Brasil

- Estado de São Paulo. 


\section{D - Relação de conversões}

1 tonelada $(\mathrm{t})=1.000$ quilogramas $(\mathrm{kg})$

1 Megatonelada $(\mathrm{Mt})=1.000 .000$ ton. $10^{12} \mathrm{~g}$

1 Gigatonelada $(G t)=1.000 .000 .000$ ton .

1 hectare (ha) $=10.000$ metros quadrados $\left(\mathrm{m}^{2}\right)$

1 quilômetro quadrado $\left(\mathrm{km}^{2}\right)=100$ hectares (ha)

1 tonelada de carbono $=3.67$ toneladas de dióxido de carbono (ton. $\mathrm{CO}_{2}$ )

1 tonelada de dióxido de carbono $=0.273$ toneladas de carbono (ton. $C$ )

$1 \mathrm{st}=0,7 \mathrm{~m}^{3}=0,608$ ton. (conversão para madeira com casca)

$1 \mathrm{st}=0,61 \mathrm{~m}^{3}=0,577$ ton. (conversão para madeira sem casca) 


\section{E - Relação de espécies vegetais citadas e seus nomes científicos}

Achichá - Sferculia speciosa K. Sch.

Angelim-Pedra - Dizinia excelsa Ducke

Aroeira-do-Sertão - Schinus molle

Arroz - Oryza sativa L.

Aveia - Avena sativa L.

Braúna - Melanoxylon brauna Schott

Cabreúva - Myrocarpus frondosus Allemao

Cabreúva-Vermelha - Myroxylon peruiferum L.f.

Café - Coffea arabica

Capim-Braquiária - Brachiaria decumbens

Capim-Colonião - Panicus maximum Jacq.

Capim-Gordura - Melinis minutiflora

Capim-Jaraguá - Hyparrhenia rufa

Carvalho - Euplassa spp.

Caxeta - Tabebuia aassinioides

Cedrinho - Erisma uncinatum Warm.

Cedro - Cedrella spp

Cedrorama - Guarea guidonia (L.) Sleumer

Centeio - Secale cereale L.

Cereja - Prunus avium

Cevada - Hordeum vulgare L.

Curupixá - Rauwofia paraensis

Eucalipto - Eucalyptus globulus; Eucalyptus grandis; Eucalyptus saligna; Eucalyptus piluraris; Eucalyptus dunnii; Eucalyptus maculata; Eucalyptus cloeziana; Eucalyptus microcorys; Eucalyptus rostrata; Eucalyptus microteca; Eucalyptus hybrid; Eucalyptus urophylla; Eucalyptus tereticornis; Eucalyptus camaldulensis; Eucalyptus pellita.

Feijão - Phaseolus vulgaris

Freijó - Cordia goeldiana Huber

Fumo - Nicotiana tabacum Lin 
Garapa - Apuleia leiocarpa (Vog.)

Imbuia - Ocotes porosa (Nees) L. Barroso

Ipê - Tabebuia spp.

Ipê-Pardo - Tabebuia ochracea

Itapicuru-Amarelo - Goniorrhachis marginata Taubert.

Jacarandá - Jacaranda cuspidifolia Mart.

Jacarandá-Paulista - Machoerium villosum Vog.

Jatobá - Hymemaea courbarril Barks

Jequitibá - Cariniana estrellensis (Raddi) Kuntze

Laranja - Citrus cinensis Osbeck

Maçaranduba - Persea Pyrifolia Nees et Mart. Ex Nees

Milho - Zea mays L.

Mogno - Swietenia mahagoni L.

Pau-Brasil - Caesalpinia echinata Lam.

Pau-Ferro - Acacia acatehu Wild

Pau-Marfim - Balfourodendron riedelianum (Engl.) Engl.

Peroba - Aspidosperma polyneuron M. Arg

Pinheiro-do-Paraná - Araucaria angustifolia (Bert.) Kuntze

Pinho - ver Pinheiro-do-Paraná

Pinus - Pinus elliotti

Soja - Glicyne max L. Merril.

Sumaúma - Ceiba pentandra (L.) Gaertn.

Trigo - Triticum sativum Lam.

Virola-Rosa - Virola spp. 


\section{F - Relação de abreviaturas}

AAU - Assigned Amount Unit.

ABIMCI - Associação Brasileira da Indústria de Madeira Processada Mecanicamente.

ABIPA - Assoçiação Brasileira da Indústria de Painéis de Madeira.

ABRACAVE - Associação Brasileira de Florestas Renováveis.

$\mathrm{ACl}$ - Aliança Cooperativa Internacional.

AEB - Agência Espacial Brasileira.

APA - Área de Proteção Ambiental.

BAS - British Antarctic Service.

BRACELPA - Associação Brasileira de Celulose e Papel.

C - Carbono.

CAPES - Coordenação de Aperfeiçoamento Pessoal de Nível Superior.

CATI - Coordenadoria de Assistência Técnica Integral.

CDM - Clean Development Mechanism.

CEBDS - Conselho Empresarial Brasileiro para o Desenvolvimento Sustentável.

CEPEA - Centro de Estudos Avançados em Economia Aplicada.

CER (Ou CRE) - Certified Emission Reduction.

CFC - Clorofluorcarbono.

CO - Monóxido de carbono.

$\mathrm{CO}_{2}$ - Dióxido de carbono.

COP - Conference of Parts.

COPPE - Coordenação dos Programas de Pós-Graduação em Energia.

CPEF - Companhia Paulista de Estradas de Ferro.

CQMC - Convenção Quadro sobre Mudanças Climáticas.

CRE - Certificado de Redução de Emissões.

CSMC - Convenção sobre Mudança do Clima.

CSW - Central \& South West Corporation.

CVRD - Companhia Vale do Rio Doce.

DAP - Diâmetro à altura do peito.

EPA - Environment Protection Agency. 
ERU - Emissions Reduction Unit.

ESALQ - Escola Superior de Agricultura "Luiz de Queiroz".

EUA - Estados Unidos da América.

FAO - Food and Agriculture Organization.

FAPESP - Fundação de Amparo à Pesquisa do Estado de São Paulo.

FAR - First Assessment Report.

FBDS - Fundo Brasileiro de Desenvolvimento Sustentável.

FGV - Faculdade Getúlio Vargas.

FNMA - Fundo Nacional do Meio Ambiente.

FSC - Forest Stewardship Council.

$\mathbf{g} / \mathbf{c m}^{3}$ - Gramas por centímetro cúbico.

GEE - Gases de efeito estufa.

GEF - Global Environment Facility.

Gt. de C - Giga tonelada de carbono.

GWP - Global Warming Potential.

$\mathrm{H}_{2} \mathrm{O}$ - Água.

ha - Hectare.

HFC - Hidrofluorcarbono.

IBAMA - Instituto Brasileiro de Meio Ambiente e dos Recursos Naturais Renováveis.

IBGE - Instituto Brasileiro de Geografia e Estatística.

IEA - Instituto de Economia Agrícola.

IEE - Instituto de Eletrotécnica e Energia.

IF - Instituto de Física.

IMAZON - Instituto do Homem e do Meio Ambiente da Amazônia.

INC - Intergovernmental Negotiating Committe.

INPE - Instituto Nacional de Pesquisas Meteorológicas.

IPCC - Intergovernmental Pannel on Climate Change.

IPT - Intituto de Pesquisas Tecnológicas.

ITCP - Incubadora Tecnológica de Cooperativas Populares.

ITTO - Organização Internacional da Madeira Tropical.

km - Quilômetro. 
$\mathbf{k m}^{2}$ - Quilômetro quadrado.

LBA - Experimento de Grande Escala da Biosfera-Atmosfera da Amazônia.

LULUCF - Land Use, Land-Use Change and Forestry.

LUPA - Levantamento das Unidades de Produção Agropecuária.

m - Metro.

mm - Milímetro.

$\mathbf{m}^{3}$ _ Metros cúbicos.

MCT - Ministério das Ciências e Tecnologia.

MDF - Medium Density Fiberboard.

MDL - Mecanismo de Desenvolvimento Limpo.

MF - Mecanismo Financeiro.

MMA - Ministério do Meio Ambiente.

MOP - Merbers of Parts.

Mpa - Mega Pascal.

$\mathrm{N}_{\mathbf{2}} \mathbf{O}$ - Óxido nitroso.

$\mathbf{O}_{2}$ - Oxigênio.

$\mathrm{O}_{3}$ - Ozônio.

OMM (ou WMO) - Organização Meteorológica Mundial.

ONG - Organização não-governamental.

ONU - Organização das Nações Unidas.

PCF - Prototype Carbon Fund.

PEC - Parque Estadual do Cantão.

PFC - Perfluorcarbono.

PIB - Produto Interno Bruto.

PIPGE - Programa Interunidades de Pós-Graduação em Energia.

PNA - Parque Nacional do Araguaia.

PNF - Programa Nacional de Florestas.

PNUMA - Programa das Nações Unidas para o Meio Ambiente.

ppb - Partes por bilhão.

ppm - Partes por milhão.

PRONAF - Programa Nacional de Agricultura Familiar.

PSCIB - Projeto de Sequestro de Carbono da Ilha do Bananal e de seu Entorno. 
s.d. - Sem data.

SAR - Second Assessment Report.

SBS - Sociedade Brasileira de Silvicultura.

$\mathrm{SF}_{6}$ - Hexafluoreto de enxofre.

SOCODEVI - Societé de Coopération pour le Deévéloppement International.

SP - São Paulo.

SPVS - Sociedade de Pesquisa em Vida Silvestre e Educação Ambiental.

SRES - Special Report on Emissions Scenarios.

St - Estere.

STCP - STCP Engenharia de Projetos Ltda.

TIR - Taxa interna de retorno.

ton. - Tonelada.

ton. de C - Toneladas de carbono.

TNC - The Nature Conservancy.

UE - União Européia.

UFRJ - Universidade Federal do Rio de Janeiro.

UNCED - United Nations Conference on Environment and Development.

UNDP - United Nations Development Programme.

UNEP - United Nations on Environment Programme.

UNFCCC - United Nations Framework Convention on Climate Change.

UNGA - United Nation General Assembly.

UPA - Unidade de Produção Agropecuária.

USP - Universidade de São Paulo.

UV-B - Ultra-violeta B.

VPL - Valor presente líquido.

WMO - World Meteorological Organization.

WRI - World Resources Institute. 


\section{G - Resumo}

A questão das mudanças climáticas vem ganhando destaque e sendo mais discutida à medida que se caminha para a ratificação do Protocolo de Quioto.

No presente trabalho é analisada a viabilidade de um projeto de reflorestamento candidato ao Mecanismo de Desenvolvimento Limpo, mecanismo de flexibilização proposto pelo Protocolo que permite a participação brasileira. São discutidos aspectos favoráveis e desfavoráveis à implementação de um projeto florestal, nas condições atuais.

Para tal discussão, propõe-se uma atividade de reflorestamento com espécies do gênero Eucalyptus, administrada por uma cooperativa florestal, dentro da regional agrícola de Botucatu. Os objetivos principais desta atividade são a obtenção de madeira para fins de serraria e a comercialização de créditos de carbono referentes ao volume de madeira serrada.

Foram feitos cálculos de viabilidade econômica pela taxa interna de retorno (TIR) e pelo valor presente líquido (VPL) do projeto, com e sem o emprego do MDL. Verificou-se a viabilidade econômica nos dois casos, embora a diferença na receita não tenha sido considerável. Em projetos em que não há a participação do MDL, a TIR média foi de $7,0 \%$ para todas as áreas. Com a participação do MDL, houve uma variação da TIR de 6,2\% a 7,3\%, conforme as extensões das áreas adotadas e os preços pagos pela tonelada de carbono. Para pequenas áreas, o emprego do MDL pode inviabilizar o projeto.

As atividades florestais para fins de serraria mostraram um rendimento muito baixo para o MDL, pelo fato de apenas um décimo da produção total ser aceito para a comercialização dos créditos de carbono. 


\section{G - Abstract}

The issue of climate change wins relevance and brings controversy as the ratification of Kyoto Protocol approaches for most countries.

Present work analyses feasibility for a reforesting project candidate for the Clean Development Mechanism (CDM). CDM is a flexibilization mechanism proposed in the Protocol which allows Brazilian participation. Both favorable and unfavorable aspects are discussed for the implementation of a forest project under present conditions.

For the purpose of this discussion, an activity of reforestation based on trees of the Eucalyptus species, managed by a forest cooperative society, in the agricultural region of Botucatu. Main goals for such cooperative are obtainment of lumber and commercialization of carbon credits relative to the quantity of lumber produced.

Calculations for economic feasibility were carried out, producing the Internal Rate of Revenue (IRR) and the Present Net Worth (PNW), both under and out of CDM. Economical feasibility was confirmed for both cases, although difference between revenues was not considerable. For projects with no CDM participation, average IRR was 7,0 per cent for all area extents. With CDM participation, there was a rate range between 6,2 and 7,3 per cent, according to the extent of submitted areas, and prices paid for ton of carbon. For small areas, CDM adoption can turn the project unfeasible.

Forest activities for producing lumber showed low profitability for CDM, due to the fact that only one tenth of total production is accepted for commercialization of carbon credits. 
"Tentamos proteger a árvore, esquecidos de que é ela que nos protege."

Carlos Drummond de Andrade

\section{H - Introdução}

A queima de combustíveis fósseis (petróleo, carvão e gás natural) e as queimadas decorrentes dos desmatamentos, ocorridos com maior intensidade nos últimos 150 anos devido à Revolução Industrial e ao crescimento populacional, têm sido a maior causa de emissão de dióxido de carbono $\left(\mathrm{CO}_{2}\right)$ para a atmosfera (GOLDEMBERG, 1998). Este gás, juntamente com outros, como vapor d'água $\left(\mathrm{H}_{2} \mathrm{O}\right)$, metano $\left(\mathrm{CH}_{4}\right)$, óxido nitroso $\left(\mathrm{N}_{2} \mathrm{O}\right)$ e clorofluorcarbonos (CFC's), são conhecidos como gases de efeito estufa (GEE), que formam uma camada de gases na atmosfera. O efeito estufa é um fenômeno de ocorrência natural. Essa camada de gases tem um papel vital na maneira como a radiação solar interage com a Terra, fazendo com que a temperatura permaneça estabilizada e haja vida no planeta ${ }^{1}$ (SAGAN, 1982). De acordo com GOLDEMBERG (1998), a temperatura média da Terra sem os gases estufa seria de $15-20^{\circ} \mathrm{C}$ abaixo de zero. Portanto, essa camada exerce um papel benéfico: evita que haja grandes oscilações de temperatura e faz com que a radiação vinda do Sol seja em parte retida na superfície do planeta.

No presente trabalho, será dada ênfase ao dióxido de carbono $\left(\mathrm{CO}_{2}\right)$, gás estufa considerado de maior importância dentre os GEE, não só pelo volume de emissão, como também por ser parte de um ciclo onde é captado pelas plantas, em um processo físico-químico denominado fotossíntese. Através deste processo, os organismos fotossintetizantes ${ }^{2}$ retiram o dióxido de carbono da atmosfera e incorporam-no em seus compostos orgânicos, além de liberar oxigênio. Estes

1 A Lua, por não ter essa camada de gases atmosféricos, apresenta uma grande variação de temperatura, alcançando até $100^{\circ} \mathrm{C}$ durante o dia e chegando aos $200^{\circ} \mathrm{C}$ negativos durante a noite. 2 Plantas, fitoplânctons, algas marinhas e cianobactérias. 
compostos orgânicos formam a biomassa florestal, que será alvo de discussão do presente trabalho.

Desde a Revolução Industrial, houve um salto na concentração do dióxido de carbono na atmosfera, que passou de 285 ppm para 366 ppm. Entre 1850 e 1998, foram liberados para a atmosfera aproximadamente $405 \pm 60$ Gt. de C., sendo $67 \%$ provenientes da queima de combustíveis fósseis e $33 \%$ provenientes de terras agriculturadas ou modificadas pelo homem. Isso significou um acréscimo de $28 \%$ de dióxido de carbono na atmosfera (IPCC, 2001).

O volume de emissão desses gases tem sido maior do que aquele que a Terra pode absorver em seus ciclos naturais. Pesquisas desenvolvidas por equipes de cientistas de todo o mundo, como o IPCC, têm demonstrado que o acúmulo desses gases traz consequências danosas ao meio ambiente e ao homem. A principal delas é o aquecimento global e, em decorrência dele, o descongelamento de geleiras (que provocam o aumento do nível dos oceanos), a maior incidência de doenças tropicais, a desregulação climática, a perda e a migração de biodiversidade, entre outras.

Com as evidentes consequências do aquecimento global $^{3}$, houve um aumento sensível de interesse por discussões relacionadas às mudanças climáticas, principalmente a partir da década de 1980. Essas discussões levaram à criação de alguns tratados, que tinham como objetivo o combate das mudanças do clima.

O Protocolo de Quioto (de 1997), dentre os tantos tratados lançados a respeito do meio ambiente, foi o de maior importância por convocar os países de todo o mundo (em especial aqueles desenvolvidos) a uma redução na emissão dos gases de efeito estufa, sobretudo o dióxido de carbono, com cotas estabelecidas e prazos de redução.

\footnotetext{
${ }^{3} \mathrm{O}$ problema do aquecimento global vem sendo apontado há cerca de 20 anos como uma questão de importância e peso dentro do quadro ambiental global. O terceiro relatório do Painel Intergovernamental de Mudanças Climáticas, divulgado em 2001, reforça a afirmativa de que as atividades humanas têm grande responsabilidade no problema do aquecimento global.
} 
Foi criada uma política de mercado de carbono, envolvendo as questões ambientais. Essa política vem ganhando força à medida que se caminha para a ratificação do Protocolo de Quioto. Uma das maneiras de se reduzir as emissões de GEE, responsáveis em grande parte pelas mudanças climáticas, é através da comercialização de créditos de carbono. Esses créditos, comercializados na forma de certificados de redução de emissões, são provenientes de projetos de sequestro de carbono, considerados "projetos limpos", por reduzirem de alguma forma as emissões desses gases. Dentro do Protocolo, foram estabelecidos mecanismos de flexibilização (Implementação Conjunta, Comércio de Emissões e Mecanismo de Desenvolvimento Limpo), que têm o objetivo de viabilizar a redução da emissão dos gases estufa dos países desenvolvidos, relacionados no Anexo-I do Protocolo. Dentre estes mecanismos, o Mecanismo de Desenvolvimento Limpo é o único que pode ser aplicado no Brasil (conforme será descrito adiante), trazendo benefícios sociais, ambientais e econômicos à região envolvida.

Atualmente, no Brasil, empresas como a Peugeot, Texaco, CVRD e Petrobrás, têm possibilidade de empreender projetos de reflorestamento de grande escala visando uma futura obtenção de créditos de MDL. Além disso, essas empresas possuem capital para custear atividades de auditoria e certificação ambiental ("selo verde"), essenciais para a aceitação e uma boa colocação do projeto diante dos moldes do MDL e do mercado de carbono. Estas atividades são muitas vezes onerosas para projetos menores que não envolvem empresas ou participação externa de instituições financeiras.

A participação no MDL deve ser voluntária e pode ser de iniciativa estatal ou privada. É possível, assim, que um grupo de agricultores esteja disposto a montar um projeto de reflorestamento visando sequestro de carbono e, a partir deste, comercializar certificados dentro do MDL. Participam do projeto os agricultores que dispuserem de área para reflorestamento, mão-de-obra e suporte técnico para o emprego do projeto. As cooperativas trazem a vantagem de garantir uma maior homogeneidade na condução da cultura, na obtenção do produto, na 
melhor organização e no ganho de escala da produção. Fortalecidos por cooperativas, esses agricultores poderão obter uma nova fonte de renda com os projetos de reflorestamento.

A utilização do eucalipto para madeira serrada é uma contribuição do projeto ao meio ambiente, onde o produto final tem um emprego mais nobre, ao ser usado no setor de movelaria ou construção civil. O carbono ficaria retido na madeira por um período de tempo maior, se comparado com o produto final destinado aos setores de celulose, papel ou carvão vegetal.

O presente trabalho está dividido em seis capítulos: O primeiro capítulo dará ênfase à discussão do aquecimento global e suas consequências para o meio ambiente. Como o estudo trata de uma atividade de reflorestamento, serão abordados os conceitos de fotossíntese, respiração e ciclo do carbono, prérequisito para o entendimento dos caminhos do carbono em uma espécie vegetal, além do desmatamento e reflorestamento, atividades largamente empregadas pelo homem.

O segundo capítulo irá tratar da cultura do eucalipto e sua importância para - Brasil e para o mundo, bem como da sua representatividade para o setor florestal, através de seus produtos. A madeira serrada, suas finalidades e importância também serão assuntos apreciados, pois trata-se do produto obtido no final do ciclo produtivo do eucalipto e tema do presente estudo.

O terceiro capítulo abrangerá o histórico das discussões travadas acerca das mudanças climáticas até o desenvolvimento do Protocolo de Quioto. 0 Protocolo será descrito, discutido e, mais especificamente, o Mecanismo de Desenvolvimento Limpo, alvo do presente projeto. Será apresentado o ciclo de um projeto para a participação no MDL e a política ambiental que envolve o mercado. 
O quarto capítulo tratará da conceituação, funcionamento e emprego das cooperativas. Será feito um elo para participação de cooperativas em projetos de reflorestamento e sua aplicação no MDL.

O quinto capítulo será o cerne do trabalho e tratará da escolha da região e da área a serem utilizadas para o estudo, além do cálculo das variáveis determinantes da viabilidade econômica do projeto. Será feita a discussão de suas variáveis.

O sexto capítulo, de caráter conclusivo, trará o arremate da discussão, sugestões e direcionamentos para futuros trabalhos, levantando a questão da viabilidade do emprego do MDL para projetos de reflorestamento com finalidade para madeira serrada, que sejam geridos regionalmente por cooperativas.

\section{I - Objetivo}

Será analisada, no presente trabalho, a viabilidade de um projeto teórico de reflorestamento homogêneo com espécies de eucalipto, tendo como finalidade a participação no Mecanismo de Desenvolvimento Limpo ${ }^{4}$ (MDL). Dentro deste projeto de reflorestamento, visa-se o aproveitamento de madeira serrada como produto final e a comercialização de Certificados de Redução de Emissões ${ }^{5}$ (CRE's), no âmbito do MDL, proposto pelo Protocolo de Quioto, a ser ratificado ${ }^{6}$ possivelmente no ano de 2002.

O reflorestamento deve ocorrer em áreas que não sejam conflitivas com aquelas que já possuam culturas instaladas - como as culturas perenes, semiperenes, anuais - ou em regiões de pastagem. O ciclo adotado para o projeto é de 14 anos, tempo mínimo necessário para se obter madeira para fins de serraria.

\footnotetext{
${ }^{4}$ Este mecanismo de flexibilização será descrito no capítulo III.

${ }^{5}$ Os CRE's são a forma de comercialização do carbono retido ou evitado nos projetos de MDL.

${ }^{6}$ Para que se transforme em lei, o protocolo deve ser aceito por 55 países que representem pelo menos $55 \%$ das emissões de GEE.
} 
O projeto é proposto para uma região agrícola na qual as atividades sejam geridas por cooperativa também de alcance local; estas devem se encarregar da supervisão na instalação da cultura, transação dos CRE's e auxílio na venda do produto final. A adoção de critérios padronizados e regionalizados para condução da cultura visa a obtenção de um produto final (madeira serrada) mais homogêneo e uma aceitação maior no mercado mundial de carbono, no momento da venda dos certificados. Para uma melhor visualização do exercício, será tomada como estudo de caso a regional agrícola de Botucatu, localizada no estado de São Paulo. Essa região é um pólo representativo dentro do setor florestal brasileiro, por abarcar $2 \%$ de todo o eucalipto plantado no país e possuir indústrias florestais na região.

Objetiva-se com a atividade de reflorestamento uma série de melhorias ambientais, sociais e econômicas de impacto regional, fortalecendo-se o quadro geral da região agrícola envolvida. Os indicadores de melhoria no aspecto ambiental são a diminuição da erosão nos solos devido à maior cobertura vegetal, a ciclagem de nutrientes, além do sequestro do $\mathrm{CO}_{2}$ atmosférico e produção de $\mathrm{O}_{2}$, entre outros; no aspecto social, são a geração de empregos e a maior relação entre os cooperados; no aspecto econômico, o giro de capital com o emprego do projeto e a contribuição para o aquecimento local do comércio de mudas, defensivos e do produto final, a madeira serrada.

Este projeto, apesar de limitado à área de Botucatu, pode ser facilmente expandido e implementado em outras regionais agrícolas e outros estados brasileiros onde o eucalipto apresente precedentes de cultivo e desenvolvimento. A possibilidade de adaptação do projeto em outras regiões é devida à aplicação de uma metodologia simples, que será descrita adiante ${ }^{7}$.

\footnotetext{
${ }^{7}$ A descrição e discussão da metodologia serão feitas no Capítulo V.
} 


\section{J - Hipótese}

A hipótese que se tem dentro do tema é a de que, através da organização dos agricultores dentro de cooperativas, torne-se viável a participação destes em projetos florestais de MDL com espécies de eucalipto para fins de madeira serrada. As cooperativas têm a função de fortalecer o trabalho dos agricultores cooperados e oferecer uma maior homogeneidade ao produto, além de garantir uma intermediação do projeto com o mercado de carbono. Tal atividade poderá gerar, além da fonte de renda já existente, que é a madeira serrada, uma nova fonte de renda a esses agricultores através da comercialização dos CRE's, aumentando assim a renda por área e, consequentemente, por propriedade.

Além disso, com a implantação e expansão do projeto, espera-se que haja uma diminuição da pressão sobre o restante das matas naturais, possibilitando uma substituição gradativa e crescente no emprego de madeiras nativas pela madeira proveniente de atividades de reflorestamentos, como é o caso do eucalipto. O plantio deve ocorrer em áreas consideradas inaproveitáveis (áreas declivosas, pedregosas, entre outras), de modo que não haja conflito com áreas tomadas por florestas nativas ou atividades agropecuárias. Além de respeitar as áreas que já desenvolvam alguma atividade, este projeto trará uma contribuição ambiental.

\section{K - Justificativa}

O presente projeto tem um foco político, social e ambiental. Envolve questões relacionadas às mudanças climáticas e suas discussões, assunto de extrema importância e de grande atualidade. Levanta a proposta do emprego de cooperativas florestais para o fortalecimento de agricultores e da participação destes em um tratado mundial, que traz benefícios ambientais, através da comercialização de certificados. Promove o plantio em escala de uma espécie de 
rápido crescimento, que pode ser usada na substituição de espécies nativas para fins de serraria.

Existem projetos de reflorestamento no Brasil, alguns deles envolvendo o gênero Eucalyptus. São projetos de grandes empresas, que aguardam a ratificação do Protocolo de Quioto e a definição da regulamentação da metodologia de atividades florestais para o MDL, para uma possível comercialização do carbono sequestrado em suas formações florestais. 


\section{Capítulo I}

Este capítulo tratará do histórico das questões relacionadas ao aquecimento global, de que forma ocorreram as alterações climáticas pelas quais estamos passando e como o homem pode reverter ou retardar essa situação (as questões políticas relacionadas à mudança do clima serão discutidas no Capítulo III). Serão abordados os conceitos de efeito estufa, fotossíntese, respiração e ciclo do carbono, ciclo este que engloba os processos de fotossíntese e respiração.

Serão discutidos ainda o desmatamento e o desgaste provocado no meio ambiente por este processo, o reflorestamento e a gama de benefícios que esta última atividade pode proporcionar. Os conceitos de florestas e as florestas plantadas são ainda outros tópicos tratados no presente capítulo.

A discussão destes conceitos é um pré-requisito para o entendimento da questão multilateral que envolve a área técnica da cultura de florestas (mais conhecida como silvicultura) e os processos que envolvem a política de comercialização de créditos de carbono. 


\section{Mudanças climáticas e o meio ambiente}

\subsection{Introdução aos conceitos básicos}

É interessante que sejam esclarecidos alguns conceitos básicos que serão utilizados com frequência no decorrer deste trabalho. As definições transcritas que se seguem foram extraídas da Convenção sobre Mudança do Clima (CSMC) de 1992, documento que antecedeu o Protocolo de Quioto e que reconhece oficialmente o problema das mudanças climáticas. Seguem-se as principais definições:

Mudança do clima - "Significa uma mudança de clima que possa ser direta ou indiretamente atribuída à atividade humana que altere a composição da atmosfera mundial e que se some àquela provocada pela variabilidade climática natural observada ao longo de períodos comparáveis."

Gases de efeito estufa - "Significa os constituíntes gasosos da atmosfera, naturais e antrópicos, que absorvem e reemitem radiação infravermelha."

Emissões - "Significa a liberação de gases de efeito estufa e/ou seus precursores na atmosfera numa área específica e num período determinado."

Reservatórios - "Significa um componente ou componentes do sistema climático no que fica armazenado um gás de efeito estufa ou um precursor de um GEE."

Sumidouro - "Significa qualquer processo, atividade ou mecanismo que remova um gás de efeito estufa, um aerossol ou um precursor de um GEE da atmosfera."

Fonte - "Significa qualquer processo ou atividade que libere um gás de efeito estufa, um aerossol, ou um precursor de GEE na atmosfera." 


\subsection{Mudanças climáticas}

Com o advento da Revolução Industrial houve- um sensível aumento na emissão de gases efeito estufa devido à substituição de trabalho manual por máquinas de produção em grande escala. A queima de combustíveis fósseis (petróleo, carvão e gás natural) e as queimadas decorrentes dos desmatamentos serviram e ainda servem ao homem em suas necessidades e para seu desenvolvimento. Mas, ao mesmo tempo, causaram alguns danos ao meio ambiente. Esse agravamento parece estar fortemente atrelado ao desenvolvimento econômico e ao consumo humano e o meio ambiente começa a dar seus primeiros sinais de saturação.

As atividades que contribuem para o aumento das concentrações de GEE podem ser observadas na tabela 1.1 .

Tabela 1.1. - Contribuição das atividades na emissão dos gases de efeito estufa

\begin{tabular}{|c|c|}
\hline Atividade & Contribuição (\%) \\
\hline Energia & 57 \\
\hline CFC & 17 \\
\hline Agricultura & 14 \\
\hline Desmatamento & 9 \\
\hline Indústria & 3 \\
\hline TOTAL & $\mathbf{1 0 0}$ \\
\hline
\end{tabular}

Fonte: GOLDEMBERG (1995) apud MCT.

Na tabela 1.1., pode-se observar que mais da metade da contribuição dos GEE dá-se no setor de energia, onde é feita a queima dos combustíveis fósseis (petróleo, carvão e gás natural) para as finalidades de transporte e obtenção de energia elétrica. Em segundo lugar nas contribuições, está o gás CFC, que já vem sendo controlado através da criação do Protocolo de Montreal (vide ítem 3.3.). As atividades relacionadas à agricultura vêm logo em seguida, com a liberação de metano para a atmosfera: o cultivo de arroz e a atividade pecuária estão entre as atividades que emitem metano na agricultura. $O$ desmatamento contribui bastante para a emissão dos gases de efeito estufa, através das queimadas. Em último 
lugar, na contribuição dos GEE para a atmosfera, estão as indústrias. Deve-se atentar que as indústrias estão atreladas à produção de energia e fabricação dos gases CFC.

A tabela 1.2. indica os maiores emissores de dióxido de carbono em 1990.

Tabela 1.2. - Maiores emissores de $\mathrm{CO}_{2}$ em 1990 (x 1000 ton. de $\mathrm{CO}_{2}$ ).

\begin{tabular}{|c|c|c|c|}
\hline Parte Anexo I & Emissões de $\mathbf{C O}_{\mathbf{2}}$ & \multicolumn{2}{|c|}{ Participação (\%) sobre } \\
\hline- & - & Total Anexo I & Total global \\
\hline EUA & 4.819 .166 .00 & 34.5 & 21.62 \\
\hline Rússia & 3.708 .734 .33 & 26.55 & 16.64 \\
\hline Japão & 1.071 .444 .00 & 7.67 & 4.81 \\
\hline Alemanha & 1.012 .443 .00 & 7.25 & 4.54 \\
\hline Reino Unido & 563.647 .33 & 4.04 & 2.53 \\
\hline Canadá & 425.054 .67 & 3.04 & 1.91 \\
\hline Itália & 399.142 .33 & 2.86 & 1.79 \\
\hline Polônia & 347.838 .33 & 2.49 & 1.56 \\
\hline Austrália & 266.203 .67 & 1.91 & 1.19 \\
\hline Outros & 1.354 .931 .67 & 9.7 & 6.08 \\
\hline Total Anexo I & 13.968 .605 .33 & 100 & 62.66 \\
\hline Total não Anexo I & 8.322 .908 .00 & - & 37.34 \\
\hline Total & $\mathbf{2 2 . 2 9 1 . 5 1 3 . 3 3}$ & - & $\mathbf{1 0 0}$ \\
\hline
\end{tabular}

Fonte: Brasil Energia, 2002.

Nesta tabela, introduz-se um conceito novo, que é o dos países do Anexo I, que será discutido com maior profundidade no ítem 3.1. Os países do Anexo I são aqueles que têm o compromisso de reduzir as suas emissões de GEE. Pode-se observar através da tabela 1.2. que os EUA, maiores emissores de gases de efeito estufa do planeta, representam $21,62 \%$ do total global emitido. Dentro da relação dos países do Anexo I, os EUA representam mais de $1 / 3$ das emissões relacionadas. Sabe-se que de 1990 até os dias atuais, as emissões deste país aumentaram em 11\% (NOVAES, 2002) e que hoje representam 1/4 das emissões globais de GEE. Apesar de tal responsabilidade, os EUA não abriram mão de seu quadro atual e se negaram, até o momento, a ratificar o Protocolo. Outros países desenvolvidos, como a Rússia, Japão e Alemanha, também relacionados no Anexo I, são, na sequência, os maiores emissores de $\mathrm{CO}_{2}$. Ao todo, os países 
desenvolvidos representam praticamente $2 / 3$ das emissões de dióxido de carbono, ficando a terça parte restante, atribuída às emissões dos países em desenvolvimento.

De acordo com o relatório do Grupo I $^{8}$ do IPCC, "as emissões de gases estufa e aerossóis devidas às atividades humanas continuam a alterar a atmosfera de maneira que se espera que o clima seja afetado".

Análises feitas das bolhas de ar nas camadas de gelo na Groelândia e Antártida dão uma idéia razoável das variações de concentração de $\mathrm{CO}_{2}$ desde a última era glacial. As bolhas de ar encontradas no gelo evidenciam que a camada atmosférica está sendo alterada de forma muito rápida. Os gases estufa são liberados em uma quantidade maior do que aquela que os ciclos biogeoquímicos da Terra conseguem absorver. Não há precedentes da atual taxa de incremento desse gás nos últimos 20.000 anos (IPCC, 2001).

Cerca de 3/4 das emissões antropogênicas de dióxido de carbono para a atmosfera nos últimos 20 anos são decorrentes da queima de combustíveis fósseis. A quarta parte restante é predominantemente devida à mudança do uso do solo, mais precisamente às queimadas provenientes de desmatamentos (IPCC, 2001). Segundo GOLDEMBERG (1998), a utilização atual de combustíveis fósseis contribui com $6 \mathrm{Gt}$. de $\mathrm{C}$ anuais e o desmatamento com 1,6 Gt. de C para o agravamento do efeito estufa.

Como já foi dito, os EUA são os maiores emissores de combustíveis fósseis, com $25 \%$ das emissões mundiais e uma média de emissão de 6 toneladas por habitante por ano. O Brasil, que emite 0,5 tonelada por habitante por ano, ocupa o $20^{\circ}$ lugar no ranking das emissões mundiais, com cerca de 70 milhões de toneladas anuais de carbono (GOLDEMBERG, 2001a.). Pode-se observar no ítem

\footnotetext{
${ }^{8}$ O IPCC tem três grupos de trabalho: Grupo I - Avalia os aspectos científicos do sistema climático e das mudanças climáticas: Grupo II - Avalia a vulnerabilidade sócio-econômica e natural dos sistemas para as mudanças climáticas, consequências positivas e negativas das mudanças
} 
1.8., que o Brasil torna-se um dos maiores emissores de $\mathrm{CO}_{2}$ do mundo, se forem contabilizadas as queimadas da floresta Amazônica.

\subsubsection{Consequências}

Devido ao aumento de concentração desses gases, um fenômeno natural conhecido como efeito estufa vem se agravando e trazendo consigo um aumento da temperatura média global. A média de temperatura da superfície terrestre (temperatura do ar acima da terra e temperatura da superfície dos oceanos) sofreu um acréscimo de $0,6^{\circ} \mathrm{C}$ no século XX. Segundo o IPCC (2001), é muito provável ${ }^{9}$ que, em níveis globais, a década de 1990 tenha sido a mais quente e o ano de 1998, o mais quente da década, desde 1861, quando se iniciaram medidas de temperatura por instrumentação. O IPCC afirma ainda que é muito provável que tenha havido uma redução na ocorrência de temperaturas extremamente baixas, com um pequeno acréscimo na frequência de temperaturas extremamente altas.

Consequências deletérias são esperadas com o aquecimento global, como uma maior propagação de doenças tropicais, derretimento das calotas polares, aumento do nível médio dos oceanos, migração e extinção de biodiversidade, entre outras, afetando direta e indiretamente o homem e os ecossitemas de maneira irreversível. Algumas delas já podem ser observadas.

Dados de satélite indicam que é muito provável que já tenha havido um decréscimo de cerca de $10 \%$ nas camadas de gelo, desde o final dos anos 60 . No verão e primavera do hemisfério Norte tem havido um decréscimo do gelo do mar entre 10 e 15\%, desde 1950 .

climáticas e opções para a sua adaptação; Grupo III - Avalia as opções para limitar as emissões de gases de efeito estufa.

${ }^{9}$ De acordo com o IPCC, muito provável, é uma estimativa utilizada para indicar o grau de certeza do corpo de cientistas diante de uma informação. De acordo com o julgamento do IPCC, muito provável retrata um grau de certeza de 90 a 99\%. 
A plataforma Larsen, uma geleira gigante (sete vezes maior que Cingapura), com uma área de $3.250 \mathrm{~km}^{2}$, desintegrou-se por conta do aquecimento global. A previsão foi feita há quatro anos pelo grupo pertencente ao British Antarctic Service (BAS), que se surpreendeu com a velocidade desta desintegração. A península Antártica aqueceu $2,5^{\circ} \mathrm{C}$ nos últimos 50 anos, mais que em qualquer outra parte do globo (REUTERS, 2002).

Dados obtidos de medidas dos níveis das marés indicam que houve um aumento de ordem global no nível dos oceanos, em decorrência do derretimento das geleiras. $O$ aumento durante o século $X X$ foi entre 0,1 e 0,2 metros. Esta elevação do nível dos oceanos deve causar um deslocamento da população litorânea, provocando, no mínimo, uma perturbação de ordem econômica. Estimase que o número de pessoas afetadas a médio e longo prazo, seja de 1 bilhão. As áreas impactadas serão as regiões costeiras e países insulares, como Holanda, Bangladesh e cidades como Boston e Nova York (MONZONI, 2000).

Os oceanos também sofreram um aumento de temperatura desde a década de 1950, quando já se verificavam as temperaturas da sub-superfície dos oceanos com instrumentação (IPCC, 2001).

É muito provável que as precipitações tenham aumentado de 0,5 a $1 \%$ por década no século $X X$ nos continentes do hemisfério Norte e que esse incremento tenha sido de 0,2 a $0,3 \%$ por década nas áreas tropicais $\left(10^{\circ} \mathrm{N}\right.$ a $\left.10^{\circ} \mathrm{S}\right)$. É também provável que as precipitações tenham decrescido nas áreas sub-tropicais do hemisfério Norte $\left(10^{\circ} \mathrm{N}\right.$ a $\left.30^{\circ} \mathrm{N}\right)$ durante o século XX em $0,3 \%$ por década. Esperase que haja o aumento da precipitação sobre os continentes em $1 \%$ e que haja um declínio da precipitação sobre as áreas tropicais (id.).

O aumento global da temperatura também pode causar graves danos aos ecossistemas e à biodiversidade do planeta. Um deles é a migração da fauna e da flora em virtude das incompatibilidades de adaptação ao novo clima. Com o aquecimento global, o deslocamento das espécies ocorre da linha do Equador 
para os pólos e de baixo para cima (em relação à altitude). Segundo a World Resources Institute (WRI s.d.), a cada incremento de $1^{\circ} \mathrm{C}$ na temperatura média da Terra, ocorrerá um deslocamento no limite de tolerância das espécies terrestres de $125 \mathrm{Km}$ dos pólos ou, verticalmente, pode determinar uma ascenção (ou deslocamento) da biodiversidade em 150 metros nas montanhas. Ainda de acordo com a WRI, muitas espécies não têm condições de redistribuição com a necessária rapidez para adaptação às mudanças previstas e há probabilidade de que se produzam consideráveis alterações na estrutura e no funcionamento dos ecossistemas. Como exemplo do deslocamento da biodiversidade, pode-se citar o das borboletas da Europa e dos EUA, na qual a zona de distribuição de 39 espécies se deslocou até $200 \mathrm{~km}$ para o norte. No Alasca, os arbustos expandiram-se para as zonas geladas, livres de arbustos. Um terceiro exemplo desta migração forçada é o de peixes e plânctons na Costa da Califórnia, que invadiram os ecossistemas de águas temperadas e frias (ANGELO, 2002b.).

Uma outra consequência danosa ao meio ambiente é a do branqueamento dos recifes de coral. Em decorrência do aumento de temperatura da água oceânica, as algas microscópicas, que dão cor aos corais, morrem ou migram, deixando-os brancos. Este problema tem sido observado desde 1979. Em 1998, ano com as maiores temperaturas já registradas, $16 \%$ dos corais de todo o mundo perderam a cor (id.).

\subsection{O efeito estufa}

A atmosfera que conhecemos, e que nos garante vida na Terra, é constituída de $78 \%$ de nitrogênio, $21 \%$ de oxigênio e $1 \%$ de outros gases como o dióxido de carbono, argônio, hélio, hidrogênio e outros (GOLDEMBERG, 1989). Alguns destes gases constituintes da atmosfera são responsáveis pelo efeito estufa. 
O efeito estufa é um fenômeno natural que possibilita vida na Terra. Os principais gases constituintes da camada estufa são o vapor d'água, dióxido de carbono, óxido nitroso, metano, óxido de enxofre e funcionam como um "cobertor" diminuindo a quantidade de radiação infra-vermelha reemitida pela Terra para o espaço. Este efeito torna a Terra um planeta habitável para nós, com uma média de temperatura de $15^{\circ} \mathrm{C}$. Se não houvesse essa camada de gases estufa, a superfície terrestre poderia sofrer grandes variações, dificultando a sobrevivência de muitas formas de vida. A tabela 1.3. destaca os gases de efeito estufa e sua contribuição na atmosfera para este fenômeno:

Tabela 1.3. - Contribuição dos gases de efeito estufa na atmosfera.

\begin{tabular}{|c|c|}
\hline GEE & Porcentagem (\%) \\
\hline $\mathrm{CO}_{2}$ & 55 \\
\hline $\mathrm{CFC}$ & 20 \\
\hline $\mathrm{CH}_{4}$ & 15 \\
\hline $\mathrm{N}_{2} \mathrm{O}$ e outros & 10 \\
\hline TOTAL & $\mathbf{1 0 0}$ \\
\hline
\end{tabular}

Fonte: GOLDEMBERG, 1989.

Através da tabela 1.3., fica clara a contribuição do $\mathrm{CO}_{2}$ para o agravamento do efeito estufa. É por este motivo que este gás vem recebendo maiores atenções dentro dos projetos de redução de emissões dos GEE relacionados ao Protocolo.

Guardadas as proporções, o efeito estufa aqui tratado segue o mesmo princípio de uma casa de vegetação, coberta por plástico ou vidro (mais conhecida como estufa), ou mesmo de um automóvel fechado sob o sol. O vidro, nos dois casos, tem a mesma função dos gases de efeito estufa da atmosfera, retendo parte da radiação térmica reemitida pelo interior.

Dos raios do Sol que chegam à Terra, $30 \%$ são refletidos de volta para o espaço, sem que atinjam a superfície. Os $70 \%$ restantes são responsáveis pelo clima e pelas demais condições físicas da Terra. A parte da radiação solar que chega à superfície da Terra é reemitida para o espaço através de ondas longas, 
enquanto as ondas curtas são refletidas pela camada de gases estufa de volta à superfície (GOLDEMBERG, 1989).

O Sol emite raios de onda luz visível, infravermelho, e ultravioleta. De acordo com a United Nations on Environment Programme (UNEP), a superfície da Terra irradia para o espaço uma média de $390 \mathrm{~W} / \mathrm{m}^{2}$ na forma de radiação infravermelha. Destes $390 \mathrm{~W} / \mathrm{m}^{2}, 240 \mathrm{~W} / \mathrm{m}^{2}$ passam pela atmosfera, enquanto que $150 \mathrm{~W} / \mathrm{m}^{2}$ são absorvidos e re-emitidos de volta para a superfície pelos gases de efeito estufa.

Especialistas estudam a possibilidade de o efeito estufa contribuir para a ocorrência mais forte e mais frequente de fenômenos naturais, como o El Niño, devido ao acúmulo dos GEE na atmosfera, provocando um aquecimento do Oceano Pacífico. De acordo com a Environment Protection Agency (EPA, 2000), o El Niño vem ocorrendo no decorrer dos séculos, embora não tenha apresentado a mesma regularidade. Atualmente esse fenômeno tem acontecido com uma frequência de 2 a 7 anos. O El Niño é o forte aquecimento do Oceano Pacífico Equatorial da América do Sul. Seus efeitos são sentidos em todo o mundo e sua ocorrência na década de 1990 pode ter contribuído para a marca recorde de temperatura registrada.

O terceiro relatório do IPCC (2001) afirma que o dióxido de carbono emitido devido à queima de combustíveis fósseis deve ser o gás de efeito estufa dominante nas tendências de aumento de concentração, durante o século XXI. Esta afirmação está apoiada no fato deste gás representar, em quantidade, mais da metade dos GEE existentes na atmosfera.

Por volta de 2100 , as concentrações atmosféricas de $\mathrm{CO}_{2}$ projetadas para o ciclo do carbono devem estar entre 540 e 970 ppm, de acordo com os cenários da SRES (Special Report on Emissions Scenarios ou Documento Especial de Cenários de Emissões). Esta concentração de $\mathrm{CO}_{2}$ prevista indica um aumento de 90 a $250 \%$ acima dos 280 ppm do ano de 1850 . 
A velocidade de emissão destes gases tem preocupado especialistas do meio ambiente. Segundo o IPCC (2001), "a modificação do uso da terra poderia influenciar a concentração de $\mathrm{CO}_{2}$ ". Ainda de acordo com a mesma fonte, "hipoteticamente, se todo o carbono lançado na história pelas mudanças de uso da terra, fosse restaurado à biosfera terrestre no século XX (pelo reflorestamento) a concentração de $\mathrm{CO}_{2}$ seria reduzida entre 40 e 70 ppm."

\subsubsection{Os gases de efeito estufa}

O Protocolo de Quioto (como será visto no item 3.3.) prevê uma redução na emissão dos GEE por parte dos países desenvolvidos. As reduções dos gases dióxido de carbono $\left(\mathrm{CO}_{2}\right)$, metano $\left(\mathrm{CH}_{4}\right)$ e dióxido de nitrogênio $\left(\mathrm{NO}_{2}\right)$ serão calculadas com base no ano de 1990. As reduções dos 3 gases industriais previstos no Protocolo, hidrofluorcarbono (HFC), perfluorcarbono (PFC) e hexafluoreto de enxofre $\left(\mathrm{SF}_{6}\right)$, podem ser calculadas com base no ano de 1990 ou 1995.

De acordo com o IPCC, citado pela Environment Protection Agency ${ }^{10}$ (EPA), há um conceito utilizado, denominado Global Warming Potential (GWP ou Potencial de dano global), que se refere ao poder destrutivo das moléculas de cada gás de efeito estufa. A molécula de $\mathrm{CO}_{2}$ equivale a 1 neste índice de GWP. $\mathrm{O} \mathrm{CH}_{4}$, menos presente na atmosfera, tem um potencial de dano global 21 vezes maior, se relacionado ao dióxido de carbono. O óxido nitroso $\left(\mathrm{N}_{2} \mathrm{O}\right)$ tem um potencial de dano global 310 vezes maior que o do dióxido de carbono. 0 hexafluoreto de enxofre possui um GWP 23.900 maior que o do $\mathrm{CO}_{2}$. Segue-se uma breve descrição dos gases de efeito estufa. 


\subsubsection{Clorofluorcarbonos}

O clorofluorcarbono (CFC) é uma substância artificial criada pelo homem na década de 30 e muito utilizada em refrigeradores e condicionadores. Tem uma molécula de cloro que reage com o $\mathrm{O}_{3}$, destruindo suas moléculas e possibilitando a passagem de UV-B, nocivos ao homem e às plantas. Percebeu-se à partir da década de 60 uma nítida diminuição dessa camada. Essa diminuição, segundo o Instituto Nacional de Pesquisas Espaciais (INPE), é, em média, de 4\% por década.

O Protocolo de Quioto não trata da redução de emissão dos gases CFC, pois estes já estão sob o âmbito do Protocolo de Montreal ${ }^{11}$.

\subsubsection{Hidrofluorcarbono}

O hidrofluorcarbono (HFC) é pouco presente na atmosfera, no entanto possui um GWP considerável, tanto que é um dos 3 gases industriais controlados pelo Protocolo de Quioto. Foi um gás criado pelo homem como alternativa de substituição aos produtos químicos que afetam a camada de ozônio. O HFC é usado para refrigeração, sistemas de ar condicionado, aerossóis, solventes e produção de espuma.

\subsubsection{Perfluorcarbono}

O perfluorcarbono (PFC) é um gás artificial criado pelo homem como alternativa aos produtos químicos prejudiciais à camada de ozônio. É aplicado em refrigeração, solventes, propulsores, espuma e aerossóis. Assim como o

\footnotetext{
${ }^{10}$ Disponível na internet <www.epa.gov/globalwarming/emissions/gwp.html> 06/05/2002.

${ }^{11}$ O Protocolo de Montreal trata de substâncias que destroem a camada de ozônio. Mais detalhes deste Protocolo, no item 3.3.
} 
clorofluorcarbono, é um dos 3 gases industriais controlados pelo Protocolo de Quioto, pelo seu potencial de aquecimento global.

\subsubsection{Hexafluoreto de enxofre}

Utilizado como isolante térmico, condutor de calor e agente refrigerante, o hexafluoreto de enxofre $\left(\mathrm{SF}_{6}\right)$ é um dos gases de efeito estufa controlados pelo Protocolo de Quioto. Embora esteja presente na atmosfera em uma quantidade muito menor em relação ao $\mathrm{CO}_{2}$, acredita-se que o seu potencial de aquecimento global seja 23.900 vezes maior que o do dióxido de carbono (MCT, s.d.).

\subsubsection{Metano}

$\mathrm{O}$ metano $\left(\mathrm{CH}_{4}\right)$ tem uma maior eficiência que $0 \mathrm{CO}_{2}$ como gás efeito estufa. Como é um gás menos abundante na contribuição para o efeito estufa, tem recebido um menor destaque no combate às mudanças climáticas, se comparado ao $\mathrm{CO}_{2}$.

A concentração atmosférica do metano apresentou um acréscimo de 1060 ppb (ou 151\%) desde 1750 e continua a aumentar. Pouco mais da metade das emissões atuais de metano são de responsabilidade do homem: a criação de rebanho bovino e ovino, a cultura do arroz e os aterros sanitários. As emissões de monóxido de carbono ( $\mathrm{CO}$ ) têm sido identificadas recentemente como uma causa no aumento da concentração do gás metano (IPCC, 2001).

\subsubsection{6. Óxido nitroso}

De acordo com o IPCC (2001), o óxido nitroso $\left(\mathrm{NO}_{2}\right)$ é um dos gases estufa de importância; por isso, encontra-se no âmbito do Protocolo de Quioto. 
A concentração de óxido nitroso na atmosfera apresentou um aumento de $46 \mathrm{ppb}$ (ou 17\%) desde 1750 e continua aumentando. Apenas a terça parte do óxido nitroso lançado na atmosfera é de responsabilidade antropogênica, como solos agricultados, alimentação do gado e indústria química.

\subsubsection{Dióxido de carbono}

O dióxido de carbono $\left(\mathrm{CO}_{2}\right)$ é o gás de maior importância dentre os gases de efeito estufa, representando $55 \%$ desses gases na atmosfera (GOLDEMBERG, 1998) e por isto é o GEE que está recebendo maior destaque dentro das discussões a respeito das mudanças climáticas.

Encontra-se na atmosfera, na pequena concentração de $0,035 \%$, mas suficiente para a manutenção de uma temperatura média terrestre de $15^{\circ} \mathrm{C}$, como já foi dito, devido à sua capacidade de absorver os raios infravermelhos.

\subsection{Fotossíntese e Respiração}

\subsubsection{Fotossíntese}

O processo fotossintético não será tratado com profundidade por não ser o foco do presente projeto.

A fotossíntese é o processo pelo qual praticamente toda energia entra na biosfera. $O$ termo fotossíntese significa construção ou síntese pela luz (HALL et al., 1980). A fotossíntese é um processo físico-químico pelo qual se produzem carboidratos a partir de compostos inorgânicos, mediante a transformação de energia solar em química. Pode-se descrever o processo como a absorção de energia luminosa nos clorosplastos (organelas localizadas nas partes verdes de 
uma planta), a degradação (fotólise) da água para obtenção de hidrogênio e oxigênio gasoso e o uso de íons hidrogênio para reduzir o dióxido de carbono até o nível de açúcar.

Há uma forte relação entre seres autótrofos e heterótrofos. Os seres autótrofos, também chamados de fotossintetizantes, são assim classificados, porque conseguem sintetizar seu próprio alimento. Em termos gerais, somos muito dependentes deste processo de forma direta e indireta. Como seres heterótrofos, nos alimentamos de plantas ou de animais que se alimentam de plantas, além de estas proverem oxigênio aos seres vivos através da fotossíntese, e retirarem o dióxido de carbono da atmosfera. O homem ainda faz uso de recursos naturais para fins energéticos, como carvão, gás natural e petróleo. Estes produtos utilizados hoje são provenientes da decomposição de animais e plantas, e sua energia armazenada foi captada há milhões de anos, também pelo processo fotossintético (HALL et al., 1980).

Os organismos fotossintetizantes datam de 3,4 bilhões de anos. O aparecimento desses seres modificou a atmosfera terrestre. Há cerca de 500.000 espécies capazes de realizar fotossíntese. Existe um número de seres heterótrofos de 8 a 10 vezes superior aos seres fotossintetizantes e esses são indispensáveis aos heterótrofos, pois os seres autótrofos constituem sua base alimentícia e provém oxigênio para a sua respiração (WILSON, 1988).

Segundo RAVEN et alii. (1996), a cada ano, mais de 100 bilhões de toneladas métricas de açúcar são produzidas pelos organismos fotossintetizantes em escala mundial. Os organismos fotossintetizantes são aqueles que contêm pigmentos fotossintetizantes (clorofilas, carotenóides e ficobilinas). Esses pigmentos ocorrem em todos os seres eucariontes ${ }^{12}$ fotossintetizantes, cianobactérias e algas verdes.

A equação geral da fotossíntese é a seguinte:

\footnotetext{
${ }^{12}$ São considerados eucariontes aqueles organismos pluricelulares e com reprodução sexuada.
} 


$$
\mathrm{CO}_{2}+\mathrm{H}_{2} \mathrm{O} \longrightarrow \mathrm{CH}_{2} \mathrm{O}+\mathrm{O}_{2}
$$

plantas clorofiladas

Portanto, a água e o dióxido de carbono são transformados em carboidratos para a constituição da planta, além de ser liberado oxigênio do processo. Como pode-se notar, este processo ocorre na presença de luz e em plantas clorofiladas.

\subsubsection{Respiração}

A respiração é um processo que todos os seres vivos realizam. As plantas também respiram, processo esse que se traduz na atividade inversa da fotossíntese. No processo de respiração, o oxigênio é tomado da atmosfera para que os carboidratos (e outros constituintes celulares) sejam convertidos em energia para os processos vitais de manutenção e desenvolvimento que todo ser vivo realiza. Nesta reação são liberados dióxido de carbono, água e energia na forma de calor.

A equação da respiração pode ser representada da seguinte forma:

$$
\mathrm{CH}_{2} \mathrm{O}+\mathrm{O}_{2} \longrightarrow \mathrm{CO}_{2}+\mathrm{H}_{2} \mathrm{O}+\text { energia }
$$

Através da respiração ${ }^{13}$, há uma liberação de dióxido de carbono água e energia para o meio, com o objetivo de obtenção de energia por parte dos seres vivos.

É importante salientar que as plantas, na presença de luz, apesar do processo fotossintético, não deixam de respirar. Sua atividade fotossintética sobrepõe-se à respiratória. Na ausência de luz, a taxa respiratória é maior e a planta não realiza fotossíntese. 
Em condições ideais, segundo HALL et al. (1980), a taxa fotossintética nas partes verdes das plantas é cerca de 30 vezes maior do que a taxa de respiração nos mesmos tecidos. Assim, o processo fotossintético é um fator importante na regulação do oxigênio e dióxido de carbono terrestres.

A fotossíntese e a respiração são processos dependentes entre si e fazem parte de um ciclo biogeoquímico de maior importância: o ciclo do carbono.

\subsection{O ciclo do carbono}

A dinâmica de um ecossistema depende de uma série de fatores e ciclos, como os ciclos biogeoquímicos. Dentre os ciclos biogeoquímicos, estão o da água, do nitrogênio, do fósforo, do carbono, do oxigênio e do enxofre. O ciclo do carbono é um dos ciclos biogeoquímicos de maior importância.

Os organismos vivos são principalmente compostos por água e vários componentes de carbono. O ciclo do carbono é, pois, de maior importância para o sustento da vida em suas mais variadas formas. O carbono é encontrado em maior proporção em rochas, como os carbonatos, geralmente associados com o cálcio em calcários; ou disperso em carbono orgânico e em rochas sedimentárias, particularmente o xisto. Os carbonatos são descritos como contendo carbono inorgânico, com cerca de $3 / 4$ do total de carbono nesta forma e outro 1/4 disperso em componentes orgânicos. O conteúdo de carbono em outros reservatórios (atmosfera, biota do solo, humus do solo, combustíveis fósseis, biota marinha e compostos dissolvidos) representa menos de $1 \%$ do total (O'NEILL, 1994).

A concentração de dióxido de carbono na atmosfera, por exemplo, é de apenas $0,035 \%$ (RAVEN et alii., 1996). Apesar disto, tem um papel fundamental na manutenção da temperatura para o planeta, por absorver radiação

\footnotetext{
${ }^{13} \mathrm{O}$ mesmo processo, na ausência de oxigênio, é denominado fermentação.
} 
infravermelha vinda do Sol. Além do mais, é o gás com a maior responsabilidade pelo agravamento do efeito estufa e que vem recebendo destaque dentre os projetos de redução de emissões de GEE.

Nas plantas, o carbono participa na forma de dióxido de carbono, nos processos de respiração e fotossíntese, além de outras formas na composição dos vegetais. $O$ carbono pode ficar retido na biomassa (tanto na parte aérea, como nas raízes) ou ser liberado para a atmosfera, se este material vegetal for queimado.

\subsection{Florestas}

\subsubsection{Conceituação}

Os conceitos de floresta, florestamento e manejo de florestas são dados a seguir, baseados nos conceitos emitidos nas reuniões da Conferência das Partes. As definições foram retiradas da categoria conhecida como Land Use, Land-Use Change and Forestry (LULUCF - Uso da Terra, Mudança do Uso da Terra e Florestas), que trata dos potenciais Sumidouros, Fontes e Reservatórios relacionados às atividades agropecuárias e florestais, dentro do Protocolo de Quioto. Os conceitos de florestamento, desmatamento, reflorestamento e revegetação serão abordados em seus tópicos respectivos.

Floresta - "É a área mínima de terra de 0,05 - 1 hectare com cobertura de árvore (ou nível equivalente de estoque) de mais de $10-30 \%$ com árvores com o potencial de alcançar uma altura mínima de 2 - 5 metros na maturidade in situ. Uma floresta pode consistir ou em formações florestais fechadas, onde árvores de várias alturas e estágios de crescimento cobrem uma alta proporção do chão, ou em florestas abertas. Novas formações jovens e todas as plantações que ainda estão por alcançar uma densidade de dossel de $10-30 \%$ ou altura das árvores de 2 - 5 metros, estão inclusas em florestas, assim como as áreas que 
normalmente formam parte de áreas florestais que estão temporariamente fora de condição, como resultado de intervenções humanas, como a colheita ou causas naturais, mas que se espera que revertam a florestas."

Florestamento - "É a ação direta do homem na conversão de terras que não tenham sido florestadas por um período de no mínimo 50 anos para terras florestadas por plantação, semeadura e/ou ação humana promovendo semeadura natural."

Manejo de Florestas - "É um sistema de práticas para manejo e uso de terras florestadas no sentido de realizar funções ecológicas (incluindo diversidade biológica), econômicas e sociais da floresta de maneira sustentável".

\subsubsection{Classificação das florestas}

Do ponto de vista silvicultural, as florestas podem ser classificadas quanto à origem, composição, idade ou tipo de essências florestais. Seguem-se as classificações e suas conceituações baseadas em POGGIANI (1989).

A classificação quanto à origem pode distinguir as florestas como naturais ou artificiais. São consideradas artificiais, quando a sucessão é orientada pelo homem e, geralmente, apresenta alguma finalidade econômica (matéria-prima para celulose, papel, chapas, aglomerados, lenha, carvão vegetal, madeira serrada, entre outras). A floresta é natural quando ocorre uma sucessão primária ou secundária natural das espécies vegetais, sem que haja interferência do homem.

Quanto à composição das florestas, estas podem ser classificadas como homogêneas ou heterogêneas (ou ainda puras e mistas, respectivamente). As florestas homogêneas são aquelas formadas somente por uma espécie em toda 
sua extensão. Já as heterogêneas, são formadas por duas ou mais espécies diferentes.

Quanto à idade, as florestas podem ser classificadas como coetâneas, quando todos os exemplares têm a mesma idade ou apresentam uma diferença muito pequena; ou dissentâneas, quando há espécies com idades variadas, como geralmente é o caso de uma floresta natural.

As florestas ainda podem ser classificadas quanto aos tipos de essências. As espécies florestais são reunidas em dois grandes grupos: folhosas e resinosas. As florestas de folhosas, chamadas também de latifoliadas (ou ainda de folhas largas), são aquelas que reúnem as espécies florestais pertencentes às angiospermas dicotiledôneas. Suas folhas podem ser perenes ou caducifólias e produzem tanto madeira mole, como madeira dura. As espécies florestais resinosas, também conhecidas como coníferas, compreendem as gimnospermas (grupo de plantas com as sementes nuas). Essas espécies florestais possuem folhas longas e finas.

\subsubsection{Importância das florestas}

De acordo com a WRI ${ }^{14}$, excluindo-se a Groelândia e a Antártida, cerca de $25 \%$ da superfície terrestre é coberta por florestas. Nos países desenvolvidos a área florestal vem aumentando ligeiramente desde 1980. Nos países em desenvolvimento, no entanto, a área florestal diminuiu quase $10 \%$ neste mesmo período.

As ameaças mais representativas às florestas são a conversão e a fragmentação destas para outras finalidades. A derrubada indiscriminada para a construção de estradas, as aberturas de caminhos para atividades mineradoras e madeireiras e a caça animal estão entre alguns dos fatores de enfraquecimento 
das florestas tanto do seu ponto de vista estrutural, como no ponto vista da biodiversidade lá encontrada.

Os ecossistemas florestais provêm alimentos, madeira para diversas finalidades, além de apresentarem uma série de benefícios ambientais, como o de redução nos riscos de erosão dos solos, a produção de água de boa qualidade para as bacias hidrográficas e o abrigo de aproximadamente $2 / 3$ da biodiversidade terrestre conhecida.

Cerca de 2/3 do território brasileiro são formados por florestas (FAO, 2001). A floresta Amazônica, por exemplo, a maior floresta tropical do mundo, cobre 47\% do território nacional (IBAMA, 2001) e tem cerca de 50 bilhões de $\mathrm{m}^{3}$ de madeira em uma diversidade de aproximadamente 4.000 espécies arbóreas. O Pantanal, a maior planície inundável do mundo e outros biomas, como o Cerrado, a Caatinga e a Mata Atlântica, são outros ecossistemas florestais de importância. As florestas nativas brasileiras chegam a cerca de 550 milhões de hectares.

De maneira geral, o patrimônio florestal brasileiro, pode ser dividido nas seguintes formações :

- Floresta Amazônica (na região Norte);

- Floresta Tropical (regiões Sul e Sudeste);

- Caatinga e Mata do Cocais (Nordeste);

- Cerrados (no Sudeste e Centro-Oeste);

- Campos e matas de araucária (região Sul);

- Mangues (região litorânea);

- Reflorestamentos.

O setor florestal no Brasil apresenta um consumo de madeira de espécies nativas e plantadas que gira em torno de 300 milhões $\mathrm{m}^{3} / a n o$. Gera empregos diretos e indiretos para aproximadamente 2 milhões de pessoas e teve um PIB de

\footnotetext{
${ }^{14}$ World Resources Institute - disponível na internet <www.wri.org> s.d.
} 
21 bilhões de dólares em 1998. Há um incremento médio anual de plantio de 150.000 hectares de formações florestais, o que representa uma demanda crescente desta matéria-prima (SBS, 2000). O Brasil é ainda o maior produtor mundial de madeiras tropicais e $\circ 5^{\circ}$ maior produtor industrial de produtos de madeira. Esses números colocam o país em uma posição vantajosa e de respeito diante do setor florestal mundial e das condições para implantação de novas florestas. Além disso, possui a maior biodiversidade do mundo, com mais de $20 \%$ de todas as espécies do planeta. No sentido de preservação desses biomas e da biodiversidade contida neles, o reflorestamento com espécies plantadas pode ser uma saída para se evitar a pressão exercida sobre as florestas nativas.

\subsubsection{O Código Florestal Brasileiro}

O Código Florestal Brasileiro (lei $n^{\circ} 4771$ ), discutido a seguir, é uma versão que entrou em vigor em 1997. Este código delimita os direitos e deveres atribuídos aos cidadãos que, de alguma forma, se utilizam ou beneficiam-se das terras e florestas existentes no território nacional. É constituído de 50 artigos, dos quais há relevância de se ressaltar e comentar alguns, dada a sua interface com o presente trabalho.

Artigo $12^{\circ}$ - Nas florestas plantadas, não consideradas de preservação permanente, é livre a extração de lenha e demais produtos florestais ou a fabricação de carvão. Nas demais florestas, dependerá de norma estabelecida em ato do Poder Federal ou Estadual, em obediência a prescrições ditadas pela técnica e às peculiaridades locais.

Comentário - Este artigo estabelece a livre atividade e o emprego de florestas plantadas para quaisquer finalidades. De certa forma, é um estímulo ao desenvolvimento de tal modalidade florestal, em contrapartida às florestas naturais, que podem ser exploradas mediante somente a prescrição ou autorização de um órgão superior. 
Artigo $21^{\circ}$ - As empresas siderúrgicas, de transporte e outras, à base de carvão vegetal, lenha ou outra matéria-prima vegetal, são obrigadas a manter florestas próprias para a exploração racional ou a formar, diretamente ou por intermédio de empreendimentos dos quais participem, florestas destinadas ao seu suprimento.

Comentário - O artigo 21 determina que todas as empresas que tenham como base a matéria-prima vegetal devem, obrigatoriamente, estabelecer suas áreas com cultura das mesmas. Uma expansão no setor industrial que se utiliza de madeira demanda um aumento na área de florestas plantadas, podendo até aderir a projetos paralelos de reflorestamento como forma de diminuir os gastos de implantação e obter a matéria-prima com uma maior velocidade.

Artigo $26^{\circ}$ - Constituem contravenções penais, puníveis com três a um ano de prisão simples ou multa de uma a cem vezes o salário mínimo mensal do lugar e da data da infração ou ambas as penas cumulativamente:

h) receber madeira, lenha, e outros produtos procedentes de florestas, sem exigir a exibição de licença do vendedor, outorgada pela autoridade competente, e sem munir-se da via que deverá acompanhar o produto, até o final do beneficiamento;

Comentário - Este artigo tange em um aspecto importante que é a fiscalização da matéria-prima utilizada por muitas empresas do setor madeireiro. Significa que a receptação, a venda ou a circulação de madeira que não leva consigo a discriminação da procedência ou autorização para tal constitui uma contravenção. O emprego de florestas plantadas para a utilização da madeira nestes setores é uma via descomplicada e de mais fácil aferição quanto à procedência.

Artigo $46^{\circ}$ - No caso de florestas plantadas, o Instituto Brasileiro do Meio Ambiente e dos Recursos Naturais Renováveis (IBAMA) zelará para que seja preservada, em cada município, área destinada à produção de alimentos básicos e pastagens, visando ao abastecimento local. 
Comentário - No presente estudo, a idéia proposta de emprego da atividade de reflorestamento se dá justamente em áreas não conflitantes com as áreas já estabelecidas para pecuária, agricultura ou florestas.

\subsubsection{Programa Nacional de Florestas}

O Programa Nacional de Florestas (PNF), decreto $n^{\circ} 3.420$, foi criado em 20 de abril de 2000. Sua criação foi uma iniciativa do governo federal e tem o objetivo manifesto de estimular o reflorestamento no Brasil. Dentre suas metas, está o incremento da área de reflorestamento de 170.000 hectares para 630.000 hectares anuais, a partir de 2004. Essa iniciativa tem o objetivo não só de diminuir os números do desmatamento ilegal, como o de evitar que o Brasil torne-se importador de madeira dentro de 4 anos.

Um exemplo deste problema para o estado de São Paulo: em 1991/92, a área plantada com eucalipto no estado era de 610.544 ha, tendo sido reduzida para 608.128 ha, em 1998/99. No caso de Pinus, essa queda foi mais acentuada. A explicação para esta diminuição da área plantada aponta parao desenvolvimento de indústrias de base florestal, que vieram demandando um volume maior desta matéria-prima. De acordo com Francisco Kronka, do Instituto Florestal, "o abastecimento industrial tem sido assegurado pelo aumento da produtividade" (RABELLO, 2002).

De acordo com a REVISTA DA MADEIRA (2001), há uma unanimidade entre os setores industriais de base florestal no reconhecimento de que 0 incremento médio anual deveria exceder os 400.000 hectares. No entanto, nem 1/3 desta demanda está sendo atendida. Acredita-se que o déficit seja considerável para as atividades de serraria e laminação e que essa crise se inicie já em 2003.

Mais especificamente, o PNF tem como objetivos: 
- Estimular o uso sustentável de florestas nativas e plantadas;

- Fomentar as atividades de reflorestamento, notadamente em pequenas propriedades rurais;

- Apoiar as iniciativas econômicas e sociais das populações que vivem em florestas;

- Reprimir desmatamentos ilegais e a extração predatória de produtos e sub-produtos florestais, conter queimadas acidentais e prevenir incêndios florestais;

- Promover o uso sustentável das florestas de produção, sejam nacionais, estaduais, distritais ou municipais;

- Ampliar os mercados interno e externo de produtos florestais;

- Valorizar os aspectos ambientais, sociais e econômicos dos serviços e dos benefícios proporcionados pelas florestas públicas e privadas;

- Estimular a proteção da biodiversidade e dos ecossistemas florestais.

Pode-se observar, de acordo com os objetivos do PNF, que existe uma pronta demanda de madeira serrada além da disposição na implementação e fomentação de projetos florestais em pequenas propriedades rurais. O presente projeto apresenta uma forte interface com o PNF e podem ser estabelecidos vínculos para aquisição de subsídios e o desenvolvimento do projeto.

\subsection{As florestas plantadas no Brasil}

O Brasil possui uma vocação florestal, tanto para a existência e formação de florestas naturais, como para a formação de novos maciços florestais de espécies exóticas com diversas finalidades.

O presente trabalho concentra-se nas florestas monocultivadas de eucalipto, por serem, dentre as florestas plantadas, as mais representativas no Brasil e no mundo. 
As florestas plantadas no Brasil podem ser consideradas irrelevantes, frente à imensidão das florestas nativas existentes. Representam aproximadamente $1 \%$ da cobertura florestal, com cerca de 5 milhões de hectares espalhados, em sua maior parte, por 10 estados. Dentre estes estados, o destaque fica por conta de Minas Gerais e São Paulo, que juntos representam mais de $70 \%$ de todo eucalipto plantado em território nacional (REVISTA DA MADEIRA, 2001). No entanto, estas florestas plantadas têm um papel fundamental para o setor florestal brasileiro e, consequentemente, para a economia nacional, servindo de matéria-prima para o setores de celulose e papel, chapas, aglomerados, laminados e serraria, dentre outros.

As florestas plantadas no Brasil são predominantemente formadas pelos gêneros Pinus e Eucalyptus, correspondendo a aproximadamente 1,8 e 3 milhões de hectares, respectivamente. Tais gêneros foram aqui introduzidos e encontraram um ambiente bastante favorável para o seu desenvolvimento. As condições de ambiente favorávele o emprego de modrnas técnicas florestais de manejo fizeram com que o eucalipto alcaçasse no Brasil os maiores índices de produtividade do mundo.

Outras espécies, como a Araucária, e a Acácia são também empregadas no setor florestal brasileiro, porém em uma escala menor, com 80.000 ha e 60.000 ha plantados, respectivamente (FBDS, 1994).

\subsection{Desmatamento}

De acordo com os documentos divulgados pela COP, a definição de desmatamento, que pelo texto da Convenção é chamada de desflorestamento, é a seguinte: 
Desflorestamento - "É a ação direta do homem na conversão de terras florestadas em terras não florestadas."

O desmatamento ocorre por razões naturais e razões antrópicas (causadas por ação humana). Dentre as razões antrópicas de desmatamento, pode-se citar:

- Abertura de áreas para a pecuária;

- Extração de lenha para uso doméstico;

- Implementação de atividades agrícolas de subsistência;

- Abertura de estradas, ferrovias e linhas de transmissão de energia elétrica;

- Crescimento urbano e industrial;

- Atividades das madeireiras, sobretudo daquelas que operam ilegalmente;

- Inundação de grandes áreas para o estabelecimento de usinas hidrelétricas;

- Chuva ácida.

Alguns fenômenos de origem natural também contribuem para 0 desmatamento:

- Chuvas (falta ou excesso);

- Ventos (ciclones, tornados, furacões);

- Descargas elétricas (provocando incêndios);

- Tremores de terra;

- Erupções vulcânicas.

Se comparadas as razões naturais de desmatamento e as antrópicas, verifica-se que estas últimas sãoas mais danosas para o meio ambiente.

Segundo a World Resources Institute (WRI, s.d.), se o ritmo atual de desmatamento continuar é possível que a quantidade total de espécies que habitam as florestas diminuam entre 4 e $8 \%$. 
A mata remanescente na Mata Atlântica é de apenas 4\%. A floresta Amazônica teve no ano de 2000, cerca de 1.700 .000 hectares desmatados. Tal índice equivale a $0,5 \%$ ao ano. Cerca de $14 \%$ de toda a floresta amazônica já foi destruída.

O desmatamento é uma atividade que emite dióxido de carbono por conta da remoção e queima da biomassa: no caso da floresta Amazônica, são 140 milhões de toneladas anuais. Se este número fosse somado aos 70 milhões de toneladas emitidos por outras fontes, o Brasil pularia no ranking de vigésimo à sexto colocado em emissões de gases de efeito estufa (GOLDEMBERG, 2001).

Em florestas naturais, ocorre um problema de mau aproveitamento de espécies. Uma floresta tropical pode abranger um grande número de espécies arbóreas em apenas 1 hectare. $O$ aproveitamento destas espécies dentro de uma floresta é pequeno, se estas forem utilizadas para fins. Pode-se dar como exemplo a floresta Amazônica. Esta formação florestal possui em média 200 espécies diferentes por hectare. Dessas 200, apenas 20 espécies são de interesse comercial; e dessas 20 espécies, apenas 5 têm importância para exportação (WATAl, 1991).

Segundo LORENZI (2000b.), o governo do estado de São Paulo anunciou haver 38 espécies de árvores extintas, além de 29 criticamente em perigo e outras 118 espécies em perigo de extinção.

As forças de mercado, o tráfico ilegal de madeiras, a falta de cumprimento da legislação e a ineficiência da vigilância florestal nas florestas brasileiras são fatores que reforçam a continuação dos desmatamentos. Se houver uma política adequada de uso dos recursos naturais, um manejo florestal inteligente que projete a demanda de matéria-prima vegetal para fins industriais e uma política ambiental, no sentido da diminuição da pressão sobre as florestas nativas, pode haver uma lenta reversão da situação atual em relação às taxas de 
desmatamento. O reflorestamento com espécies de rápido crescimento pode ajudar na reversão desta situação.

\subsection{Reflorestamento}

O conceito de reflorestamento dado a seguir também foi retirado dos textos da COP relacionados às discussões sobre as mudanças climáticas.

Reflorestamento - "É a conversão por indução direta do homem de terras não florestadas para terras florestadas através de plantio, semeadura e/ou na promoção induzida pelo homem de semeadura natural, ou terras que eram florestadas mas que tinham sido convertidas em terras não florestadas. Para o primeiro período de compromisso ${ }^{15}$, as atividades de reflorestamento estarão limitadas àquelas ocorridas em terras que não continham florestas em 31 de dezembro de 1989."

Revegetação - "É a atividade de ação direta do homem para incrementar estoques de carbono em áreas através do estabelecimento de vegetação que cubra uma área de no mínimo 0,05 hectares e que não confronte com as definições de florestamento e reflorestamento contidas aqui."

A atividade de reflorestamento pode trazer uma série de benefícios como:

- O aumento de empregos diretos e indiretos;

- A diminuição da pressão sobre as florestas nativas;

- A proteção da superfície do solo (diminuindo-se os riscos de erosão);

- A proteção de bacias hidrográficas em que a atividade se localiza;

- Maior biodiversidade;

- Retenção de dióxido de carbono;

- Produção de oxigênio. 
Como já é sabido, a composição de espécies dentro de um processo de reflorestamento pode ser tanto homogênea, como heterogênea (mista). A floresta da Tijuca (no Rio de Janeiro) recebeu o primeiro reflorestamento heterogêneo no Brasil. Ocorreu em 1862 e teve a finalidade de proteção dos mananciais que abasteciam a cidade. A área beneficiada foi de 3.200 hectares e em 13 anos foram plantadas mais de 100.000 árvores de espécies nativas (LEÃO, 2000). Os primeiros reflorestamentos homogêneos no Brasil (como será visto no ítem 2.1.) ocorreram no início do século $\mathrm{XX}$, com o objetivo de se atender à demanda de madeira para a produção de dormentes, lenha e carvão.

No presente estudo, será considerado para exercício e discussão um reflorestamento homogêneo: cada talhão cultivado será composto por apenas uma espécie de eucalipto.

\subsubsection{Projetos de reflorestamento no Brasil}

O reflorestamento já ocorre no Brasil em diversas escalas e com diversas finalidades. Empresas de muitos setores, organizações e até o meio acadêmico têm se interessado por essa atividade, visando reparos ambientais, atendimento na demanda de matéria-prima para indústrias dos mais variados setores, melhoria na qualidade de produção e até a participação em um futuro mercado mundial emergente de carbono.

Os projetos citados a seguir têm, predominantemente, o objetivo de participação no MDL, através da comercialização de créditos de carbono.

\footnotetext{
${ }^{15}$ O primeiro período de compromisso corresponde de 2000 a 2012.
} 
A multinacional francesa Peugeot pretende reflorestar uma área de 12.000 hectares no Mato-Grosso, em terras degradadas, antes destinadas à atividade pecuária ${ }^{16}$.

A empresa Texaco, em parceria com sociedades ambientalistas - a Sociedade de Pesquisa em Vida Silvestre e Educação Ambiental (SPVS) e a The Nature Conservancy (TNC) - está enriquecendo cerca de 1.000 hectares de mata, no entorno da Reserva Morro da Mina, no município de Antonina, no Paraná.

Ainda no Paraná, são exemplos de reflorestamento, um projeto da American Electric Power de 7.000 hectares, desde 1999 e da General Motors, de 12.000 hectares, dentro da APA de Guaraqueçaba ${ }^{17}$.

A Companhia Vale do Rio Doce possui uma área de 387 hectares na região da Amazônia, onde foram investidos US\$12 milhões com o plantio de eucalipto. A CVRD possui ainda uma área de 73.000 hectares, onde estuda a implantação de um novo projeto, visando o sequestro de carbono. A Petrobrás pretende investir até 2003 , US $\$ 1,3$ bilhões em 3.000 novos projetos, alguns deles destinados ao reflorestamento ${ }^{18}$.

A empresa Plantar, em uma associação com o Fundo Protótipo de Carbono (Prototype Carbon Fund - PCF) do Banco Mundial, fechou um acordo para produzir ferro-gusa com carvão vegetal proveniente de florestas plantadas de eucalipto em substituição ao carvão mineral. O grupo vai investir US\$23 milhões para plantar 23.000 hectares e pretende aprisionar 3 milhões de toneladas de carbono em $21 \operatorname{anos}^{19}$. Vale ressaltar que o Projeto Plantar foi o único, até o momento, a ter seus créditos de carbono comercializados. A atividade de

16 GARCIA, R. Poço de carbono: Peugeot afasta práticas agressivas ao meio ambiente. Folha do Meio Ambiente. Brasília ano 11. n.106 jul. 2001.

17 JOHN, L. Texaco terá projeto de sequestro de carbono no Brasil. O Estado de São Paulo, 03/09/2001.

${ }^{18}$ GAZETA MERCANTIL Petrobrás e Vale têm projetos ambientais. (disponível na internet $<$ www.forumclima.org.br> 12/11/2001a.).

${ }_{19}$ Disponível na internet <www.plantar.com.br> s.d. 
reflorestamento é usada como meio do processo. Por esse motivo, A Plantar desenvolve uma atividade voltada para o MDL de substituição energética, e não de reflorestamento.

O Projeto de Sequestro de Carbono da llha do Bananal e de seu Entorno (PSCIB) está previsto para um período de duração de 25 anos. A ilha do Bananal é a maior ilha fluvial do mundo, com 2 milhões de hectares de área. No projeto, pretende-se preservar 200.000 hectares de florestas existentes no Parque Nacional do Araguaia (PNA) e no Parque Estadual do Cantão (PEC), além de reflorestar mais 60.000 hectares no PNA e nos cinco municípios que se encontram dentro da área delimitada para o projeto. Com isso, calcula-se que nos 25 anos do projeto sejam sequestrados 25.110 .000 toneladas de carbono (tanto em florestas alagáveis como em florestas de terra firme). $O$ projeto pretende mobilizar a população local para participação (REZENDE et alii., 2001).

A Central \& South West Corporation (CSW), a segunda maior concessionária de energia elétrica dos EUA, prevê para um prazo de 40 anos a recuperação, proteção e manejo de aproximadamente 7.000 hectares de Mata Atlântica no Paraná.

Pode-se ainda citar o projeto Florestar ${ }^{20}$, que tem como meta o plantio de 4 milhões de árvores nos próximos 25 anos, dentro do estado de São Paulo. Este projeto não tem o objetivo de participação no MDL e sim, de reposição florestal em uma área do estado.

O Projeto Floram ${ }^{21}$, de 1990, propõe uma área de 20 milhões de hectares (o que corresponde a $2,3 \%$ do território brasileiro) a serem reflorestados em um prazo de 20 a 30 anos (IEA, 1990). Este projeto, quando elaborado, não visava um possível ingresso na comercialização de créditos de carbono, até porque a

\footnotetext{
${ }^{20}$ Disponível na internet $<w w w$.floresta.org.br $>$ s.d.

21 Tal projeto, apesar do grande potencial para desenvolvimento, não saiu do papel. O Projeto Floram (Flor=florestas, Am=ambiente), mesmo não tendo sido implantado, serve de base para
} 
Convenção sobre Mudança do Clima ainda não havia ocorrido. Apesar disto já reconhecia o problema do efeito estufa e tinha como um dos objetivos a retenção do excesso de dióxido de carbono atmosférico. O objetivo maior do projeto é a reposição florestal de uma área significativa do Brasil e a conquista de seus benefícios sócio-ambientais (empregos, melhoria da biodiversidade e diminuição da pressão sobre as florestas naturais, entre outros).

estudiosos e preconiza no Brasil os projetos de mega-reflorestamento, tendo o sequestro de carbono como um de seus objetivos finais. 


\section{Capítulo II}

O segundo capítulo trata do gênero Eucalyptus, suas características gerais, sua importância diante do setor florestal mundial e brasileiro, seu potencial como exemplar de substituição às espécies nativas, os impactos e os benefícios ambientais trazidos pelo seu cultivo. Serão enumerados os usos que o gênero proporciona e será feita uma breve discussão sobre a madeira serrada, uma das finalidades para o cultivo de eucalipto.

As tecnologias, características específicas e métodos de cultivo do gênero Eucalyptus serão abordados com pouca profundidade, pois o trabalho foca a aplicação da cultura do eucalipto dentro dos moldes de um mecanismo de flexibilização imposto por um tratado mundial sobre o clima. 


\section{O eucalipto}

\subsection{Histórico}

Historiadores mencionam a introdução do eucalipto na Europa por volta de 1774, para fins ornamentais. Seus primeiros ensaios para produção em escala comercial foram em 1854. Na Índia, os primeiro plantios deram-se em 1843 e na África do Sul, em 1828. É provável que o Chile tenha sido o primeiro país da América do Sul a introduzir o gênero, em 1823 (REVISTA DA MADEIRA, 2001).

No Brasil, o gênero Eucalyptus foi introduzido em 1825 como espécie ornamental e como quebra-vento. Para finalidades econômicas seu uso iniciou-se em 1903, quando eram necessários dormentes para atender ao desenvolvimento das estradas de ferro através da Companhia Paulista de Estradas de Ferro CPEF (ANDRADE, 1961).

Sua introdução em escala comercial teve ainda a finalidade de produção de lenha e carvão. Logo começou a ser utilizado para estruturas simples, como é o caso de postes para iluminação, mourões para cerca e como matéria-prima para papel, celulose, chapas de fibra, aglomerados e móveis.

Navarro de Andrade, considerado pai da eucaliptocultura no Brasil, desenvolveu experiências de 1904 a 1909 no Horto Florestal de Jundiaí, comparando várias espécies nativas - Peroba, Cabreúva, Jequitibá, JacarandáPaulista e Pinheiro-do-Paraná - com o eucalipto, tendo esse se destacado das demais espécies supracitadas quanto à produtividade e outras vantagens que serão descritas a seguir.

De sua introdução até o momento em que passou a ser cultivado em escala comercial, estima-se que o Brasil tenha chegado aos 400.000 hectares em área de eucalipto plantado. Em 1966, com o estabelecimento dos incentivos fiscais para o reflorestamento (que duraram 24 anos), a fim de atender à demanda de 
matéria-prima utilizada para as regiões sul e sudeste, houve um salto na produção de eucalipto. De acordo com a FAO (1981), citada por LIMA (1987), em 1973 o Brasil já era o maior produtor mundial em extensão de áreas plantadas com eucalipto: aproximadamente 1.052.000 hectares. Na mesma época, as plantações mundiais de eucalipto chegavam a 4 milhões de hectares.

\subsection{Características gerais do eucalipto}

\subsubsection{Origem}

O eucalipto é uma espécie que tem origem na Austrália, com exceção de duas espécies (E. urophylla ${ }^{22}$ e E. deglupta). O Serviço Florestal da Austrália já identificou 670 espécies do gênero Eucalyptus (REVISTA DA MADEIRA, 2001).

\subsubsection{Descrição}

O eucalipto pertence à família das mirtáceas, a mesma da goiabeira, jabuticabeira e pitangueira, entre outras. As espécies pertencentes à esta família são plantas lenhosas, arbustivas ou arbóreas, com folhas inteiras de disposições alternas ou opostas e às vezes cruzadas com estípulas muito pequenas.

De acordo com PRYOR (1976), citado por LIMA (1987), a maioria das espécies de eucalipto conhecidas são árvores típicas de florestas altas atingindo alturas que variam entre 30 e 50 metros; e florestas abertas com árvores menores atingindo de 10 a 25 metros. Cerca de 30 ou 40 espécies são arbustivas, conhecidas como "Mallees", caraterizadas por apresentarem diversos troncos oriundos de um único núcleo lenhoso subterrâneo. Algumas espécies atingem

\footnotetext{
${ }^{22}$ Espécie dentre as mais cultivadas no Brasil, a E. urophylla é nativa de algumas ilhas orientais do arquipélago de Sonda que compreende as ilhas Timor, Flores, Adonara, Lomblem, Pantar, Alor e Wetar, situadas ao norte da Austrália.
} 
alturas superiores a 70 metros, como o E. grandis e o E. deglupta. A espécie pode atingir, excepcionalmente, 100 metros de altura, sendo considerada a espécie florestal latifoliada mais alta do mundo.

A madeira de eucalipto é usada para muitas finalidades, onde o manejo e o tempo de cultivo são variáveis e dependentes do produto final. Portanto, no caso do eucalipto, o produto final é o fator determinante do ciclo da cultura. A cultura é submetida a um ciclo curto, quando a finalidade da madeira se dá para celulose, papel, carvão, lenha, paletes e caixotaria, tendo-se a colheita, entre 7 e 10 anos após o plantio. Neste caso, a área é reaproveitada, permitindo-se mais dois ciclos seguintes, ou seja, mais duas rebrotas até se que faça a reforma da área. O ciclo longo é aquele que destina o produto final à movelaria, construção civil e outros fins que exijam a madeira com um diâmetro maior. Neste ciclo, a madeira pode ser colhida a partir dos 14 anos até os 25 anos, tendo-se uma variação no tempo de cultivo atrelada à finalidade do produto, ao sistema de cultivo, espaçamento e adubação, entre outros fatores.

O gênero, devido à sua diversidade de espécies, possui uma alta gama de adaptação edafoclimática ${ }^{23}$, podendo ser encontradas espécies que se adaptem bem em climas que vão de $18^{\circ} \mathrm{C}$ negativos até $35^{\circ} \mathrm{C}$ positivos, e em solos que apresentam uma variação desde arenosos até solos encharcados (REVISTA DA MADEIRA, 2001).

\subsubsection{Classificação do gênero Eucalyptus dentro do Reino Vegetal}

Faz-se necessária a classificação do gênero Eucalyptus dentro do Reino Vegetal para uma melhor situação e caracterização das espécies estudadas: 


\section{O Reino Vegetal}

I Farenógamas - plantas com flores

1) Angiospermas - plantas que produzem frutos

a) Monocotiledôneas

b) Dicotiledôneas

2) Gimnospermas - plantas sem frutos

II Criptógamas - plantas que não produzem flores.

1) Pteridófitas

2) Musgos

3) Hepáticas

4) Algas*

5) Fungos*

*Os líquens, associação de algas e fungos, são formações de um processo denominado simbiose (junção de algas cianofíceas ou clorofíceas e fungos - Ascomicetos e Basidiomicetos).

O gênero Eucalyptus, tratado no presente trabalho, é classificado como um vegetal do grupo das Farenógamas, divisão das angiospermas, classe das dicotiledôneas e família das mirtáceas.

\subsubsection{Especificações técnicas}

Para o presente trabalho não será feita a descrição das atividades, pertencentes às etapas de implantação, manutenção e colheita, pois o foco deste estudo está na discussão da viabilidade de um projeto florestal sob a ótica do Protocolo de Quioto. Apesar do não aprofundamento dos aspectos técnicos da cultura, serão discutidos alguns pontos considerados de importância.

\footnotetext{
${ }^{23}$ Adaptação de clima e solo.
} 


\subsubsection{Cultivo do eucalipto}

O cultivo do eucalipto pode ser dividido em duas etapas: implantação e manutenção. A implantação consiste na escolha da área, preparo do solo (com aração e descompactação, se for o caso), abertura das covas, adubação, escolha da variedade mais adequada, plantio e irrigação. A manutenção é a etapa que sucede a implantação, onde o objetivo é o acompanhamento da cultura, para que essa tenha seus melhores rendimentos possíveis. Conhecida também como a etapa dos tratos culturais, a manutenção consiste em uma série de atividades, como a irrigação, capina manual ou mecânica, desbaste, desgalhamento, controle de pragas, controle de doenças e adubação.

No final do ciclo da cultura é realizada a colheita, que pode ser manual ou mecanizada, variando com a dimensão da área onde a cultura está instalada, a inclinação do terreno, o poder de aquisição do proprietário, entre outros fatores.

\subsubsection{Alelopatia}

Segundo FISCHER (1980), citado por LIMA (1987), algumas espécies de eucalipto possuem substâncias alelopáticas (fenólicos e terpenos), afetando outras espécies de gramíneas e herbáceas. Estas substâncias inibidoras podem ser liberadas por volatilização, lixiviação e exudação, assim como pela decomposição da matéria orgânica. Geralmente, o resultado da ação inbidora é o retardo no crescimento de outras espécies. O fenômeno da alelopatia ocorre em outras espécies vegetais e é dependente da interação com outros fatores do meio. Vários autores (LERNER \& EVENARI, 1961; MACLAREN, 1983; RUDRAPA, 1984; RAO \& REDDY, 1984), citados por LIMA (1987), destacam que as referências encontradas de espécies de eucalipto que possuem substâncias alelopáticas são as seguintes: E. camaldulensis, E. globulus, E. rostrata, E. piluraris, E. microteca e E. hybrid. A USP possui uma área florestada com espécies de eucalipto no km 221 da rodovia Castello Branco, na região de Itatinga, 
interior do estado de São Paulo. Esta área, além dos antigos eucaliptos, possui um sub-bosque bastante desenvolvido e composto por outras espécies (que não o eucalipto), o que comprova a possibilidade de uma regeneração natural das espécies daquela região, além de o efeito alelopático estar restrito somente à algumas espécies, e não ao gênero. Culturas como aveia, trigo, fumo, cevada e centeio também apresentam o efeito alelopático (ALTIERI et al., 1983; JOBIDON et al., 1989a.; JOBIDON et al., 1989b., citados por LIMA, 1996).

\subsubsection{Consumo de água}

O reflorestamento com espécies de eucalipto não aumenta as chuvas, mas também não conduz à desertificação. Sua atuação sobre o solo é benéfica, diminuindo o processo de erosão, melhorando as condições de infiltramento e armazenagem de água no solo, assim como as propriedades químicas, físicas e sua feritilidade. A interceptação por chuvas de uma floresta plantada de eucalipto é cerca de $7 \%$ menor que as florestas naturais de eucalipto e de 12 a $15 \%$ menor que as florestas tropicais (LIMA, 1996).

\subsubsection{Biodiversidade}

Uma monocultura, quer seja de eucalipto, quer seja de qualquer outro vegetal, é notadamente acolhedora de um número reduzido quanto à biodiversidade (LIMA, 1987; POGGIANI, 1989; LIMA, 1996). Ou seja, a implantação de uma floresta homogênea reduz de forma drástica o número de espécies do local. Mas com o tempo, aquelas espécies que se adaptam a esse novo habitat conseguem aumentar sua população em grande número (POGGIANNI, 1989). 


\subsubsection{Pragas e doenças}

FILHO et al. (1986) define o manejo de pragas e doenças como "a manutenção de agentes destruidores a níveis toleráveis, pelo uso planejado de uma variedade de técnicas preventivas, supressoras ou reguladoras, e estratégias que sejam biológica e ecologicamente eficientes".

Dentre as pragas do Eucalyptus, os maiores danos são causados pelos desfolhadores das ordens hymenoptera (formigas cortadeiras), lepidóptera (lagartas), coleóptera (besouros de folhas) e isóptera (cupins). Porém, as maiores pragas do eucalipto, são as formigas cortadeiras dos gêneros Atta spp. e Acromyrmex spp., conhecidas como saúva e quenquém, respectivamente.

Para as formigas cortadeiras, o controle se dá geralmente através de iscas tóxicas na forma de granulados. Para as demais pragas, pode-se recorrer à forma química (através do uso de inseticidas), física (controle através do fogo), biológica (uso de feromônios) ou ao emprego de inimigos naturais.

As doenças não são um fator de grande importância para a cultura do eucalipto. Pode-se citar, no entanto, as doenças de maior ocorrência listadas em comum por FERREIRA (1986) e FILHO (1986), como a ferrugem (Puccinia psidii), o cancro (Cryphonectria cubensis), e as manchas foliares, causadas por Cylindrocladium spp. Para a ferrugem, o controle se dá evitando-se o plantio de espécies de procedências suscetíveis. Para o controle do cancro, aconselha-se não plantar as espécies em regiões de risco da doença ou que se proceda com o plantio de espécies resistentes. Para o controle de manchas foliares, recomendase o emprego de mudas resistentes (FERREIRA, 1986). 


\subsection{Descrição das espécies utilizadas}

Segue-se a descrição e caracterização das três espécies selecionadas para implementação no projeto. As espécies Eucalyptus grandis, Eucalyptus saligna e Eucalyptus urophylla representam 55, 17 e 9\% respectivamente, de todo o eucalipto plantado em escala comercial no país. Significa que estas três espécies são responsáveis por $81 \%$ do gênero cultivado no Brasil (REVISTA DA MADEIRA, 2001). No desenvolvimento da metodologia (capítulo V), será discutido o motivo da escolha destas três espécies em especial.

As características descritas das três espécies que se seguem foram retiradas da REVISTA DA MADEIRA (2001) e do Projeto Chave de Identificação de Espécies Florestais (IPEF, s.d.).

\subsubsection{Eucalyptus grandis Hill ex-Maiden}

\section{Habitat}

Com ocorrência natural na Austrália, esta espécie aparece em três populações distintas: ao norte do estado de New South Wales e em direção ao norte, ao redor de Bandaberg (entre as latitudes 25 e $33^{\circ} \mathrm{S}$ ); pequenos povoamentos a oeste de Mackay, na parte central de Queensland (latitude $21^{\circ} \mathrm{S}$ ); ao nordeste de Townsville, para o oeste de Bloomfield e ao norte de Queensland (latitude 16 a $19^{\circ} \mathrm{S}$ ). Esta espécie encontra-se em áreas com altitudes que vão desde o nível do mar até 600 metros e de 500 a 1.100 metros de altitude nas áreas mais ao norte, com precipitações entre 1.000 e $3.500 \mathrm{~mm}$ anuais e temperatura máxima média variando de 24 a $30^{\circ} \mathrm{C}$ e a mínima média variando de 3 a $8^{\circ} \mathrm{C}$. 


\section{Características da espécie}

A árvore adulta é alta, atingindo de 45 a 55 metros de altura e grossa, com um diâmetro à altura do peito (DAP) de 1,2 a 2 metros. Pode, excepcionalmente, atingir 75 metros de altura e um DAP de 3 metros. Possui geralmente o fuste liso nos $2 / 3$ a $3 / 4$ superiores do tronco.

A madeira é considerada medianamente leve e fácil de ser trabalhada. É considerada ainda de baixa estabilidade, mas elevada permeabilidade. É utilizada na Austrália, África do Sul, Brasil e Argentina com finalidade para construções civis ou serraria, quando empregado o ciclo longo de sua cultura. Quando a cultura é submetida a um ciclo curto, pode-se utilizar a madeira para caixotes, mourões, carvão e paletes. A madeira proveniente de ciclos curtos apresenta problemas de empenamento, contrações e rachaduras, quando do desdobro. A madeira desta espécie convenientemente manejada pode produzir madeira de boa qualidade para serraria. É a principal espécie utilizada para produção de celulose, painéis, aglomerados e chapas duras; é mais resistente que o $E$. saligna e menos resistente que o E. urophylla.

\section{Adaptação no Brasil}

Esta espécie é a mais cultivada no Brasil. É uma sensível a geadas severas e relativamente resistente à deficiência hídrica. Apresenta alta incidência de bifurcações e seca de ponteiros em solos pobres ou que tenham deficiência de boro. A madeira é considerada moderadamente leve, com cerne diferenciado e possui um crescimento e rendimento volumétrico superiores em relação às outras espécies de eucalipto. 


\subsubsection{Eucalyptus saligna Sm}

\section{Habitat}

Também de ocorrência natural da Austrália, na região sul de Queensland e na região litorânea e vales das cadeias montanhosas próximas ao litoral de New South Wales, nas latitudes entre 28 e $35^{\circ} \mathrm{S}$, com altitudes variando desde o nível do mar até 1.000 metros. Há uma precipitação média no local de 800 a 1.200 mm com chuvas distribuídas durante o ano todo. O período seco não ultrapassa 4 meses. A temperatura média máxima varia entre 28 e $30^{\circ} \mathrm{C}$ e a média mínima entre 3 e $4^{\circ} \mathrm{C}$. Podem ocorrer geadas de 5 a 10 dias por ano.

\section{Características da espécie}

Esta espécie, em sua fase adulta, pode atingir de 30 a 55 metros de altura e 2 metros de DAP. Excepcionalmente, sua altura pode chegar a 65 metros e seu DAP a 2,5 metros. Seu fuste é considerado de excelente forma.

A madeira desta espécie tem semelhança com a madeira da E. grandis. É considerada leve e fácil de ser trabalhada em operações de usinagem. É considerada de baixa estabilidade, mas de elevada permeabilidade. Por sua versatilidade pode ser utilizada tanto como madeira para construções civis e movelaria, como para paletes, mourões, celulose, papel, painéis, aglomerados e carvão.

A madeira proveniente de ciclos curtos apresenta problemas de empenamento, contrações e rachaduras, nos processos de desdobro e secagem. As árvores, se convenientemente manejadas, podem produzir madeira de boa qualidade para laminação. 


\section{Adaptação no Brasil}

No Brasil, é a segunda espécie em área plantada (depois do E. grandis); apresenta tolerância ao fogo baixo e alta capacidade de regeneração por brotação.

\subsubsection{Eucalyptus urophylla S. T. Blake}

\section{Habitat}

Essa é uma das duas espécies de ocorrência natural fora da Austrália. Endêmica da ilha de Timor e outras ilhas a leste do arquipélago indonesiano, a $E$. urophylla é encontrada em latitudes entre $8^{\circ}$ e $10^{\circ} \mathrm{S}$, com altitudes variando de 400 a 3.000 m. A precipitação anual é de 1.000 a 1.500 mm, com chuvas concentradas no verão. O período seco não ultrapassa 4 meses. A temperatura média máxima é de $32^{\circ} \mathrm{C}$ e a temperatura média mínima situa-se entre 8 e $12^{\circ} \mathrm{C}$. As geadas podem ocorrer em alguns dias do ano, nas regiões de maior altitude.

\section{Características da madeira}

A madeira é considerada medianamente leve e as propriedades de resistência mecânica são moderadas. Tem relativa estabilidade e alta permeabilidade.

\section{Adaptação no Brasil}

No Brasil, é indicada para usos gerais e muito usada em laminação, componentes estruturais para construção civil, caixotes, mourões, escoras, celulose, papel, chapas duras, painéis, lenha e carvão. 
É considerada apta para regiões onde não ocorrem geadas e locais onde haja déficits hídricos severos. É a quarta espécie de eucalipto mais plantada no Brasil, sendo muito utilizada para estudos genéticos e hibridação. Existe, inclusive, um híbrido das espécies E. grandis e E. urophylla, o E. urograndis, que representa $11 \%$ de toda a extensão de eucaliptais plantados em território nacional.

\subsection{Vantagens e desvantagens da cultura do eucalipto}

De acordo com POORE \& FRIES (1985), citados por LIMA (1987), as 20 espécies florestais mais plantadas no mundo são cultivadas em uma ampla gama de condições de solo e clima, desde regiões tropicais equatoriais até regiões subtropicais e semi-áridas, em climas variando do mediterrâneo até o temperado e com altitudes que variam desde o nível do mar até 4.000 metros. Sendo assim, qualquer generalização a respeito dos impactos ambientais do cultivo de uma espécie florestal em grande escala torna-se incabível. É preciso conhecer as condições nas quais a espécie florestal foi avaliada.

O gênero Eucalyptus apresenta uma série de vantagens, dentre as quais destacam-se as seguintes:

- Reduz a pressão sobre as matas nativas;

- Absorve $\mathrm{CO}_{2}$ atmosférico e libera $\mathrm{O}_{2}$;

- Contribui para a regulação do fluxo e qualidade dos recursos hídricos;

- Pode servir como quebra-vento;

- Fornece matéria-prima para indústrias de celulose e papel, chapas, aglomerados, madeira serrada, fibras, entre outras;

- Gera empregos diretos e indiretos;

- Mantém a cobertura do solo através da serrapilheira, diminuindo os riscos de erosão;

- Contribui para a ciclagem de nutrientes. 
A resistência na aceitação do gênero Eucalyptus, por ser exótico, é um dos maiores problemas que esta cultura enfrenta. Outras culturas são empregadas em larga escala no Brasil para as mais diversas finalidades, como laranja, café, milho e soja, sendo que nenhuma destas são nativas do território nacional. Diferentemente destas espécies citadas, o eucalipto não tem finalidade para a alimentação humana. Desempenha, no entanto, outros papéis de importância como um recurso renovável. Além do seu uso para as finalidades já conhecidas, o eucalipto pode poupar as florestas nativas de sua exploração, servindo como uma alternativa de obtenção rápida e homogênea de matéria-prima.

O eucalipto, portanto, ao ser plantado em monocultivo, apresenta uma série de características vantajosas e desvantajosas. Dentre as desvantagens, citadas por alguns autores, estão as seguintes:

- Monocultura; portanto, terá uma menor biodiversidade;

- Alelopatia - algumas espécies do gênero Eucalyptus possuem efeito alelopático, o que retarda e/ou evita crescimento de outras espécies no local;

- Alto consumo de água, ocasionando seca dos solos;

- Espécie de rápido crescimento; portanto, sua madeira fica sujeita a uma série de defeitos, tornando-a de menor qualidade.

\subsection{Usos finais do eucalipto}

O gênero Eucalyptus tem uma larga empregabilidade, sendo a espécie florestal de rápido crescimento mais difundida no mundo. Pode-se citar como usos finais do eucalipto as seguintes atividades e empregos: celulose, papel, chapas, aglomerados, fibra, movelaria, construção civil, postes, mourões, vigas, escoras, colunas, pranchas, esquadrias, instrumentos musicais, assoalhos, paletes, estrados, artigos artísticos, tonéis, estruturas, dormentes, caixotaria, laminação, 
marcenaria, estacaria, contraplacados, forros, construção naval, carrocerias, artigos esportivos, utensílios agrícolas e decoração de interiores, entre outros.

A casca de muitas espécies pode ser utilizada para extração de tanino e as folhas de quase todas as espécies são ricas em óleos essenciais. A produção de mel é um outro produto final de algumas espécies de eucalipto.

O eucalipto pode ter funções também de quebra-vento, ornamentação, proteção de bacias hidrográficas e de recuperação de áreas degradadas, entre outras.

A madeira serrada de eucalipto tem uma vasta aplicabilidade, podendo ser empregada na construção de pontes, pontilhões, barracões, casas e torres, como já foi citado. NAHUZ et alii. (2000), menciona alguns exemplos de construções civis que empregaram a madeira de eucalipto para estes fins, sob a gestão do IPT, através da Divisão de Produtos Florestais:

- Construção de uma passarela para pedestres sobre a Avenida Eliseu de Almeida, localizada no bairro do Butantã, na cidade de São Paulo. A passarela tem $32,4 \mathrm{~m}$ de comprimento e $2,5 \mathrm{~m}$ de largura; sua estruturação foi toda em E. citriodora e o piso em Pinus, sendo tratados com arseniato de cobre cromatado, o qual garante à madeira uma vida útil estimada em 35 anos;

- Estruturação feita por madeiras de eucalipto nos galpões da marcenaria da Divisão de Produtos Florestais, localizados no bairro do Jaguaré, em São Paulo;

- Construção de três prédios destinados ao uso de pesquisadores do Programa Interunidades de Pós-Graduação em Energia (PIPGE), localizado no Instituto de Eletrotécnica e Energia (IEE) da Universidade de São Paulo (USP). Os prédios, que perfazem um total de $675 \mathrm{~m}^{2}$, são construídos com madeira de Eucalyptus grandis. 


\subsection{A madeira}

A madeira é um produto há muito usado para diversas finalidades. Tal importância desta matéria-prima, que nos deu até o nome do país em que vivemos. O Pau-Brasil, espécie arbórea encontrada em toda a faixa da Mata Atlântica, foi o primeiro produto explorado em larga escala pelos portugueses durante o período da colonização. Sua finalidade de uso era, sobretudo, o tingimento de tecidos, com a extração do corante "brasilina". Sua madeira, pesada, dura e muito resistente, era bastante empregada na construção civil, naval e na fabricação de móveis (LEÃO, 2000).

Outras madeiras, além do Pau-Brasil, foram de grande importância econômica para exportação, como o Jacarandá, Cedro, Maçaranduba e Imbuia. Ainda nos tempos coloniais, no Brasil, o uso de madeira para estruturas apoiou-se em algumas espécies nativas, como o Pinho, Peroba, Cedro, Ipê, Jatobá e Cabreúva, além das já citadas. Com a escassez de algumas destas espécies, somando-se a fatores como o custo final do material e as preocupações florestais crescentes, a madeira proveniente de reflorestamento surgiu como uma alternativa, trazendo um número de vantagens e benefícios que podem atender a uma demanda do mercado em qualidade e quantidade.

\subsubsection{Consumo de madeira}

De acordo com a Organização Internacional da Madeira Tropical (ITTO), o Brasil é o maior consumidor de madeiras tropicais do mundo. Seu consumo anual é de 350 milhões de $\mathrm{m}^{3}$ de madeira (REVISTA DA MADEIRA, 2001). Deste montante, aproximadamente 100 milhões de $\mathrm{m}^{3}$ provêm de florestas plantadas, que são em sua maioria de eucaliptos. De acordo com a ARACRUZ ${ }^{24}$, apenas $14 \%$ de toda a madeira consumida no mundo é proveniente de plantios florestais. O restante deve-se à extração de espécies florestais naturais.

\footnotetext{
${ }^{24}$ Disponível na internet <www.aracruz.com.br $>$ s.d.
} 
SMERALDI (1999) relata que as regiões Sul e Sudeste do Brasil (em especial o estado de São Paulo) são responsáveis pelo maior consumo de madeira tropical do mundo. Nestas regiões, importa-se mais que o dobro de madeira que os 15 países da União Européia. De cada 5 árvores cortadas na Amazônia, 1 é destinada ao mercado do estado de São Paulo.

De acordo com a tabela 2.1., pode-se observar que o volume de madeira serrada de espécies nativas consumido no Brasil é mais que o dobro do volume consumido de espécies de árvores plantadas. Acredita-se que o estímulo ao plantio de eucalipto, através do presente projeto, possa encorajar os agricultores, garantindo uma nova fonte de renda com o MDL, além da fonte de renda relacionada à venda da madeira serrada; e, mais que isso, possa reverter lentamente o quadro de consumo de madeiras nativas para fins de serraria.

Tabela 2.1. - Consumo de madeira industrial em toras no Brasil, em 1999 (x 1.000 $\left.m^{3}\right)$.

\begin{tabular}{|c|c|c|c|}
\hline & Nativas & Plantadas & Total \\
\hline Celulose e papel & - & 32.000 & 32.000 \\
\hline Carvão vegetal & 11.800 & 33.400 & 45.200 \\
\hline Lenha Industrial & 16.000 & 13.000 & 29.000 \\
\hline Serrados & 34.000 & 15.100 & 49.100 \\
\hline $\begin{array}{c}\text { Lâminas e } \\
\text { compensados }\end{array}$ & 2.050 & 3.960 & 6.010 \\
\hline $\begin{array}{c}\text { Painéis } \\
\text { reconstituídos }\end{array}$ & - & 5.000 & 5.000 \\
\hline Total & 63.850 & 102.460 & 166.310 \\
\hline
\end{tabular}

* Incluem: Aglomerados, Chapas de fibra e MDF

Fonte: Abracave, STCP, Abipa, Abimci, Bracelpa, SBS, 2000.

Pode-se fazer uso de espécies plantadas com o intuito de diminuir o consumo das espécies nativas para lenha e carvão. Esse não é, no entanto, o foco do presente trabalho, que objetiva estudar o emprego de espécies provenientes de florestas plantadas para fins de madeira serrrada. 
São muitas as espécies nativas utilizadas no mercado madeireiro paulista. A título de ilustração, seguem-se algumas espécies empregadas e suas finalidades:

- Cedro, Pau-Marfim, Peroba - Marcenaria (madeira serrada);

- Mogno - Laminados;

- Garapa - Dormentes;

- Ipê e Jatobá - Pisos e assoalhos;

- Mogno, Freijó, Cerejeira, Cedrorama, Angelim-Pedra - Portas, janelas e guarnições;

- Curupixá, Virola Rosa, Sumaúma, Achichá - Compensados;

- Cedrinho e Peroba - Construção civil.

\subsubsection{A madeira de eucalipto}

Segundo SIMÕES (2001), o gênero Pinus apresenta um crescimento mais lento e possui uma densidade média de $300 \mathrm{Kg} / \mathrm{m}^{3}$ (a $15 \%$ de umidade relativa), enquanto que a densidade da madeira de eucalipto pode variar de acordo com as espécies, de 450 até $1000 \mathrm{~kg} / \mathrm{m}^{3}$.

WATAI (1991) discorre sobre as seguintes desvantagens da madeira de eucalipto:

- É uma madeira de rápido desenvolvimento e, por isso, sujeita à tensões de crescimento que provocam rachamento e empenamento. Características como estas diminuem o preço final do produto, fazendo com que o custo final da cultura torne-se maior;

- A presença de nós é uma outra característica considerada como defeito na madeira e que também leva à queda de valor do produto final;

- A madeira possui uma baixa estabilidade dimensional, ocasionando defeitos na secagem; 
- Presença de madeira juvenil na porção central da tora, que causa baixa resistência mecânica.

A tabela 2.2. apresenta algumas características de madeiras nativas e exóticas, dentre as quais, três espécies de eucalipto. Através desta tabela, podese notar que o eucalipto tem propriedades mecânicas de resistência, muitas vezes semelhantes e até melhores que algumas espécies nativas relacionadas e utilizadas para fins de serraria.

Tabela 2.2. - Comparação das características físicas e mecânicas de algumas espécies nativas e exóticas.

\begin{tabular}{|c|c|c|c|}
\hline Espécie & $\begin{array}{c}\text { Massa específica } \\
\text { parente } \mathbf{( g / \mathbf { c m } ^ { 2 } )}\end{array}$ & $\begin{array}{c}\text { Contração } \\
\text { volumétrica (\%) }\end{array}$ & $\begin{array}{c}\text { Resistência máxima à } \\
\text { flexão estática (MPa) }\end{array}$ \\
\hline $\begin{array}{c}\text { Ipê-Pardo } \\
\text { Tabebuia ochracea }\end{array}$ & 1.01 & 10.9 & 148.5 \\
\hline E. citriodora & 1.01 & 18.5 & 129.4 \\
\hline $\begin{array}{c}\text { Pau-Marfim } \\
\text { Balfourodendron } \\
\text { riedelianum }\end{array}$ & 0.84 & 15.4 & 104.7 \\
\hline E. urophyla & 0.83 & 20.4 & 94.9 \\
\hline E. saligna & 0.69 & 23.4 & 77.4 \\
\hline $\begin{array}{c}\text { Cedro } \\
\text { Cedrela sp }\end{array}$ & 0.53 & 11.6 & 62.7 \\
\hline Pinus elliottii & 0.48 & 10.5 & 47.9 \\
\hline $\begin{array}{c}\text { Caxeta } \\
\text { Tabebuia aassinioides }\end{array}$ & 0.39 & 10.0 & 43.3 \\
\hline Fon & & & \\
\hline
\end{tabular}

Fonte - WATAI, 1991.

\subsubsection{Constituição química da madeira de eucalipto}

A parede celular das fibras da madeira é formada por três componentes principais: celulose, hemicelulose e lignina (VITAL, et al., 1977).

De maneira geral, as madeiras do gênero Eucalyptus são constituídas basicamente de $50 \%$ de celulose, $25 \%$ de hemicelulose e $25 \%$ de lignina (BLAND, 1985). Esta constituição química varia entre as espécies do mesmo gênero e, em menor escala, entre os exemplares da mesma espécie (VITAL, et al., 1977). 
Para formar estes compostos, há uma combinação de alguns elementos químicos. Estes elementos constituem a composição elementar da madeira seca, considerada constante, de maneira geral:

- $50 \%$ de carbono;

- $44 \%$ de oxigênio;

- $6 \%$ de hidrogênio.

Há, ainda, a participação do nitrogênio $(0,1 \%)$ e das cinzas (material inorgânico), com 0,3\%, que são considerados praticamente desprezíveis.

Portanto, o ponto que mais interessa neste ítem ao presente trabalho é o teor de carbono na matéria vegetal, que corresponde a 50\% (BARRICHELO, 1973; FOELKEL, 1977). Significa o mesmo que dizer que 1 tonelada de matéria vegetal contém 0,5 tonelada de carbono.

\subsubsection{Rendimento da madeira serrada}

De acordo com os dados cedidos pela Aracruz, no final do ciclo da cultura do eucalipto, parte da produção é destinada à fabricação de celulose, e o restante, é destinado à produção de madeira serrada. A quantidade referente à celulose e à madeira serrada, bem como o período desta disponibilidade após o plantio, são descritos no capítulo $\mathrm{V}$.

Desde a colheita, até a otenção da madeira serrada, ocorre perda de material em duas etapas. A primeira etapa corresponde ao momento da colheita. Devido ao corte raso e preparo da tora para a operação de desdobro, parte do volume é deixado no campo, sobre o solo. Este volume deixado, e não aproveitado, corresponde ao toco que fica rente ao chão e à galhada e ponta do fuste, não aproveitados para desdobro na serraria. 
A segunda etapa pós-colheita de perda de volume relaciona-se ao desdobro da madeira, na serraria. A esta perda denomina-se rendimento da madeira serrada. Este conceito é uma relação do volume de madeira serrada obtido após o desdobro sobre o volume de tora antes do desdobro. O valor é dado em porcentagem.

$\operatorname{NAHUZ}^{25}$ (2002), indica um rendimento de madeira serrada de $50 \%$ para a madeira de eucalipto, havendo casos excepcionais em que este rendimento possa chegar aos $65 \%$, por conta de uma boa condução no desdobro, aproveitamento da madeira e uma boa calibragem de equipamento. FUJIHARA ${ }^{26}$ (2002), indica um rendimento menor, em torno de $25 \%$ do aproveitamento do eucalipto em serrarias. A Aracruz ${ }^{27}$ trabalha com um rendimento de madeira serrada de $45 \%$. No presente trabalho, os cálculos serão baseados num valor médio dos dados obtidos, considerando-se um rendimento de madeira serrada de $40 \%$.

A perda de volume no desdobro pode ocorrer por conta de uma série de fatores. A regulagem do equipamento, o método de desdobro adotado, a espessura da serra e a escolha das peças a serem aproveitadas são esses fatores que afetam o rendimento, gerando perdas, geralmente inaproveitadas: costaneiras, refilos, pontas, serragem e pó de serra. $O$ restante, referente aos pranchões, vigas e ripas correspondem à madeira serrada a ser contabilizada para os créditos de MDL.

\subsubsection{Durabilidade da madeira}

De acordo com SIMÕES (2001), algumas espécies nativas, como Aroeirado-Sertão, Braúna, Itapicuru-Amarelo, Jacarandá, Cabreúva-Vermelha e Pau-

\footnotetext{
${ }^{25}$ NAHUZ, M.A. Pesquisador da Divisão de Produtos Florestais - IPT/USP. Entrevista concedida em São Paulo, em 02/05/2002.

${ }^{26}$ FUJIHARA, M.A. Consultor em MDL. Consulta feita por telefone, em São Paulo, em 01/005/2002.

${ }^{27}$ AMBROGI, M.S. Gerente de Planejamento Florestal da empresa Aracruz Celulose S.A. Consulta feita por telefone, em São Paulo, em 03/05/2002.
} 
Ferro, sem serem submetidas a tratamento químico, têm uma durabilidade média de 20 anos. Com tratamento, essas espécies podem alcançar uma durabilidade de 40 a 50 anos.

Se comparada às espécies nativas supra-citadas, a madeira de eucalipto tem uma durabilidade muito pequena: entre 2 e 5 anos, se não submetida a algum tratamento. Porém, com o devido tratamento químico, a madeira de eucalipto pode ter uma durabilidade maior.

Foi escolhida para este estudo, a madeira serrada para fins de construção civil e movelaria. Neste caso, a durabilidade do material - portanto, a permanência de carbono nele - é maior se comparada à madeira destinada à lenha, carvão ou até mesmo celulose e papel, onde o carbono retorna mais cedo à atmosfera através da queima ou degradação do produto. Devido à uma maior vida útil, essa madeira estará retendo carbono por mais tempo e dando sua contribuição para o retardo na devolução deste elemento para a atmosfera.

Uma questão de difícil discussão, e que é uma potencial inviabilizadora ou dificultante da validação de muitos projetos florestais para o MDL, é a durabilidade da madeira e a permanência do carbono neste material. Se o objetivo, como é o do presente projeto, é o aproveitamento do produto final para movelaria ou construção civil (finalidades na qual se obtém um produto com maior durabilidade), provar que o carbono está retido no material e que lá permanecerá por muito tempo é um dos pontos problemáticos do projeto.

De acordo com NAHUZ ${ }^{28}$ (2002), não há trabalhos disponíveis que dêem a quantificação exata do número de anos que uma tora de eucalipto possa durar. Este número pode ser muito variável, pois depende de uma série de fatores, como a espécie, a procedência da madeira, os defeitos que esta apresenta, o tratamento recebido após acolheita e finalidade da madeira. 
Existem escalas qualitativas de resistência natural da madeira, como apresentado na REVISTA DA MADEIRA (2001), onde a escala de durabilidade vai de muito durável, durável, moderadamente durável, pouco durável, até não durável. Nesta escala de classificação, está se levando em conta a resistência natural do cerne (camada mais interna do tronco). Mas, não se especifica a equivalência, em anos, a uma espécie de madeira muito durável, por exemplo.

CAVALCANTE (1983) apresenta dados sobre a durabilidade de 182 espécies arbóreas, dentre elas algumas de eucalipto. Neste trabalho, no entanto, as dimensões dos exemplares usados como corpo de prova, não são homogêneas para todas as espécies. Portanto, poucas conclusões comparativas de durabilidade podem ser tiradas, por conta do trabalho citado. Apenas como um exemplo ilustrativo, o autor apresenta a durabilidade de duas espécies de eucalipto aqui discutidas: E. grandis e E. saligna. Para a espécie E. grandis, a dimensão da peça estudada foi de 17,2-25,6 cm (diâmetro do cerne + alburno). A durabilidade indicada desta madeira, no solo, foi entre 9 e 10 anos. Para a espécie E. saligna, a dimensão da peça experimentada foi de 20-30 cm de diâmetro (também do cerne + alburno) e a durabilidade constatada, no solo, foi maior que 1 ano.

São grandes as incertezas quanto à durabilidade da madeira de eucalipto e a permanência do carbono em seu conteúdo. Este ponto é uma das dificuldades para a pronta validação de projetos de reflorestamento que visem a participação no MDL. A questão da incerteza e da permanência do carbono voltará a ser discutida no capítulo $\mathrm{V}$.

${ }^{28}$ Entrevista concedida em 26/02/02, na Divisão de Produtos Florestais - IPT. 


\subsection{Produção nacional, mundial e importância da cultura}

A cultura do eucalipto no Brasil encontrou uma boa adaptação para o seu desenvolvimento. A tabela 2.3. destaca os principais estados produtores e sua área cultivada em hectares.

Tabela 2.3. - Área plantada de eucalipto no Brasil (2000).

\begin{tabular}{|c|c|c|}
\hline Estado & Área (hectares) & Porcentagem (\%) \\
\hline Minas Gerais & 1.524 .000 & 51.6 \\
\hline São Paulo & 574.000 & 19.4 \\
\hline Bahia & 213.000 & 7.2 \\
\hline Espírito Santo & 152.000 & 5.1 \\
\hline Rio Grande do Sul & 116.000 & 3.9 \\
\hline Mato Grosso do Sul & 80.000 & 2.7 \\
\hline Paraná & 67.000 & 2.3 \\
\hline Pará & 46.000 & 1.5 \\
\hline Santa Catarina & 42.000 & 1.4 \\
\hline Amapá & 13.000 & 0.4 \\
\hline Demais estados & 129.000 & 4.4 \\
\hline TOTAL & $\mathbf{2 . 9 5 6 . 0 0 0}$ & $\mathbf{1 0 0}$ \\
\hline
\end{tabular}

Fonte: Revista da Madeira, 2001.

No Brasil, o eucalipto concentra-se majoritariamente na região sudeste, com aproximadamente $80 \%$ de toda a cultura cultivada em larga escala. Nesta região, encontram-se as maiores empresas siderúrgicas, que se utilizam da madeira para carvão mineral; além delas tem-se as indústrias produtoras de celulose e papel.

Mais de 90 países em todo o mundo possuem projetos de reflorestamento com eucalipto, sendo que 58 deles fazem-no em escala comercial (FAO, apud REVISTA DA MADEIRA, 2001).

Pode-se verificar, de acordo com a tabela 2.4, que há plantados atualmente 13.300.000 hectares de eucalipto pelo mundo. O Brasil, com aproximadamente 3 milhões de hectares de eucalipto plantados em seu território, corresponde a 22,5\% do cômputo mundial. Sua área com o plantio do gênero perde somente para a 
Índia, a primeira em produção, com 4.800 .000 de hectares, correspondendo a $36 \%$ de todo o eucalipto cultivado no mundo.

Tabela 2.4 - Área plantada de eucalipto no mundo (2000).

\begin{tabular}{|c|c|}
\hline Região & Área (hectares) \\
\hline Ásia & 6.022 .000 \\
\hline Pacífico & 358.000 \\
\hline América do Norte & 65.000 \\
\hline América Central/Caribe & 60.500 \\
\hline América do Sul & 3.773 .000 \\
\hline África & 1.701 .500 \\
\hline Mediterrâneo & 1.320 .000 \\
\hline TOTAL & $\mathbf{1 3 . 3 0 0 . 0 0 0}$ \\
\hline
\end{tabular}

Fonte: REVISTA DA MADEIRA, 2001.

De acordo com MORA et al. (2000), as plantações florestais geram cerca de 500.000 empregos diretos e 2 milhões de empregos indiretos no Brasil. Em 1998, a receita gerada por este setor foi de U\$S 13 bilhões, contribuindo com 4\% do PIB nacional.

A elevada importância econômica deste gênero para o setor industrial tem também ensejado pesquisas. Em agosto de 2001, foi iniciado o sequenciamento genético do eucalipto. É o sequenciamento da segunda espécie vegetal no Brasil (o primeiro sequenciamento foi o da cana-de-açúcar) e tem grande importância dentro do setor florestal nacional. Quatro empresas florestais (Votorantim, Ripasa, Duratex e Suzano) irão financiar $1 / 3$ da primeira etapa de sequenciamento (com o custo total previsto em US\$ 1 milhão). O restante será financiado pela Fundação de Amparo à Pesquisa do Estado de São Paulo (FAPESP). Na segunda fase de sequenciamento (orçada em US\$ 2 milhões), o setor privado irá participar com $50 \%$ do financiamento. O sequenciamento e a identificação dos genes serão usados no melhoramento das espécies, podendo trazer maior produtividade, melhor absorção de nutrientes e resistência a doenças (MATEOS, 2001).

O Brasil detém ainda a maior e mais complexa rede de experimentos florestais do mundo, denominada Projeto Genolyptus. Seu objetivo básico é 
aumentar a competitividade do gênero no Brasil, através da pesquisa em plantações espalhadas pelo território nacional e as formas de aumento de produção. São ainda objetivos deste projeto, a diminuição da poluição das indústrias ligadas ao setor, e o desenvolvimento de espécies de eucaliptos mais resistentes e adequadas aos seus diferentes usos.

Estão envolvidas neste projeto 12 empresas, 7 universidades e a Embrapa. Os recursos viabilizados são do Fundo Verde-Amarelo, do MCT. Sua primeira fase, prevista para 5 anos e com início em 2001, consumirá cerca de $R \$ 12$ milhões (MCT, 2002). 


\section{Capítulo III}

Introduzida a questão das mudanças climáticas e suas causas, a possibilidade e o potencial de reflorestamento com espécies de eucalipto no Brasil, segue-se uma discussão a respeito do Protocolo de Quioto.

O Protocolo de Quioto será descrito (iniciando-se com o histórico político que antecedeu este documento), bem como seus mecanismos de flexibilização, dando-se ênfase ao MDL, único mecanismo onde cabe a participação brasileira na comercialização de créditos de carbono. Ainda relacionado ao Protocolo, será estudado um caminho a ser tomado para que se estruture um projeto de reflorestamento que tenha como objetivo a participação no MDL. 


\section{As discussões sobre as mudanças climáticas}

\subsection{Histórico}

Para que se entenda o Protocolo de Quioto, deve-se antes conhecer o conteúdo do documento elaborado pela Convenção sobre Mudança do Clima, documento este que antecedeu o Protocolo e deu início a um ciclo anual de reuniões sobre as mudanças climáticas.

Devido às evidências de aquecimento global, em virtude do acúmulo dos GEE na atmosfera, a preocupação com o clima ganhou importância a partir da década de 1980. Ocorreram desde então inúmeras reuniões de ordem internacional sobre as mudanças climáticas, onde foram discutidas as possíveis soluções para evitar ou, ao menos, reduzir a emissão desses gases causadores do efeito estufa. Vale lembrar que o homem tem grande parcela de responsabilidade na emissão destes gases.

Em 1988, a United Nations Environment Programme (UNEP) e a World Meteorology Organization (WMO) estabeleceram o Intergovenmental Pannel on Climate Change (IPCC), grupo formado por cientistas de todo o mundo, incumbidos de pesquisar, avaliar e divulgar as informações disponíveis a respeito das mudanças climáticas. Em 1990, o IPCC divulgou seu primeiro relatório, conhecido como First Assessment Report (FAR), confirmando o problema do aquecimento global. No relatório, o grupo sugere que seja estabelecido um tratado global que direcione e combata o problema.

Esta crescente preocupação ganhou repercussão no Ministerial Declaration of the Second World Climate Conference (outubro/novembro de 1990), em Genebra, e a United Nations General Assembly (UNGA) estabeleceu formalmente o início das negociações de uma convenção sobre mudanças climáticas. Estabeleceu ainda o Integovernmental Negotiating Committe (INC) para conduzir estas negociações. O INC, para estruturar a Convenção sobre Mudanças 
Climáticas, reúne-se pela primeira vez em fevereiro de 1992. Em 9 de maio do mesmo ano, o INC adota a United Nations Framework Convention on Climate Change (UNFCCC - ou Convenção-Quadro das Nações Unidas para as Mudanças Climáticas - CQMC). A Convenção foi aberta na United Nations on Environment and Development (UNCED), conhecida também como "Cúpula da Terra" ou ECO-92, realizada no Rio de Janeiro, em junho de 1992. Até o momento, 186 nações (e a Comunidade Européia) são Partes constituintes da Convenção.

Para ser Parte da Convenção, o país deve ratificar, aceitar, aprovar ou aderir à Convenção. Em 21 de março de 1994, a Convenção sobre Mudança do Clima entrou em vigor. Ao ratificarem a Convenção, as Partes constituintes comprometeram-se com os termos da mesma.

A Convenção sobre Mudanças do Clima (CSMC) gerou um documento que reconhece oficialmente as evidências de mudanças climáticas globais causadas em grande parte pelo homem e a gravidade da questão. Neste documento são propostas algumas ações e diretrizes de início ao combate do aquecimento global. Mais especificamente, a Convenção tem o objetivo de reduzir ou evitar as emissões de gases de efeito estufa, de modo que haja uma adaptação sem grandes perdas da biodiversidade e uma redução dos impactos causados à natureza.

A CSMC é composta por 26 artigos, desmembrados em definições, objetivos, princípios, obrigações e regras determinadas pelos membros da Convenção. A CQMC reconhece no texto que a questão das mudanças climáticas é de responsabilidade comum, mas diferenciada entre os países. Significa que os países desenvolvidos têm uma responsabilidade maior em reduzir suas emissões, já que o desenvolvimento de uma nação, conforme a Convenção-Quadro, está diretamente relacionado às emissões de GEE efetuadas pela mesma. Os países em desenvolvimento não são obrigados a reduzir suas emissões. 
Em virtude disso, os países signatários da Convenção são divididos de forma que possam equalizar suas obrigações na tentativa de reduzir as emissões de GEE. A Convenção determina ainda que as Partes países desenvolvidos devem tomar a iniciativa no combate à mudança do clima, buscando sempre o desenvolvimento sustentável e o auxílio aos países em desenvolvimento, sobretudo aos que estão sujeitos a mais riscos, devido ao aquecimento global. As Partes, portanto, são divididas em Anexo I (países desenvolvidos) e não Anexo I.

Os países do Anexo-I são aqueles considerados de economia desenvolvida e que teriam um compromisso na redução de emissão dos gases causadores do efeito estufa. São eles: Alemanha, Austrália, Áustria, Bélgica, Bulgária, Canadá, Comunidade Européia, Croácia*29, Dinamarca, Eslovênia*, Eslováquia*, Espanha, Estados Unidos da América, Estônia*, Federação Russa*, Finlândia, França, Grécia, Hungria*, Irlanda, Islândia, Itália, Japão, Letônia*, Liechtenstein, Lituânia*, Luxemburgo, Mônaco, Noruega, Nova Zelândia, Países Baixos, Polônia*, Portugal, Reino Unido da Grã-Bretanha e Irlanda do Norte, República Tcheca*, Romênia*, Suécia, Suíça e Ucrânia*.

Os demais países em desenvolvimento e integrantes da ConvençãoQuadro das Nações Unidas para as Mudanças Climáticas são constituintes do não Anexo I.

Cada Parte da Convenção é representada nas sessões por uma delegação nacional, constituida por 1 ou mais oficiais, nomeados para representar e negociar a favor de sua nação.

Em 7 de abril de 1995, ocorre em Berlim a primeira Conferência das Partes (COP), como firmado pela CSMC. É lançada uma nova esfera de negociações em um Protocolo ou outro instrumento legal, que deve incluir um compromisso com prazos estabelecidos e com metas rigorosas de redução de emissão de GEE.

${ }^{29}$ Os países assinalados com o sinal * são aqueles em processo de transição para uma economia de mercado. 


\subsection{Conferência da Partes}

O artigo $7^{\circ}$ da CSMC estabelece a Conferência das Partes (COP), que seria, a partir de então, o órgão supremo da CQMC, tendo a responsabilidade de ministrar reuniões regulares (anuais ${ }^{30}$ ), onde seriam tomadas decisões em prol do avanço no combate às mudanças climáticas. A COP revê a implementação da Convenção e examina os compromissos das Partes sob os objetivos da Convenção, novas descobertas científicas e experiência adquirida no decorrer das implementações políticas das mudanças climáticas.

Outra responsabilidade da COP é a revisão da Comunicação Nacional, documento divulgado por todas as Partes integrantes da Convenção, e que destaca as emissões atuais dos GEE do país, em seus diversos setores. A COP deve ainda rever os relatórios anuais do Comitê Executivo, organizar a distribuição regional e sub-regional das entidades operacionais designadas e pregar sua credibilidade. É função da COP ainda, examinar cuidadosamente a distribuição regional e sub-regional com vistas a identificar barreiras sistemáticas à sua distribuição equitativa, além de cuidar de arranjar fundos para atividades de projetos de MDL, se necessário.

As COP's realizadas até o momento e seus destaques foram as seguintes:

COP 1 - Ocorreu em Berlim (Alemanha), de 28 de março a 7 de abril, em 1995. Foi adotado o Mandato de Berlim, através do qual seriam estipulados limites de emissão dos GEE, principalmente do $\mathrm{CO}_{2}$, bem como a definição do calendário a ser cumprido.

COP 2 - Ocorreu de 9 a 19 de julho de 1996, em Genebra (Suíça). Assinada a declaração de Genebra, contemplando o acordo para a criação de obrigações legais com vistas à redução de GEE ainda a ser implementado na COP 3.

${ }^{30}$ Pode haver convocação para sessões extraordinárias das COP's, sendo realizadas 6 meses após a solicitação ter sido comunicada às Partes. Deve haver uma aceitação de pelo menos $1 / 3$ das Partes constituintes da Convenção. 
Em dezembro de 1995, o IPCC lança o seu segundo relatório (SAR Second Assessment Report), apresentado na COP 2, onde reforça as evidências de aquecimento global e a necessidade de uma forte ação política de combate ou minimização dos problemas causados no meio ambiente.

COP 3 - Ocorreu de 1 a 10 de dezembro de 1997, em Quioto (Japão). Contou com a presença de representantes de mais de 160 países com vistas ao cumprimento do Mandato de Berlim. Foi estabelecido o Protocolo de Quioto.

COP 4 - Ocorreu de 2 a 13 de novembro de 1998, em Buenos Aires (Argentina). Criação do Plano de Ação Buenos Aires, cuja data limite seria o ano 2000. Esse plano era um cronograma para pôr em prática as principais regras e questões técnicas e políticas, bem como os impasses respectivos à implementação do Protocolo.

Durante a COP 4, os EUA assinaram o Protocolo de Quioto, o que representou um passo importante de reconhecimento do problema, embora não tenham ratificado este documento. Para tal, é necessário que o senado americano $^{31}$ aprove o Protocolo.

COP 5 - Ocorreu de 25 de outubro a 5 de novembro de 1999, em Bonn (Alemanha). Houve reuniões técnicas e processo de consulta em cumprimento ao Plano de Ação Buenos Aires.

COP 6 - Ocorreu de 13 a 18 de novembro de 2000, em Haia (Holanda). Não houve concenso entre a maioria, sendo esta conferência suspensa. Os EUA negaram-se a aderir ao Protocolo, alegando que o plano seria prejudicial à economia do país. 
COP 6,5 - Ocorreu de 16 a 27 de julho de 2001, em Bonn (Alemanha). Ao contrário da $\operatorname{COP} 6$, esta conferência foi considerada um sucesso. O Protocolo chega mais próximo à ratificação, mesmo sem o apoio dos EUA.

COP 7 - Ocorreu de 29 de outubro a 9 de novembro de 2001, em Marrakesh (Marrocos). Na COP 7, decide-se facilitar um pronto começo para o MDL. Significa que as Partes da Convenção podem iniciar seus projetos, antes mesmo da ratificação do Protocolo, e comercializar seus respectivos créditos no mercado, desde que estes tenham sido aprovados pelo Comitê Executivo. Foi sugerida também na COP 7 a escolha para os membros do Comitê Executivo, cuja função, dentre outras, seria a de seleção de entidades operacionais.

Foi estabelecido ainda que, mesmo os países que não tenham ratificado o Protocolo, possam participar do Comércio de Emissões, um dos mecanismos de flexibilização do Protocolo. Significa dizer que países como os EUA (que até o momento não pretendem ratificar o Protocolo) podem comercializar as "unidades de redução de emissões" em bolsas de valores ou projetos pilotos, como é o caso da Chicago Climate Exchange (vide ítem 3.8.). Esta facilidade foi criada para que os países que ainda não ratificaram o Protocolo, e caso venham a fazê-lo, iniciem uma comercialização gradativa dos créditos, para uma contabilização futura.

Conferência RIO+10 - A ser realizada de 26 de agosto a 4 de setembro de 2002, em Joanesburgo, na África do Sul. Será uma reunião sobre o meio ambiente, onde serão discutidos os avanços ocorridos nos 10 anos, desde a Cúpula da Terra (Rio92).

31 Os EUA e a Rússia representam juntos mais da metade das emissões referenciadas no Protocolo. Em 1990, os dois países correspondiam a $53,6 \%$ das emissões globais de GEE (BNDES, 1999). 


\subsubsection{Próximas Conferências das Partes}

Mesmo após a ratificação do Protocolo de Quioto, que se espera que ocorra na Conferência $\mathrm{RIO}+10$, os trabalhos da COP prosseguem, pois nestas reuniões são tomadas decisões em relação ao cumprimento das metas entre os países compromissados através dos projetos desenvolvidos e outras atividades designadas já especificadas no ítem 3.2. Seguem-se as próximas reuniões da $\mathrm{COP}^{32}$ :

COP 8 - Deve ocorrer em 23 de outubro a 1 de novembro de 2002, em Nova Delhi, na Índia.

COP 9 - Deve ocorrer de 1 a 12 de dezembro de 2003. A data deve ainda ser confirmada e o local da reunião, determinado.

\subsection{O Protocolo de Quioto}

O Protocolo de Quioto foi apresentado com propostas concretas para o início do processo de redução de emissão (ou estabilização) dos GEE às Partes signatárias da Convenção em 1997, na terceira Conferência das Partes, no Japão.

O Protocolo estabelece a necessidade de redução de emissão dos GEE não controlados pelo Protocolo de Montreal $^{33}$ em 5,2\%, por parte dos países desenvolvidos, considerados grandes emissores destes gases, e relacionados como Partes constituintes do Anexo I do Protocolo, até o período de 2008 a 2012, com base nas emissões do ano de 1990. Os países em desenvolvimento pertencem ao não Anexo I. Por parte destes países, não há compromisso de

\footnotetext{
${ }^{32}$ Disponível na intenet <www.unfccc.int> 26/03/2002.

${ }^{33}$ O Protocolo de Montreal trata de substâncias que destroem a camada de ozônio. Foi adotado em 16 de setembro de 1987 e as substâncias controladas por este Protocolo são: CFC, Halogênio (Brometo, Cloreto e lodeto) Tetraclorometano, HCFC, HBFC, Brometo de Metila e Metilclorofórmio.
} 
redução dos GEE, mas apenas o de auxiliar os países do Anexo I a atingirem as suas metas de redução.

Neste Protocolo, foram propostos três mecanismos de flexibilização Implementação Conjunta, Comércio de Emissões e Mecanismo de Desenvolvimento Limpo - que facilitam as vias econômicas do compromisso de redução de emissão dos GEE por parte dos países desenvolvidos e grandes emissores, através de projetos que reduzam as emissões de GEE. Desses três mecanismos, apenas o MDL tem aplicabilidade no Brasil. Os países desenvolvidos podem compensar suas emissões através da comercialização de CRE's, em projetos de retenção de carbono, realizados nos países em desenvolvimento (ou relacionados no não Anexo I do Protocolo).

Composto de 28 artigos, o Protocolo de Quioto foi o documento redigido de maior importância dentre os tratados acerca das questões relacionadas ao meio ambiente.

Este Protocolo é uma extensão do texto lançado em 1992 pela ConvençãoQuadro sobre Mudanças do Clima. Estabelece políticas e medidas de redução, além dos prazos e comprometimentos entre os países Partes da Convenção.

O Protocolo de Quioto ainda não foi ratificado, mas já ocorre comercialização dos créditos de carbono, ainda que em pequena escala e numa fase experimental, conhecida como fase piloto.

Estes certificados devem ser devidamente contabilizados no final do primeiro período de compromisso entre as Partes integrantes da Convenção. O primeiro período vai de 2000 a 2012 e a contabilização dos créditos será de 2008 a 2012. 
Para entrar em vigor, o Protocolo deve ser ratificado por pelo menos 55 dos países signatários que representem pelo menos $55 \%$ das emissões globais do ano base de 1990 (TETTI, 2001a).

O Presidente da República, Fernando Henrique Cardoso, anunciou, após a reunião de Marrakesh (COP 7), que enviaria ao Congresso Nacional o pedido de ratificação do Protocolo de Quioto. No dia 13/03/2002, o presidente realizou uma cerimônia de assinatura da mensagem encaminhada ao Congresso, pedindo que este fosse ratificado o mais prontamente possível. Pretende-se ratificar 0 Protocolo antes da Conferência RIO+10, a ser realizada em setembro, na África do Sul, onde serão discutidos os avanços feitos acerca do combate às mudanças climáticas, desde a ECO-92 (FREITAS, 2002).

A União Européia (UE), que prevê uma redução de $8 \%$ dos GEE, reuniu os ministros do meio ambiente no dia 04/03/2002, em Bruxelas, e decidiu ratificar o Protocolo. O dia da ratificação será $1^{\circ}$ de junho de 2002. A Dinamarca, que havia pedido uma revisão do percentual de emissões desses gases, comprometeu-se a reduzir suas emissões em 21\%, com base no ano de 1990.

Com isso, a UE espera que os outros países industrializados tomem a mesma iniciativa e ratifiquem o Protocolo até a RIO+10. A UE dirige ainda uma ofensiva para que países como a Rússia, Japão e Canadá tenham o mesmo propósito de ratificar o Protocolo até a Conferência do clima, na África do Sul.

Os Estados Unidos são uma peça chave para a ratificação do Protocolo, pois representam cerca de $25 \%$ das emissões mundiais dos gases de efeito estufa. Aguardava-se uma posição do governo americano desde que o presidente George W. Bush rejeitou o Protocolo de Quioto, por considerá-lo nocivo à economia do país. Foi anunciado em 14 de fevereiro de 2002 um plano alternativo ao tratado internacional de Quioto. A proposta de Bush tem duas frentes: 
- "Iniciativa dos Céus Limpos" (Clear Skies Iniciative), que propõe cortar em $70 \%$ as emissões de três gases poluentes do ar - óxidos de nitrogênio, dióxido de enxofre e mercúrio, até 2018;

- Enfrentar as mudanças climáticas através do atrelamento da redução de emissões dos GEE ao crescimento do PIB americano. O total de GEE emitido por milhão de dólares do PIB deverá ser reduzido em 18\% nos próximos 10 anos. Significa que, das atuais 183 toneladas por milhão de dólares do PIB, espera-se chegar a 151 toneladas em 2012 (ANGELO, 2002a.).

A notícia foi recebida com pouco entusiasmo por ONG's e especialistas do mundo inteiro. Consideram um passo importante o fato de o presidente Bush reconhecer finalmente o problema das mudanças climáticas e propor estratégias alternativas para o combate do aquecimento global. Tal disposição encontra-se, porém, aquém das necessidades e do compromisso estabelecido pelo Protocolo de Quioto. Além do mais, está previsto um crescimento de 30\% no PIB americano em 10 anos e, de 1990 até os dias atuais, os EUA já aumentaram em $11 \%$ as suas emissões (NOVAES, 2002).

\subsubsection{Comitê Executivo}

O Comitê Executivo é um órgão criado sob a autoridade e orientação da COP e que tem como funções:

- Fazer recomendações à COP sobre procedimentos e modalidades para o MDL, quando necessário, bem como emendas ou adições às regras já estabelecidas;

- Aprovar novas metodologias, monitorar planos e limites de projetos;

- Ser responsável pela certificação de entidades operacionais;

- Tornar públicas as informações disponíveis e não confidenciais sobre os projetos de MDL já existentes; 
- Desenvolver, manter e tornar disponíveis ao público um conjunto de regras aprovadas, procedimentos, metodologias e padrões.

O Comitê Executivo é formado por 20 membros, sendo 10 membros titulares e os outros 10 substitutos, com os mandatos variando de 2 a 3 anos. A divisão foi feita da seguinte forma: 3 representantes de países do Anexo I, 3 representantes de países do não Anexo I e 4 representantes das Pequenas Ilhas (GARLIPP, 2001).

O Brasil foi designado na COP 7 como um dos 10 integrantes do Comitê Executivo. A função será exercida pelo ex-presidente da Agência Espacial Brasileira (AEB), Luiz Gylvan Meira Filho, que representará a América Latina e o Caribe (TEIXEIRA, 2001).

O Comitê deve levar em conta as políticas nacionais, e aplicáveis e as circunstâncias específicas nacionais e regionais, tais como: iniciativas de reformas setoriais, disponibilidade local de combustíveis, planos de expansão do setor elétrico e a situação econômica do setor relevante para a atividade do projeto. $\mathrm{O}$ Comitê Executivo deve ainda levar em conta as práticas atuais no país hospedeiro ou na região adequada e as tendências observadas.

\subsubsection{Entidades Operacionais}

Entidades Operacionais são organizações designadas pelo Comitê Executivo e que têm a função de intermediar a COP nas avaliações, verificações e certificações de projetos de MDL (UNFCCC, 2001).

As Entidades Operacionais designadas devem prestar contas à COP através do Comitê Executivo, devendo concordar com as modalidades e decisões aprovadas pela COP. São funções de uma Entidade Operacional: 
- Validar as atividades de MDL propostas;

- Verificar e certificar as reduções em emissões antropogênicas de fontes de gases estufa;

- Conduzir inspeções locais;

- Verificar se a documentação do projeto está de acordo com o requerido e estabelecido pela COP;

- Revisar os resultados do monitoramento, verificando as metodologias das mesmas;

- Recomendar modificações no monitoramento do projeto, caso haja necessidade;

- Fornecer relatório a respeito do projeto de MDL, destinando uma cópia aos participantes do projeto, uma cópia às Partes envolvidas e outra cópia ao Comitê Executivo. O mesmo relatório deve ser disponibilizado ao público.

- Submeter um relatório anual ao Comitê Executivo.

A Entidade Operacional deve provar que não há um conflito real de interesses com os participantes do projeto de MDL para o qual foi selecionada. Tal conduta evitaria ou diminuiria os riscos de fraude.

Uma única Entidade Operacional pode ser designada para cumprir todas as funções de avaliação, registro, monitoramento, validação e certificação do projeto de MDL, ou apenas uma destas etapas.

A escolha de uma Entidade Operacional é feita pelos participantes do projeto de MDL, desde que esta Entidade tenha sido designada pelo Comitê Executivo. Se a Entidade Operacional constata que o projeto de MDL deve ter sua metodologia de base modificada, isto deve ser feito antes da aceitação da atividade para o processo de registro.

Há algumas empresas interessadas em serem designadas pelo Comitê Executivo para as atividades de Certificação de projetos de MDL. A Price 
Waterhouse Coopers, em dezembro de 2001, enviou um documento aos membros da COP, mostrando-se interessada em ser designada como uma Entidade Operacional $^{34}$.

\subsubsection{Comissão Interministerial de Mudança Global do Clima}

No dia 7 de julho de 1999, foi criada a "Comissão Interministerial de Mudanças Climáticas" com o objetivo de articular e prosseguir no Brasil com as decisões tomadas pela CQMC. Esta Comissão deve definir a elegibilidade para os projetos nacionais de $\mathrm{MDL}$, bem como a sua adequação às estratégias nacionais de desenvolvimento sustentável. É composta pelos seguintes Ministérios: Ciências e Tecnologia, Relações Exteriores, Meio Ambiente, Minas e Energia, Agricultura e Abastecimento, Transportes, Orçamento e Gestão, Desenvolvimento, Indústria e Comércio, Projetos Especiais e Casa Civil. Aos ministros de estado da Ciência e Tecnologia e do Meio Ambiente, caberão respectivamente a presidência e a vice-presidência da Comissão.

A Comissão Interministerial tem atribuições, dentre as quais destacam-se a emissão de pareceres, o fornecimento de subsídios para políticas setoriais, as posições do governo nas negociações da Convenção, definição dos critérios de elegibilidade (adicionais àqueles já considerados pelos organismos da Convenção), pareceres sobre os projetos que resultem na redução de emissões e aprovação dos mesmos.

A Comissão pode solicitar a colaboração de órgãos públicos, privados ou entidades que tragam auxílio às suas funções, objetivos e realizações.

A Comissão deve começar a receber projetos de $\mathrm{MDL}$ assim que $\mathrm{O}$ Protocolo for ratificado. Estes projetos devem ser aprovados por escrito, através

\footnotetext{
${ }^{34}$ Disponível na internet <www.unfccc.int $>$ s.d.
} 
de uma carta de aprovação que é submetida ao Comitê Executivo, junto com o relatório de validação.

Existem setores e atividades de interesse prioritários para o âmbito nacional e implantação do MDL que a Comissão Interministerial enumera:

- Ampliação do uso de fontes de energia, como as renováveis;

- Conservação da energia e de aumento da eficiência energética;

- Substituição do uso de recursos energéticos de origem fóssil por fontes energéticas renováveis ou de baixo potencial emissor;

- Melhoria e redução de emissões em sistemas de transporte;

- Co-geração de eletricidade;

- Aumento da oferta energética nacional, através do uso de fontes renováveis, não emissoras ou de baixo potencial de emissão;

- Reflorestamento e recuperação de áreas desflorestadas e/ou degradadas, compatíveis com as definições nacionais e regionais de uso do solo e áreas de proteção.

O quadro institucional brasileiro para o gerenciamento da implementação dos assuntos relativos à Convenção das Mudanças Climáticas, Protocolo de Quioto e MDL, pode ser representado através da seguinte figura: 
Figura 3.1. - Quadro institucional brasileiro para gerenciamento de implementação dos assuntos referentes à Convenção sobre Mudança do Clima.

Presidência da República

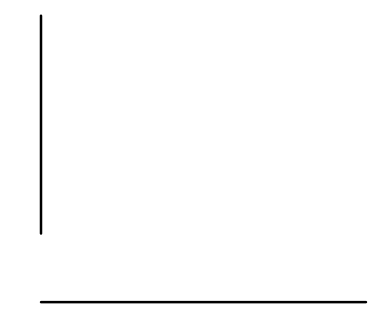

Fórum Nacional de

Mudanças Climáticas

Comissão Interministerial

de Mudanças Climáticas

Ministério da Ciência e Tecnologia

Secretaria Executiva

Fonte: TETTI, 2001a.

A Secretaria Executiva é um órgão subordinado da Comissão Interministerial. Sua função é avaliar, verificar e aprovar os projetos de MDL, desde que estes estejam nos moldes de um projeto de MDL.

O Fórum Nacional de Mudanças Climáticas, criado em 20 de julho de 2000 por decreto presidencial, tem a função de promover o debate e propagar os conhecimentos à respeito das mudanças climáticas para toda a sociedade.

Após passar por aprovação do parecer pela Comissão Interministerial, o projeto é levado à Presidência da República, que o assina se estiver de acordo com o desenvolvimento do mesmo. A aprovação do parecer do projeto pela Comissão Interministerial e pela presidência da república é um sinal de reconhecimento do projeto e sua conformação, diante do Comitê Executivo. 


\subsubsection{Comunicação Nacional}

É o registro sistemático e periódico das emissões e sumidouros de GEE de um determinado país. A Convenção-Quadro estabelece a necessidade de todas as Partes da Convenção elaborarem, publicarem e disponibilizarem os seus inventários. Estes devem estar de acordo com a metodologia estabelecida pelo IPCC, com base em emissões antrópicas, por fonte e definição de formas de captura de todos os gases de efeito estufa não controlados pelo Protocolo de Montreal (UNFCCC, s.d.).

O Inventário Brasileiro das emissões antrópicas ainda não se encontra disponível em versão integral. O inventário, que pode ser encontrado na página da internet do Ministério das Ciências e Tecnologia ${ }^{35}$, levantou um conjunto de dados para os itens:

- Setor energético;

- Indústria;

- Solvente;

- Setor agropecuário;

- Mudanças no uso da terra e florestas;

- Conversão de pastagens e florestas;

- Acima do solo (estimativas por imagens de satélite);

- Amazônia Legal;

- Cerrado;

- Caatinga;

- Pantanal;

- Mata Atlântica;

- Abaixo do solo;

- Variação nos estoques de florestas e outras biomassas lenhosas (florestas plantadas);

- Abandono de terras cultivadas (rebrota); 
- Emissões de metano dos reservatórios de hidroelétricas;

- Tratamento de resíduos.

O Inventário Nacional é um pré-requisito para que o país ratifique sua adesão ao Protocolo no Congresso Nacional. CAMPANILI (2002) afirma que o inventário está quase pronto e, segundo o presidente do IBGE, Sérgio Besserman Viana, o documento deve ser apresentado ao Congresso antes da conferência RIO+10, a ser realizada em setembro de 2002. De acordo com o MCT, trabalham na elaboração deste inventário mais de 500 técnicos e pesquisadores de 100 instituições públicas e privadas.

CAMPANILI (2002), afirma ainda que o Brasil deve situar-se entre 1 dos 10 maiores emissores mundiais de gases de efeito estufa, por conta das queimadas da Amazônia.

\subsubsection{Adapatação, Capacidade de Construção e Transferência Tecnológica}

Existe um custo para a implementação de um projeto de MDL. Pela recente criação e pelo ainda não desenvolvimento de metodologias para projetos florestais, os assuntos relacionados ao Protocolo não sofreram a devida divulgação para a sociedade como um todo, para que se tomasse conhecimento da questão e do papel que pode ser exercido pelo Brasil dentro deste quadro.

Para que um país possa participar do Protocolo através de projetos, é necessária uma adaptação, ou seja, um conjunto de medidas tomadas para a sua conformação aos efeitos negativos do clima.

Denomina-se construção de capacidade, o treinamento, a divulgação da questão relacionada às mudanças climáticas, a formação de pessoal que desenvolva inventários de emissões, adaptação, treinamento e conscientização

\footnotetext{
${ }^{35}$ Disponível na internet <www.mct.gov.br>
} 
pública, além da transmissão de novas informações relacionadas à implementação de projetos de $\mathrm{MDL}$, bem como projetos que já tenham sido certificados (MONZONI, 2000). A construção de capacidade é uma etapa necessária e indispensável para todo e qualquer país relacionado na Convenção, antes mesmo que sejam estabelecidas atividades de redução de emissões de GEE.

Transferência tecnológica é a transferência de conhecimento técnico necessário à implementação das disposições da Convenção, com o objetivo de redução líquida de emissão dos GEE. A transferência inclui investimentos em eficiência energética, desenvolvimento de fontes renováveis de energia e técnicas de sequestro de carbono. É parte do compromisso dos países desenvolvidos possibilitar esta transferência tecnológica aos países em desenvolvimento.

Está previsto no texto da CQMC (artigo 4, parágrafo 4), que os países desenvolvidos devem auxiliar os demais países com os custos de adaptação. No Brasil, as atividades de adaptação e capacidade de construção estão sendo desenvolvidas pela Comissão Interministerial, conforme visto no item 3.3.3.

\subsubsection{Mecanismo Financeiro}

Foi estabelecido pela CSMC, um Mecanismo Financeiro (MF), com o objetivo de prover fundos para doação ou base de concessão, para auxiliar os países em desenvolvimento a implementar a Convenção.

A Convenção nomeou a Global Environment Facility (GEF) como gerenciadora das regras, numa base provisória, em 1996. A COP, na sua segunda sessão, adotou um memorando de entendimento com o GEF de suas regras e responsabilidades respectivas. Em 1998, a COP incumbiu o GEF de seu papel dentro da Convenção, sujeito a uma revisão a cada 4 anos. 
O GEF foi formado em 1991 pelo Banco Mundial (World Bank), a UNDP e a United Nations Environment Programme (UNEP). Iniciou uma fase piloto em 1994, no auxílio a projetos em países em desenvolvimento, que trouxessem benefícios ambientais globais, não só na área de mudanças climáticas, mas também em biodiversidade, proteção da camada de ozônio e águas internacionais. Desde 1991, o GEF alocou um total de 7,1 bilhões de dólares em atividades relacionadas às mudanças climáticas. No período de julho de 1999 a junho de 2000 , o total de financiamento para projetos de mudanças climáticas excedeu US\$1,424 bilhões, tendo o GEF provido US\$ 199 milhões em financiamento (UNFCCC, 2002).

O MF é de responsabilidade da COP e decide as políticas de mudanças climáticas, prioridades e os critérios para financiamento e elegibilidade dos projetos. Portanto, a COP provê orientação política regular ao MF em seus projetos de mudanças climáticas, baseado no Corpo Subsidiário de Implementação.

O GEF também irá gerenciar os três fundos - Fundo Especial de Mudança Climática (The Special Climate Change Fund), Fundo dos Países Menos Desenvolvidos (The Least Developed Countries) e o Fundo de Adaptação (The Adaptation Fund) - providos pelo acordo de Bonn e adotados na COP 6,5.

No Brasil já houve a iniciativa por parte do governo em financiar, embora em pequena escala, projetos de pesquisa relacionados a atividades de MDL. Foi lançado em 2001, um edital com o objetivo de dar apoio direto e descentralizado a projetos-piloto em bases locais, visando a geração de conhecimento técnico, científico e local de projetos de MDL. Um projeto de cooperação técnica foi firmado entre o governo brasileiro e o governo do Reino dos Países Baixos. A disponibilização dos recursos é canalizada através do Fundo Nacional do Meio Ambiente (FNMA). O edital é composto pelos seguintes itens:

- Estudo de viabilidade de Projeto voltado à adoção de MDL;

- Implementação de Projeto de Ação Climática. 
Estes dois itens podem abarcar projetos relacionados à energia renovável, florestamento e reflorestamento. Foram previstos $\mathrm{R} \$ 1.050 .000$ de recursos para estes projetos. As análises das propostas foram estipuladas até o final de fevereiro e a divulgação dos resultados, em março de 2002.

\subsection{Mecanismos de Flexibilização}

Há países que têm sua matriz energética baseada na queima de combustíveis fósseis. De acordo com FUJIHARA ${ }^{36}$ (2002), o Japão, que é um dos países relacionados no Anexo I, tem a sua matriz energética dividida da seguinte forma: $20 \%$ correspondem à energia nuclear e o restante, $80 \%$, à termelétricas à base de carvão mineral. Como reduzir estas emissões dos gases provenientes da queima de combustíveis fósseis, sem que o desenvolvimento do país seja afetado?

Para auxiliar os países do Anexo I a atingirem as suas metas de redução previstas na Convenção, o Protocolo de Quioto sugere três mecanismos de flexibilização: Implementação Conjunta, Comércio de Emissões e Mecanismo de Desenvolvimento Limpo. Através destes mecanismos, as Partes da Convenção podem desenvolver projetos florestais ou de eficiência energética, visando a redução de emissão dos GEE e possibilitando uma comercialização de créditos destes gases, de modo a compensar suas metas. Deste modo é possível que os países do Anexo I continuem seu desenvolvimento, sem que a matriz energética seja afetada, ou mesmo, sem que as emissões de GEE nestes países sejam reduzidas.

A seguir são descritos os três mecanismos, dando-se destaque ao MDL, mecanismo proposto pela delegação brasileira e o único que concebe a participação de países em desenvolvimento dentro do Protocolo de Quioto. Nos

\footnotetext{
${ }^{36}$ FUJIHARA, M.A. Consultor em MDL. Palestra proferida na Faculdade Getúlio Vargas, em São Paulo, em 18/03/2002.
} 
dois primeiros mecanismos de flexibilização, é possível a participação apenas dos países desenvolvidos.

A unidade de contabilidade para as reduções de emissões em projetos florestais é feita através de CER's - Certified Emission Reduction, ou Certificados de Redução de emissões. Essa forma de comercialização é descrita com maior profundidade no item 3.6., por se tratar da forma de comercialização do carbono em projetos de MDL.

O Protocolo considera ainda mais uma flexibilização, já prevista na Convenção, denominada "Bolha", onde diversos países podem cumprir suas obrigações conjuntamente como se houvesse uma grande bolha envolvendo-os.

\subsubsection{Implementação Conjunta}

A Implementação Conjunta (ou Joint Implementation) corresponde ao artigo 6 do Protocolo de Quioto. Neste mecanismo, segundo o Protocolo, "qualquer Parte inclusa no Anexo I pode transferir para ou adquirir de qualquer outra dessas Partes, unidades de redução de emissões resultantes de projetos visando a redução das emissões antrópicas por fontes ou o aumento das remoções antrópicas por sumidouros de gases de efeito estufa em qualquer setor da economia".

\subsubsection{Comércio de Emissões}

Artigo 17 do Protocolo de Quioto, o Comércio de Emissões (ou Emission Trading) é um mecanismo possível de ser realizado somente entre países desenvolvidos. De acordo com o Protocolo, "as Partes incluídas no Anexo I podem participar do comércio de emissões com o objetivo de cumprir os compromissos 
assumidos sob o artigo 3." Este artigo $3^{\circ}$ estabelece os compromissos quantificados de limitação e redução de emissões para as Partes da Convenção.

Po este mecanismo, o país que alcançou e excedeu sua meta de redução de emissão, ou seja, que tenha obtido mais créditos que o estabelecido pelo Protocolo, pode comercializar esta quantia excedente para outros países que ainda não a tenham alcançado.

\subsubsection{Mecanismo de Desenvolvimento Limpo}

Constituindo $\circ 12^{\circ}$ artigo do Protocolo de Quioto, o Mecanismo de Desenvolvimento Limpo (MDL ou Clean Development Mechanism - CDM) foi desenvolvido a partir de uma proposta brasileira que sugeria inicialmente a formação de um fundo de Desenvolvimento Limpo, no qual os países de grande emissão, que não conseguissem reduzir suas emissões acordadas entre as partes, deveriam dispor de verba para este fundo, seguindo-se o princípio "poluidor-pagador". Em Quioto, a idéia do fundo foi transformada em mecanismo, passando a ser chamado de Mecanismo de Desenvolvimento Limpo.

Neste mecanismo de flexibilização, os países do Anexo I podem desenvolver projetos de redução de emissão dos GEE nos países do não Anexo I para cumprirem suas metas de redução estabelecidas pelo Protocolo de Quioto. Desta forma, promove-se redução de emissões dos GEE em um país não Anexo I para se garantir a não redução do GEE em um país do Anexo I. Ou seja, de acordo com o Protocolo de Quioto, os países do Anexo I podem continuar emitindo os gases de efeito estufa, desde que compensem essas emissões com a participação em algum projeto que reduza a emissão desses gases; ou com a comercialização de certificados de projetos que tenham esse mesmo objetivo, dentro das metas estabelecidas pelo Protocolo. 
Se um projeto de MDL não é aceito, este pode ser reconsiderado para a validação e registro, mediante revisões apropriadas, devendo seguir os moldes estabelecidos para validação e registro.

Para obter registro, validação e certificação, um projeto MDL deve oferecer benefícios reais, mensuráveis e de longo prazo (dentro dos propósitos da Convenção). Deve ainda representar uma redução de emissões que, na ausência do projeto, seria inexistente.

No MDL não há penalidades para as ações antecipadas. Pelo contrário, há um incentivo para ação imediata no início de atividades que reduzam as emissões de GEE, para que os créditos relativos aos projetos possam futuramente ser contabilizados no período de compromisso respectivo.

De acordo com o Fundo Brasileiro de Desenvolvimento Sustentável (FBDS), são aplicações potenciais dos projetos para o MDL:

- Eficiência energética (eletricidade e combustíveis fósseis na indústria, no transporte e em usos públicos);

- Planejamento urbano para a redução de emissão de combustíveis;

- Fontes alternativas de energia: cogeração, gás natural, geração de energia de pequeno porte (pequenas e micro-centrais hidroelétricas), energia eólica, solar térmica, fotovoltaica e biomassa;

- Manejo sustentável de resíduos industriais urbanos e rurais;

- Reflorestamento;

- Recursos hídricos, matas ciliares e compensação ambiental.

O mercado do MDL é um setor dentro da política ambiental que pode trazer bons frutos ao Brasil. Estima-se que este mecanismo possa movimentar mundialmente cerca de US\$30 bilhões por ano (TEIXEIRA, 2001). 


\subsection{Uso da terra, Mudança do uso da terra e Reflorestamento}

As atividades de Uso da terra, Mudança do uso da terra e Reflorestamento (Land Use, Land-use Change and Forestry - LULUCF) são aquelas relacionadas às reduções de emissões de GEE, para atividades de florestamento e reflorestamento, como definido pela COP. Para serem aceitas no MDL, devem seguir alguns princípios básicos:

- O teor destas atividades deve basear-se em ciência sólida, já comprovada;

- Devem ser usadas metodologias consistentes ao longo do tempo para estimativa e relato de tais atividades;

- A mera presença de estoques de carbono deve ser excluída da contabilidade da redução das emissões;

- A implementação das atividades LULUCF deve contribuir para a biodiversidade e o uso sustentável de recursos naturais.

As atividades LULUCF podem ser empregadas somente em terras que, desde 31 de dezembro de 1989, sejam pastagens ou terras abandonadas, sem a presença de florestas. Essa barreira surgiu para que se evitasse o desmatamento de áreas para o emprego de reflorestamento e, posteriormente a participação dentro do MDL.

A contabilização de emissões de GEE antropogênicas por fonte e remoções por sorvedouros resultantes de atividade de LULUCF, devem começar com o início da atividade ou o início do período de compromisso, aquele que vier mais tarde.

A metodologia para as atividades de florestamento e reflorestamento ainda não foi regulamentada. Espera-se que sua regulamentação seja concluída na COP 9 , em $2003^{37}$.

\footnotetext{
${ }^{37}$ MIGUEZ, J.D.G. Secretário Executivo da Comissão Interministerial de Mudança Global do Clima. Consulta via internet, em 27/02/2002.
} 


\subsection{Certificados de Redução de Emissões}

Os certificados de redução de emissões são a forma de comercialização do carbono retido (ou evitado) nos projetos de MDL entre as Partes da Convenção.

O CRE é uma unidade publicada de acordo com as definições do Protocolo de Quioto, sendo emitido pelo Comitê Executivo e correspondendo a 1 tonelada de dióxido de carbono equivalente. Segundo FUJIHARA ${ }^{38}$ (2002), o valor pago por tonelada do carbono para projetos florestais de MDL é variável e tem uma cotação atual está entre U\$ 4 e U\$7.

O valor a ser pago pelo certificado de um projeto MDL está diretamente relacionado com as incertezas que este apresenta. Em outras palavras, quanto maior a incerteza de um projeto, menor será o valor a ser pago pelos certificados do mesmo. Por este motivo, os projetos florestais partem com um valor médio da tonelada de carbono mais baixo, se relacionados a projetos não florestais. Em um projeto florestal, as incertezas quanto à permanência do carbono são maiores.

Cada certificado deve conter, além de um número de série, os seguintes elementos:

- Período de compromisso para o qual o certificado foi emitido;

- Parte de origem: a Parte que hospedou o projeto de MDL;

- Tipo: deve identificar a unidade como um CRE;

- Unidade: um único número para o período de compromisso do CRE e a Parte de origem;

- Identificador do projeto: um número único para a atividade de projeto MDL para a Parte de origem.

\footnotetext{
${ }^{38}$ FUJIHARA, M.A. Consultor em MDL. Palestra proferida na Faculdade Getúlio Vargas, em São Paulo, em 18/03/2002.
} 
A emissão dos certificados é feita pelo Comitê Executivo e dá-se somente após a verificação e certificação do projeto por parte da Entidade Operacional designada.

\subsection{Ciclo de um projeto de MDL}

Para haver comercialização dos créditos de carbono de um projeto de MDL, este deve oferecer benefícios de longo prazo, reais e mensuráveis, com o propósito de redução das emissões de GEE, além de apresentar um desenvolvimento sustentável em seu processo.

Para tanto, é necessário que este projeto passe por uma série de etapas, denominadas ciclo do projeto. $\mathrm{O}$ ciclo de um projeto de MDL é constituído de 5 etapas, desde a apresentação do projeto ao Comitê Executivo até a emissão dos certificados, feita também pelo Comitê Executivo. O ciclo de um projeto MDL pode ser representado pelo seguinte fluxograma: 
Figura 3.2. - Ciclo de um projeto de MDL.

Projeto

Validação/Registro

Monitoramento

Verificação/Certificação

Emissão

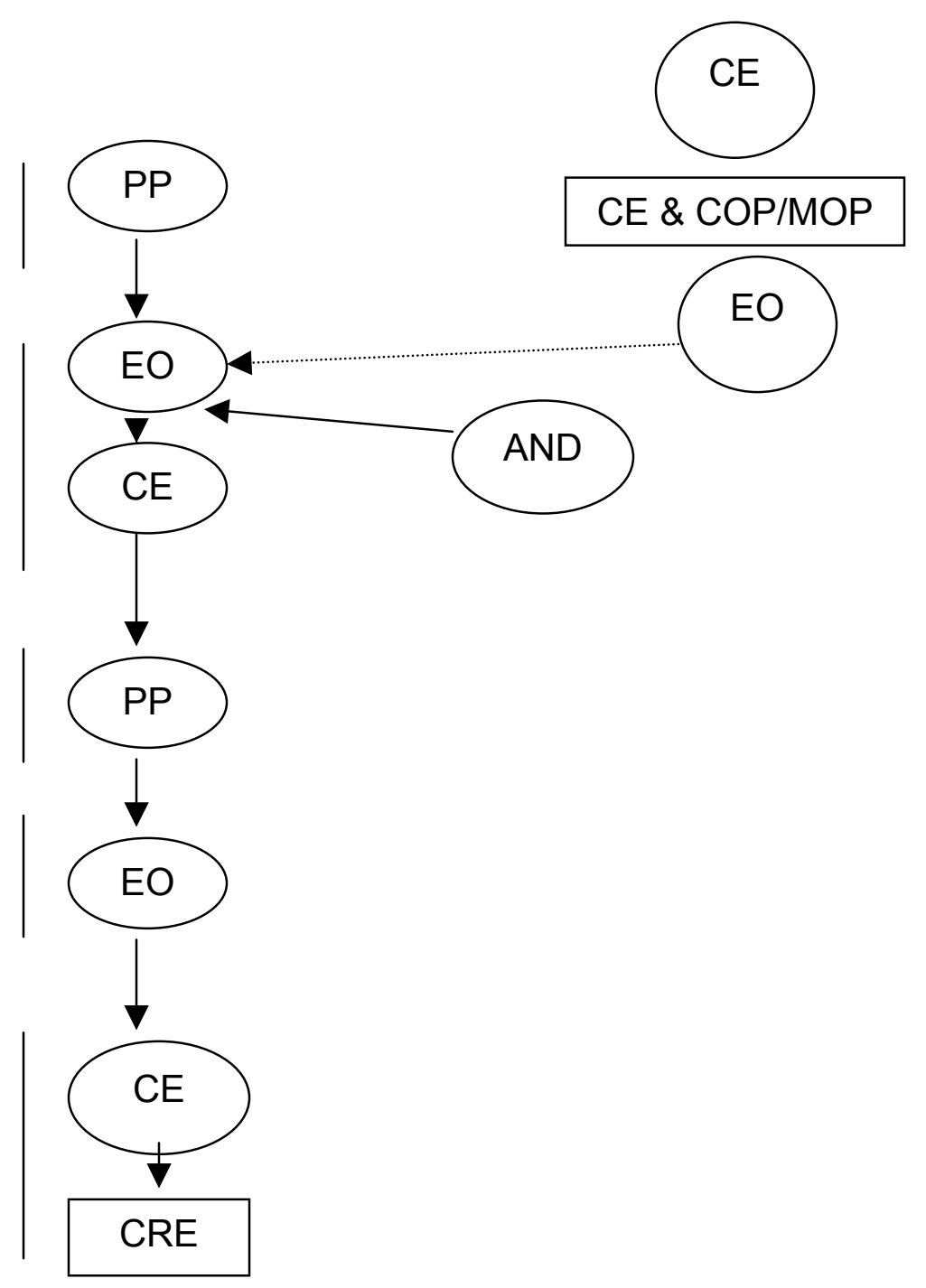

Legenda:

PP - Participantes do projeto

EO - Entidade Operacional

CE - Comitê Executivo

AND - Autoridade Nacional designada

COP/MOP - Conferência das Partes/Membros das Partes

CRE - Certificados de Redução de Emissões

Fonte: UNFCCC, 2002. 
O projeto, ao candidatar-se à participação no MDL, é apresentado ao Comitê Executivo, que por sua vez designa uma Entidade Operacional para estudar os moldes do projeto. Se estes estiverem de acordo com o conjunto de regras do Comitê Executivo, o projeto passa pelas etapas de validação e registro. Há a participação de uma autoridade nacional designada, cuja função, dentre outras, é a de aprovação do projeto para participação no MDL.

O monitoramento é a etapa seguinte, sendo feito pelos participantes do projeto sob a orientação do Comitê Executivo.

A verificação e certificação do projeto são feitas pela Entidade Operacional, desde que os participantes do projeto tenham feito o monitoramento e desde que o monitoramento tenha seguido as regras acordadas entre os participantes do projeto e a Entidade Operacional.

Após as etapas de verificação e certificação, é feita a emissão do certificado pelo Comitê Executivo. Isto, somente após a Entidade Operacional certificar por escrito para o Comitê que o projeto foi devidamente monitorado e contribuiu para a redução de emissões dos gases de efeito estufa, conforme o esperado.

Todas as etapas descritas a seguir foram retiradas da $7^{\text {a }}$ Conferência das Partes, em Marrakesh, em 2001.

\subsubsection{Linha de base}

Para ingressar no MDL, todo projeto deve apresentar uma Linha de Base. A Linha de Base (Baseline) é um cenário que representa razoavelmente as emissões antropogênicas de fontes de gases estufa que ocorreriam na ausência da atividade de projeto proposta. Esta deve ser estabelecida pelos participantes do projeto e deve ser apresentada de maneira transparente, levando-se em conta 
a escolha das aproximações, suposições, metodologias, parâmetros, fonte dos dados e adicionalides, incluindo as incertezas do projeto.

Na Linha de Base do projeto, devem ser apresentados dois cenários: o primeiro cenário deve descrever as emissões antes do projeto; o segundo, as reduções das emissões após a instalação do projeto.

Para projetos florestais, pode haver uma contabilidade do conteúdo de matéria (e consequentemente do carbono nela retido) da parte aérea e subterrânea da floresta. A parte aérea corresponde ao tronco, à copa (ramos e folhas) e à serrapilheira. A parte subterrânea corresponde às raízes das árvores e ao carbono retido no solo. Quanto maior a abrangência nesta contabilidade, maiores serão os custos, pois em cada caso deve ser provado que o carbono está presente e retido no material.

A Linha de Base pode ser feita por uma Entidade Operacional ou pelos integrantes do projeto. O custo desta operação é estimado ${ }^{39}$ em US\$30.000.

\subsubsection{Validação}

É o processo de avaliação independente de uma atividade de MDL por uma Entidade Operacional designada.

\subsubsection{Registro}

O registro é a aceitação formal por parte do Comitê Executivo de um projeto validado como um projeto de MDL. É um pré-requisito para a verificação, certificação e promulgação dos certificados deste projeto. 


\subsubsection{Monitoramento}

Deve constar no esboço do projeto, um plano de monitoramento. Neste plano, deve haver a coleção de todos os dados de relevância do projeto para que a Entidade Operacional possa acompanhar o andamento das atividades e verificar a precisão dos dados relatados. O plano de monitoramento pode ser baseado em uma metodologia de monitoramento já existente ou em uma nova metodologia. $A$ Entidade Operacional pode sugerir a metodologia mais adequada às circunstâncias do projeto, que tenha sido aplicada em outro projeto com sucesso. Tal metodologia deve ainda refletir uma prática de bom monitoramento, adequada ao tipo de projeto de MDL.

\subsubsection{Verificação}

A verificação é a revisão independente, periódica e posterior de um projeto de MDL pela Entidade Operacional designada.

\subsubsection{Certificação}

A certificação é a garantia por escrito, feita pela Entidade Operacional designada de que, durante um período de tempo específico, o projeto de MDL atingiu as reduções de emissões de GEE, como verificado.

\subsubsection{Emissão do certificado}

O certificado é emitido pela empresa que gerencia o projeto, sob a autorização do Comitê Executivo. Isto somente quando o projeto for verificado e

\footnotetext{
${ }^{39}$ FUJIHARA, M.A. Consultor em MDL. Consulta feita por telefone, em 1/05/2002, em São Paulo.
} 
certificado por parte da Entidade Operacional designada, afirmando que a atividade de MDL está dentro das conformidades verificadas, tendo seguido o procedimento de monitoração acordado entre a Entidade Operacional e as Partes integrantes do projeto.

\subsection{O mercado do Carbono}

A comercialização dos créditos de carbono deve ocorrer nas bolsas de valores, a fim de que os países do Anexo I possam cumprir suas metas de redução estabelecidas no Protocolo de Quioto. A comercialização destes créditos, como já foi dito antes, dá-se na forma dos Certificados de Redução de Emissões.

Por não haver ainda grande quantidade de créditos a serem comercializados (pelo fato de o Protocolo ainda não ter sido ratificado), as operações de compra e venda dos certificados estão passando por uma fase piloto. Esta etapa experimental deve se estender até a ratificação do Protocolo, pois a partir daquele momento, o volume de transação de certificados deve aumentar consideravelmente.

Foi estabelecido em Chicago, na segunda metade de 2001, um plano piloto de comércio voluntário de créditos provenientes de emissões evitadas de GEE. Este plano, conhecido como Chicago Climate Exchange, está sendo desenvolvido em alguns estados do meio-oeste dos EUA, para se experimentar sua viabilidade e posterior aplicação em escala global. Esse plano piloto trabalha com créditos de diferentes setores, além de auxiliar na determinação do preço a ser pago por estes certificados. O Chicago Climate Exchange, também poderá ajudar a desenvolver um padrão para o monitoramento de emissões, condução das trocas e comercialização dos créditos, necessários para um mercado bem estruturado.

Este estudo é proposto para iniciar em 7 estados do meio-oeste dos EUA Illinois, Indiana, Iowa, Michigan, Minnesota, Ohio e Wisconsin - incluindo projetos de emissão reduzida do Brasil e expansões ao longo do tempo. Neste plano, está 
prevista a expansão do mercado piloto em 2003, para o restante dos EUA, além de Canadá e México. Em 2004, o mercado piloto pretende se expandir para outros países. Além de organizações não-governamentais, mais de 25 empresas dispuseram-se a participar desta fase piloto. A relação das empresas participantes do Chicago Climate Exchange está relacionada no anexo deste trabalho.

O Banco Central brasileiro estima que o volume interno de negociações dos créditos de carbono, seja de US\$ 60 milhões, após a ratificação do Protocolo de Quioto (GAZETA MERCANTIL, 2002).

\subsection{Quantificação do carbono em uma floresta de eucalipto}

Quantificar o carbono em uma floresta é umas das questões mais complexas travadas entre especialistas, pois envolve fatores externos como a variação do clima, o perfil do solo, a temperatura local e o tipo de vegetação que lá se encontra. Para uma floresta de eucalipto, esta operação torna-se um pouco mais simples, por tratar-se de uma monocultura onde se espera uma produtividade homogênea, de acordo com a variedade cultivada e com os dados para o cultivo que se dispõe da região. Mas, continuam as variáveis de solo, clima, temperatura, enfim, da interação da floresta com o meio.

O Experimento de Grande Escala da Biosfera-Atmosfera na Amazônia (LBA) é um projeto de US\$80 milhões, que envolve pesquisadores da América Latina, Estados Unidos e Europa. Neste projeto, foram distribuídas 12 torres com 55 metros de altura cada, a um custo unitário de aproximadamente US\$200 mil. Estas torres, cujo topo foi projetado para ficar entre 20 e 30 metros acima do dossel da floresta, têm a função de medir o fluxo de dióxido de carbono na floresta diariamente. O sensores localizados no topo da torre têm capacidade de medir dez vezes por segundo a concentração de $\mathrm{CO}_{2}$ que circula na região dos dosséis. Estes fluxos de dióxido de carbono não estavam sendo corretamente medidos. Acreditava-se que a floresta Amazônica sequestrava de 5 a 8 toneladas por 
hectare de carbono anualmente. Uma nova revisão destes números aponta uma redução para 2 toneladas anuais. Paulo Artaxo, do Instituto de Física da USP (IF/USP) e um dos coordenadores do projeto LBA, acredita que esse valor esteja até próximo de zero (PIVETTA, 2002). Este experimento, de grande complexidade, tem o objetivo de medir os fluxos de $\mathrm{CO}_{2}$ entre a floresta e o meio, e também, de aferir a quantidade de carbono retida por hectare.

As florestas, quando atingem o equilíbrio, têm um balanço praticamente nulo em relação à entrada e saída de carbono de sua biomassa. Ou seja, a quantidade sequestrada de carbono durante o dia no processo da fotossíntese é praticamente a mesma liberada durante o processo de respiração. Em florestas em desenvolvimento, a absorção de dióxido de carbono é maior até que se atinja também a maturidade da floresta. A idade em que uma floresta atinge a sua maturidade (ou estabilização) é variável de acordo com o tipo de formação florestal (heterogênea ou mista) e as espécies envolvidas (de crescimento rápido ou lento).

Para a estimativa de fitomassa de uma floresta existem métodos práticos, que vão desde aqueles conhecidos como métodos de análise destrutiva e não destrutiva até os métodos de estimativa através do processamento digital de imagens fornecidos por satélite. A adoção de cada método é feita conforme a formação vegetal e a disponibilidade de capital. Por se distanciar do foco do presente estudo, a descrição e caracterização dos métodos de estimativa de fitomassa não serão abordados.

De acordo com o MCT (2001c.), a quantidade total de carbono estimada em uma árvore de eucalipto pode ser dividida da seguinte forma: tronco: $65 \%$, copa: $13 \%$ e raiz: $22 \%$. Pode-se observar que o tronco corresponde a mais da metade da biomassa de uma floresta de eucalipto. Desprezar a copa e as raízes para a contabilização do carbono em uma floresta de eucalipto seria um desperdício, se não fosse a dificuldade de aferição e comprovação do conteúdo destes últimos. Além do mais, a durabilidade pode ser mais facilmente aferida em relação ao 
tronco, uma vez que, após a colheita, a copa ou é queimada ou sofre processo de decomposição no local (devolvendo o carbono à atmosfera). As raízes permanecem no solo, também em processo de decomposição.

Serão desenvolvidos somente os cálculos de produção relacionados ao fuste das árvores das áreas reflorestadas, pois este demanda uma aferição mais simples e, por isso, de menor custo. 


\title{
Capítulo IV
}

\begin{abstract}
Neste capítulo será feita a conceituação e discussão acerca das cooperativas, modalidade conjunta de trabalho que possibilita a agregação dos agricultores, organizando e convergindo seus esforços para a produção ou para o desenvolvimento de um serviço.

O modelo de cooperativa aqui proposto tem o objetivo de agregar os produtores rurais, fortalecendo-os no cultivo de florestas de eucalipto destinadas ao MDL.
\end{abstract}




\section{As cooperativas}

Se o MDL é o mecanismo de flexibilização que permite a participação formal e voluntária dos países em desenvolvimento no combate às mudanças climáticas (e uma consequente participação do mercado de carbono através da comercialização dos certificados de redução de emissões), a cooperativa é um instrumento potencial de ligação e suporte ao agricultor, no emprego de projetos de reflorestamento para os fins de MDL, possibilitando uma economia de escala.

O simples cultivo de eucalipto para a produção de madeira serrada e a boa condução do projeto com a finalidade de participação no MDL não bastam. É preciso que a cultura seja supervisionada, desde a mensuração da área, passando-se pela escolha da variedade que mais se adeque à região, preparo do solo, espaçamento, plantio, tratos culturais e colheita. Para essa supervisão, a existência e o suporte de uma cooperativa são fundamentais.

A formação de cooperativas florestais - processo que já evolui bem no Canadá, por exemplo - é um meio proposto neste projeto visando o emprego em regionais agrícolas. As cooperativas teriam por objetivo o apoio ao agricultor e 0 seu fortalecimento frente ao mercado mundial de carbono; exerceriam, portanto, o papel de intermediadoras. Tais formações, que devem ser de âmbito regional, podem gerenciar a homogeneização na condução da cultura do eucalipto para todas as propriedades, em todo o seu estágio produtivo até a colheita e na negociação do projeto para este ser aceito como um projeto de MDL.

Uma cooperativa deve ficar encarregada de prestar essa supervisão em conjunto com as casas agrícolas da região, provendo técnicas adequadas ao manejo do eucalipto. Alimentariam, desta forma, o ciclo de produção regional, fazendo escoar a madeira e gerando um mercado local deste produto. 


\subsection{Um breve histórico}

"A economia solidária é uma criação em processo contínuo de trabalhadores em luta contra o capitalismo. Como tal, ela não poderia preceder 0 capitalismo industrial, mas o acompanha como uma sombra em toda sua evolução." O conceito de cooperativismo ou economia solidária, como relata SINGER (2000b.), é relativamente recente. Após a Revolução Industrial, houve uma forte ameaça aos trabalhadores organizados em corporações que desenvolviam atividades manuais. Altamente qualificados e especializados, esses profissionais passavam por um momento crítico com o desenvolvimento e emprego crescente de máquinas que substituíam suas atividades (id.). Além do mais, segundo o mesmo autor, a partir da segunda década do século $X X$, surgiu uma nova doutrina que aceitava o industrialismo, mas não aceitava a sua estrutura capitalista. Desta forma, nasceu o socialismo moderno, cujo rebatimento no plano econômico concreto foi o sindicato e a economia solidária.

Segundo SINGER (2000b.), os resultados históricos de cerca de 2 séculos que vêm sendo postos em prática por trabalhadores e estudados por pesquisadores, podem ser sintetizados da seguinte forma:

1 - Homens e mulheres vitimados pelo capital organizam-se como produtores associados tendo em vista não só ganhar a vida, mas reintegrar-se à divisão social do trabalho em condições de competir com as empresas capitalistas;

2 - Pequenos produtores de mercadorias, do campo e da cidade, associam-se para comprar e vender em conjunto, visando economias de escala, e passam eventualmente a criar empresas de produção socializada, de propriedade deles;

3 - Assalariados associam-se para adquirir, em conjunto, bens e serviços de consumo, visando ganhos de escala e melhor qualidade de vida; 
4 - Pequenos produtores e assalariados associam-se para reunir suas poupanças em fundos rotativos, que Ihes permitem obter empréstimos a juros baixos e, eventualmente, financiar empreendimentos solidários;

5 - Os mesmos criam também associações mútuas de seguros, cooperativas de habitação, etc.

Este histórico vem se repetindo, aperfeiçoando-se e ganhando força. Hoje, há cooperativas espalhadas pelo Brasil e pelo mundo, participando dos mais diversos setores, como será visto adiante.

\subsection{Conformações de uma cooperativa}

Uma empresa cooperativa que desenvolve atividades de compra, produção e/ou venda tem um caráter socialista. É o inverso de uma empresa capitalista, onde o foco é maximizado no lucro, além de estar sob o poder de decisão de poucas pessoas. Na cooperativa, os trabalhadores gerenciam todas as atividades de forma a se criar um vínculo ético entre todos os sócios da cooperativa. A responsabilidade é maior para cada sócio, porém, os benefícios trazidos também são maiores pelo fato de cada sócio ser dono equalitário da atividade e ter influência na tomada de decisões.

A Aliança Cooperativa Internacional $(\mathrm{ACl})$ é uma organização nãogovernamental que congrega organizações cooperativas de todo o mundo. Há membros cooperados de todos os setores e atividades como a agropecuária, crédito, eletrificação, trabalho, habitação, turismo e consumo, entre outras. São mais de 230 organizações espalhadas por cerca de 100 países, contendo mais de 730 milhões de cooperados em todo o mundo. A ACl tem como função facilitar, coordenar e consolidar as organizações cooperativas de todo o mundo. $O$ princípios pregados pela $\mathrm{ACl}$ são os seguintes:

- Adesão voluntária e aberta; 
- Gestão democrática por parte dos sócios;

- Participação econômica por parte dos sócios;

- Autonomia e independência;

- Educação, formação e informação;

- Cooperação entre cooperativas;

- Interesse pela comunidade.

Pode-se citar empresas cooperativas brasileiras bem sucedidas, como a fábrica Parayba, que tem unidades de produção em Pernambuco e São José dos Campos e a fábrica Wallig, que produz fogões e está sediada no Rio Grande do Sul (SINGER, 1999). A maior usina de cana-de-açúcar da América Latina, no sul de Pernambuco, é uma cooperativa que está em funcionamento dentro destes moldes, desde 1996 (SINGER, 2001).

A atuação isolada de uma cooperativa numa região onde dominam os mercados capitalistas é um fator que debilita sua ação. Nessas condições, ela tem pouco ou nenhum acesso ao crédito, rede de comercialização ou assessoria técnica.

Existem também exemplos de redes de cooperativas bem sucedidas. Complexo Cooperativo de Mondragón talvez seja o exemplo de cooperativa mais bem sucedido do mundo. Com mais de 100 cooperativas de produção, conta com um banco (Caja Laboral Popular), uma das maiores redes de supermercados da Espanha, além de uma universidade e diversas cooperativas de investigação tecnológica.

Na formação de uma cooperativa, seus sócios devem interagir, fazer cursos sobre cooperativismo e se estruturar administrativa e politicamente. $O$ aprendizado e a prática da autogestão vêm com o tempo, com a diferença (em relação à uma empresa capitalista) que esse aprendizado estende-se a todos os associados de uma cooperativa. 
O nascimento de uma cooperativa requer geralmente auxílio ou impulso externo, vindo de outras empresas cooperativas, incubadoras (órgãos especializados em formar e amparar tais empreendimentos), sindicatos, entidades religiosas, organizações não governamentais.

\subsection{Grau das cooperativas}

Há cooperativas nos mais diversos setores e atividades. As cooperativas simples, de grandeza regional, são consideradas de $1^{\circ}$ grau. Quando estas cooperativas se reúnem para realizar operações comuns de compra, venda, produção ou pesquisas tecnológicas, são caracterizadas como cooperativas de $2^{\circ}$ grau. Estas cooperativas têm abrangência territorial maior, ocupando regiões ou estados. Um exemplo de cooperativa de $2^{\circ}$ grau são as atacadistas, que compram e distribuem mercadorias para cooperativas varejistas. As cooperativas de $3^{\circ} \mathrm{grau}$ são aquelas que reúnem as cooperativas de $2^{\circ}$ grau e têm uma abrangência maior, podendo ser até de porte nacional. As cooperativas de $4^{\circ}$ grau são aquelas que reúnem as cooperativas de $3^{\circ}$ grau e têm abrangência maior ainda, podendo abarcar um continente ou o mundo inteiro.

As cooperativas de $2^{\circ}, 3^{\circ}$ e $4^{\circ}$ grau existem, pois objetiva-se 0 aproveitamento de ganhos de escala. Isto é, muitas vezes uma cooperativa não tem condições de compra e emprego de equipamentos mais sofisticados ou instalações que exijam dinheiro ou infra-estrutura avançada. Neste ponto, as cooperativas associam-se trocando serviços e entrelaçando suas atividades, onde o seu sequenciamento só é possível na existência de cooperativas que se enquadrem dentro destes moldes.

No presente estudo, propõe-se a formação de cooperativas de $1^{\circ} \mathrm{grau}$, ou até de $2^{\circ} \mathrm{grau}$, considerando o crescimento desta a atividade, ou o trabalho conjunto de produtores florestais e serrarias, para processamento da madeira, por exemplo. 
As cooperativas podem ainda ser estratificadas quanto às dimensões, da seguinte maneira:

- Cooperativas de produção industrial e de serviços, dotadas de capital abundante, que empregam a melhor tecnologia e se mostram competitivas no mercado mundial ou em mercados nacionais;

- Cooperativas dotadas de capital modesto, que empregam tecnologias herdadas de empresas antecessoras e enfrentam grandes dificuldades para se manter em alguns mercados;

- Grande número de pequenas associações de trabalhadores marginalizados ou de pessoas estigmatizadas (ex-detentos, deficientes físicos, moradores de rua) que procuram desenvolver alguma atividade produtiva, mas que sobrevivem emgrnade parte de doações e do trabalho voluntário de apoiadores externos.

Deve-se adicionar ainda as cooperativas de trabalho, que não têm outro capital senão a capacidade de trabalho. Estas cooperativas vendem serviços. Dentro da economia solidária, enquadram-se ainda os clubes de troca, formados por pequenos produtores de mercadorias, que constroem para si um mercado protegido ao emitir uma moeda própria, que viabiliza o intercâmbio entre os participantes. Há outras cooperativas de consumidores, como as de crédito, habitação, saúde e escolares.

\subsection{As incubadoras universitárias}

SINGER et al. (2000) relata que as Incubadoras Tecnológicas de Cooperativas Populares (ITCP) nasceram em meados da década de 90. Pertencem às universidades e são, acima de tudo, educacionais. Visam, portanto, auxílio à população que ainda não se inseriu no mercado. Tiveram origem na 
Coordenação dos Programas de Pós-Graduação de Engenharia da Universidade Federal do Rio de Janeiro (COPPE/ UFRJ).

As ITCP's dão apoio administrativo, jurídico, legal e ideológico à população mais pobre em cooperativas de produção ou de trabalho. Um dos seus objetivos é o de assessorar o trabalho de cooperativas populares. Há ITCP's em 14 universidades brasileiras. Suas reuniões ocorrem trimestralmente para troca de experiência e organização de atividades conjuntas. Estas incubadoras têm uma maior aceitação se comparadas aos órgãos do governo. As seguintes características configuram-se como vantagens das ITCP's,:

- Trata-se de uma rede de universidades, havendo condições para se proporcionar uma continuidade nos trabalhos devido ao ingresso anual e contínuo de novos alunos;

- Apresentam uma maior imparcialidade - uma universidade tem o papel e o objetivo sobretudo educacional e de forma gradativa;

- A diversidade de formações e opiniões contribui para a formação de idéias de ampla gama e com fundação multidisciplinar;

- Há uma reciclagem de idéias devido ao grande fluxo de alunos, profissionais e interessados envolvidos no projeto.

São princípios das ITCP's:

- Reafirmar os princípios da ACl;

- Conceber a universidade como uma instituição a ser respeitada como local de produção e socialização, autônoma sob o ponto de vista crítico e produtivo;

- Disseminar e desenvolver os conceitos sobre cooperativas, desenvolvendo assim o conceito sobre economia solidária;

- Estimular intercâmbio de conhecimento entre as incubadoras e destas com o meio universitário, outras redes e a sociedade; 
- Estimular a criação de ITCP, promovendo e discutindo a sua inserção na rede;

- Organizar-se com outras redes que apresentem princípios convergentes;

- Trabalhar na constituição, consolidação e integração das cooperativas populares.

O destaque dado às ITCP's neste trabalho serve como indicador de que existe um suporte teórico-prático dentro do território nacional para acolher as cooperativas que se encontram no início de seu desenvolvimento ou gerenciamento. Portanto, estas incubadoras podem prestar auxílio para que seja encaminhado o desenvolvimento de uma cooperativa no setor florestal.

\subsection{Cooperativas Florestais}

De acordo com SINGER (1999), "as cooperativas de produção agropecuária trabalham as terras de todas as famílias cooperadas em conjunto, fazem um plano de produção, produzem, transformam, procuram desenvolver agro-indústrias processadoras dos seus produtos, vendem e depois têm critérios entre eles para repartir tudo aquilo que foi apurado".

A cooperativa deve decidir como será feita a repartição da renda entre seus sócios. Caso haja uma sobra de dinheiro no final do ano, a cooperativa faz a sua divisão geralmente em três partes:

- Atividades educativas dos próprios sócios ou outros trabalhadores envolvidos com a cooperativa;

- Repartição entre os trabalhadores, em dinheiro ou, mais frequentemente, em créditos que dão juros, mas só podem ser sacados quando os associados deixarem as cooperativas; 
- Um fundo indivisível, que pertence ao grupo cooperado e que passa de geração para geração, à medida que os mais velhos se retiram e dão lugar aos mais novos.

De acordo com RODRIGUES (1999), a proposta de reflorestamento em terras não agricultáveis e com o uso de cooperativas já existe. Em novembro de 1998, em Madrid, a SOCODEVI (Societé de Coopération pour le Dévéloppement International), uma entidade canadense que presta apoio a países em desenvolvimento, sugeriu ao cooperativismo brasileiro que fossem aproveitadas as terras não agricultáveis para implantação de projetos florestais guiados por cooperativas.

Em Quebec, no Canadá, há 45 cooperativas atuantes no setor florestal. Cerca de 5.900 sócios reúnem-se para o arrendamento de terras, produzindo $800.000 \mathrm{~m}^{3}$ de madeira serrada por ano a um valor de US\$279 milhões. Possuem 13 serrarias e plantam aproximadamente 110 milhões de mudas. A força do setor florestal de Quebec é tão expressiva, que gera cerca de 150 mil empregos diretos e indiretos, com faturamento anual total de US\$13 bilhões (id.).

Tal exemplo é um bom indicativo de que o Brasil pode desenvolver projetos semelhantes de reflorestamento e tirar proveito não só do produto final (madeira serrada), como da comercialização de créditos de carbono, através da inserção do projeto no MDL.

\subsection{Objetivos da cooperativa florestal}

Através da montagem de uma cooperativa florestal, são objetivos principais a agregação de pequenos, médios e grandes produtores, o trabalho em uma economia de escala maior e a obtenção de um produto homogêneo, não só em sua qualidade como em sua assiduidade no mercado. Ao se juntarem, os produtores disponibilizam uma parcela de suas terras para o cultivo de eucalipto. 
Como é proposto no presente projeto (no capítulo V) quando os proprietários ficam juntos, na mesma regional agrícola, isso possibilita uma maior homogeneização, tanto na conduta, como na obtenção do produto final.

Propõe-se no presente estudo que haja uma participação dos associados através de cotas de terras, a serem definidas pelos mesmos. Um projeto de dimensão regional como este pode receber o auxílio de empresas florestais da região, como a Eucatex e a Duratex, neste caso específico; apoio financeiro, tecnológico e logístico de empresas que já têm vasta experiência no ramo florestal.

São objetivos mais específicos, a educação, conscientização e informação dos associados a respeito das mudanças climáticas e sua inserção no mercado do carbono através da participação do $\mathrm{MDL}$, com o projeto de reflorestamento. Além disso, a produção de madeira para fins de serraria, podendo ser empregada em movelaria ou construção civil, e a comercialização dos certificados de MDL são outros objetivos específicos na constituição de uma cooperativa florestal.

\subsection{Problemas enfrentados}

Muitas dificuldades podem ser destacadas ao se estruturar uma cooperativa. Com uma cooperativa florestal não é diferente. O primeiro problema seria agregar os proprietários locais e conscientizá-los de que é possível dispor de uma pequena parcela de suas terras para que aumentem sua renda com um projeto de reflorestamento. É preciso divulgação do projeto e, mais que isso, que ele se adeque aos moldes culturais e sociais da região. Portanto, o processo de formação de uma cooperativa e o espírito coletivo de seus cooperados é um processo educativo, de crescimento lento e gradual.

O gerenciamento das atividades, a junção das parcelas para cultivo do eucalipto, a divisão do trabalho, os cálculos mais detalhados dos cusuos e receitas 
do projeto, entre outros pontos, exigem pessoal treinado, demandando uma disponibilidade de capital para estes serviços.

A implementação do projeto necessita muitas vezes da colaboração e participação do setor público ou privado, na forma de divulgação, donativos ou empréstimo de técnicos especializados nas áreas de silvicultura, administração e economia, entre outras: é necessário que os associados tenham esses conhecimentos técnicos, indispensáveis para a boa condução de um projeto florestal.

O tempo de aprendizado e crescimento, até que a cooperativa atinja uma desenvoltura mínima, é um problema a ser enfrentado pelos seus associados. A boa atuação de uma empresa cooperativa é dependente de uma série de fatores, como a união do grupo, o acesso fácil a técnicos para o acompanhamento e até disponibilidade financeira para o desenvolvimento do projeto.

O grau de instrução dos proprietários das Unidades de Produção Agropecuária (UPA) é outro ponto dificultante, pois mais da metade destes proprietários possui um grau de escolaridade baixo. Isso não exclui a participação destes em um projeto que envolva reflorestamento, mas a baixa escolaridade é uma barreira para o entendimento e implementação de um programa de reflorestamento que envolva questões políticas acerca do Protocolo de Quioto.

Mais uma barreira que a cooperativa florestal pode enfrentar é quanto aos custos de transação do projeto de reflorestamento. Segundo FUJIHARA ${ }^{40}$ (2002), o processo de auditoria florestal, que consiste na verificação e certificação do projeto, tem um custo estimado por volta de US\$30.000. A elaboração da Linha de Base demanda outros US\$30.000 para o projeto. Para uma cooperativa florestal que acaba de se formar, este pode ser considerado um fator essencial, de altos custos de transação, podendo inviabilizar o p[rojeto de acordo com as suas dimensões. 
Antes de tentar sua aceitação no $\mathrm{MDL}$, seria um ponto positivo obter-se certificação florestal de alguma entidade certificadora e reconhecida internacionalmente. Através desta certificação, também chamada de "selo verde", prova-se, através de organizações especializadas, como a Forest Stewardship Council (FSC), que a floresta em questão é: ambientalmente adequada (ao promover o desenvolvimento sustentável); socialmente benéfica (ao empregar mão-de-obra local e trazer outros benefícios à população regional) e economicamente viável (ao garantir renda aos cooperados). A existência do selo verde não é obrigatória para o ingresso de projetos como este no MDL. É, no entanto, um indicador de que as florestas estão sendo devidamente manejadas mediante um órgão de reconhecimento internacional, apresentando desta forma, uma preocupação ambiental; portanto, uma busca por parte do projeto de se enquadrar no moldes sustentáveis e ambientais propostos pelo Protocolo. Para o MDL, apresentar esses selos conta créditos no momento da aprovação. $O$ problema é mais uma vez o custo. Estar-se-á agregando valor ao produto para que este fique mais próximo da aceitação na participação do $\mathrm{MDL}^{41}$, demandando desta forma, um gasto financeiro adicional do projeto.

A credibilidade que uma cooperativa florestal oferece, do ponto de vista do comprador dos créditos de carbono, pode ser uma desvantagem. Não há garantias de que o grupo empenhado em desenvolver estas atividades permença consistente até o final do ciclo, podendo causar, eventualmente, prejuízos aos demais associados. Não há, teoricamente, um único responsável pelas atividades e pelo andamento da produção. Se houver uma quebra na produção, de alguma forma, e o grupo for acionado judicialmente, a indicação de um cooperado que responda pelas questões referentes ao projeto deve ser feita de modo a assegurar a integridade do grupo.

\footnotetext{
${ }^{40}$ FUJIHARA, M.A. Consultor em MDL. Entrevista concedida em São Paulo, em 24/02/2002.
} 


\subsection{Vantagens de uma cooperativa florestal}

Os benefícios trazidos por uma cooperativa podem ser inúmeros. Relatos feitos a SINGER et al.(2000), indicam que, além do ganho econômico, as cooperativas proporcionam aos seus associados uma melhora na auto-estima, na identificação com o trabalho e com o grupo produtivo, companheirismo, noção crescente de autonomia e de direitos dos cidadãos.

Através da cooperativa florestal, pode-se proporcionar o trabalho conjunto de produtores com propriedades agrícolas em uma mesma região. Isto traz uma integração maior por parte destes produtores, com o ganho de escala da área a ser trabalhada, além de um aquecimento local da economia. A junção de mão-deobra das propriedades e da troca técnica que pode ocorrer estão entre outras vantagens oferecidas por cooperativas florestais.

Este pensamento pode ser desenvolvido do ponto de vista do produtor: uma cooperativa florestal traz uma credibilidade maior se comparada a um projeto florestal particular isolado, desde que este último não seja gerenciado por uma empresa, como se observa, em alguns exemplos. Esta cooperativa pode envolver a comunidade local, obter apoio das empresas florestais da região, além do apoio do governo. Tudo isso garante uma projeção do projeto, para que este possa ser discutido e avaliado no meio empresarial, acadêmico e junto à sociedade.

${ }^{41}$ FUJIHARA, M.A. Dr. Em Economia agrícola. Palestra proferida na Faculdade Getúlio Vargas, em São Paulo, em 18/03/2002. 


\section{Capítulo V}

Os capítulos I, II ,III e IV foram descritivos e conceituais. No capítulo V, caberá a apresentação dos dados referentes aos cálculos do projeto. Será descrita a metodologia aplicada no projeto de reflorestamento além da discussão desta metodologia e dos cálculos a respeito da implantação do projeto e de sua viabilidade como candidato à participação dentro do MDL.

Deve-se atentar que o desenvolvimento deste projeto visa a implantação em áreas já degradadas, sem que haja competição com áreas destinadas à pecuária, culturas agrícolas ou que contenham florestas nativas. Trata-se, inclusive, de um projeto que visa a redução da pressão sobre as florestas nativas e o aumento no uso de madeira proveniente de reflorestamento de espécies de rápido crescimento.

Como o Protocolo de Quioto ainda não foi ratificado e a metodologia e regulamentação para projetos florestais ainda não foi estabelecida, serão discutidos de uma forma geral os sucessos e os insucessos de um projeto florestal, como o que se segue. 


\section{Metodologia}

Para as discussões de viabilidade de um projeto florestal para o MDL, será proposto um breve exercício, servindo como exemplo a regional agrícola de Botucatu, localizada no estado de São Paulo.

Primeiramente, será descrita a região escolhida para a implantação do projeto. Será caracterizada a área dentro desta regional e, logo após, as espécies que melhor se adaptam ao local. Tudo isso tendo como base um zoneamento ecológico esquemático para reflorestamento, desenvolvido em 1978, para as espécies de Pinus e Eucalyptus, dentro do território nacional.

Com base na caracterização da área disponível e nos custos de implantação, manutenção e colheita da cultura - além dos custos de transação e dovalor pago pela tonaleda de carbono - será feita a discussão acerca da viabilidade de um projeto de reflorestamento para os fins de MDL.

\subsection{Regionais agrícolas}

A adoção de regionais agrícolas apresenta algumas vantagens: possibilidade de um maior controle entre os cooperados, quanto à qualidade da condução da cultura e maior padronização do produto final; possibilidade de estabelecer bases mais sólidas entre os associados, devido às distâncias que os unem à cooperativa.

O espaço físico que servirá de laboratório experimental para o presente exercício será a regional agrícola (ou micro-região) de Botucatu, localizada no interior do estado de São Paulo.

O estado de São Paulo é formado por 41 regionais agrícolas e Botucatu é uma delas. A regional de Botucatu é constituída por 11 municípios menores: 
Areiópolis, Pratânia, São Manuel, Botucatu, Itatinga, Pardinho, Bofete, Anhembi, Conchas, Pereiras e Laranjal Paulista. A regional de Botucatu faz divisa com as regionais de Piracicaba, Avaré, Jaú e Itapetininga. De acordo com a CATI (1996), estas outras quatro regionais agrícolas somam mais 120.000 hectares de eucalipto plantado, o que demonstra uma boa adaptação da cultura em toda a região.

O estado de São Paulo e a regional agrícola de Botucatu foram escolhidos pelos seguintes motivos: o estado de São Paulo é o segundo produtor brasileiro de eucalipto e Botucatu representa $2 \%$ de todo esse gênero plantado no território nacional (REVISTA DA MADEIRA, 2001). Além disso, indústrias florestais, como a Eucatex e Duratex, possuem filiais na região de Botucatu. Portanto, é clara na região a vocação no emprego de espécies de eucalipto para o cultivo em escala. As figuras 5.1. e 5.2. mostram, respectivamente, o estado de São Paulo dividido em regionais agrícolas e a regional agrícola de Botucatu dividida em municípios.

Figura 5.1. - O estado de São Paulo e suas regionais agrícolas.

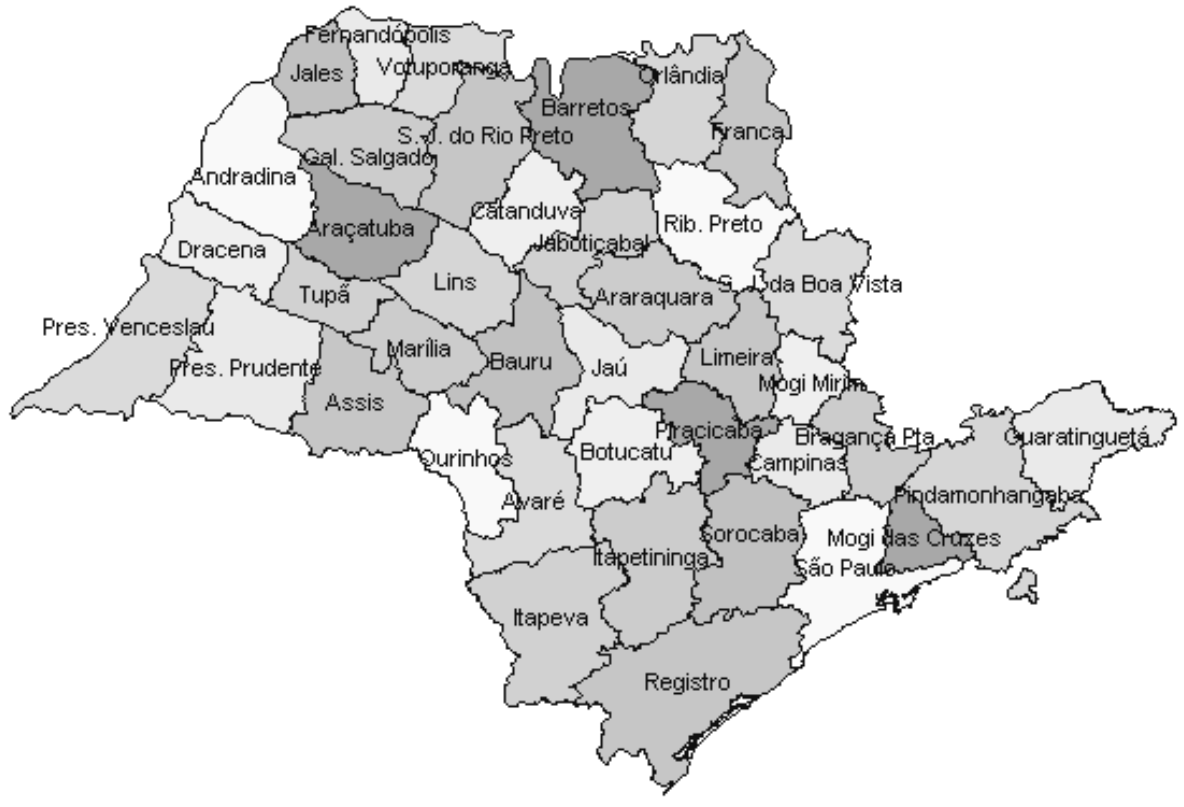

Fonte: CATI, 2001. 
Figura 5.2. - Mapa da regional agrícola de Botucatu.

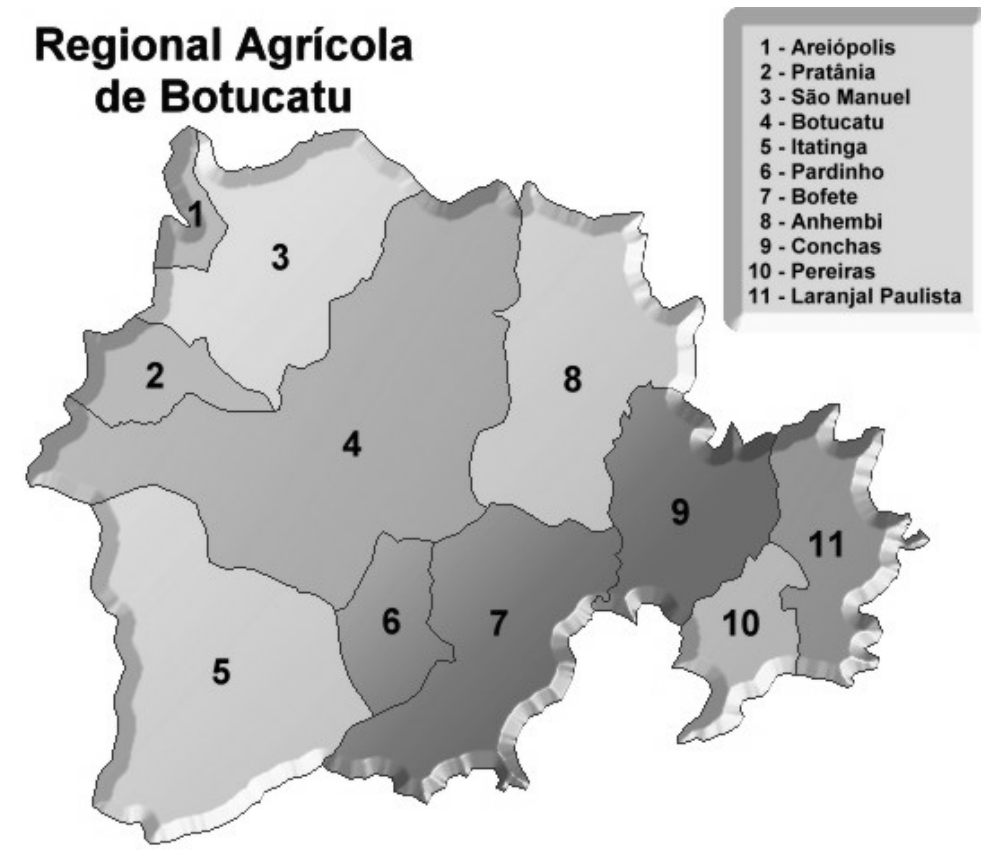

Fonte: CATI, 2001

Uma regional agrícola é formada por parcelas de tamanhos e finalidades variadas, denominadas Unidades de Produção Agropecuária (UPA).

O número total de UPA's dentro da regional agrícola de Botucatu é de 6.120 unidades. A tabela 5.1. mostra o grau de instrução dos proprietários de UPA's na regional de Botucatu.

Tabela 5.1. - Grau de instrução dos proprietários de Unidades de Produção Agropecuária (UPA) da regional agrícola de Botucatu.

\begin{tabular}{|l|c|c|}
\hline \multicolumn{1}{|c|}{ Grau de instrução } & Nº $^{\circ}$ de UPA's & Percentual \\
\hline Proprietário sem instrução ou com instrução incompleta & 1750 & 28.59 \\
\hline Proprietário com antigo primário completo & 1621 & 26.49 \\
\hline Proprietário com primeiro grau (ou antigo ginasial) completo & 633 & 10.34 \\
\hline Proprietário com segundo grau (ou antigo colegial) completo & 771 & 12.60 \\
\hline Proprietário com curso superior completo & 1345 & 21.98 \\
\hline
\end{tabular}

Fonte: CATI 1995/1996. 
O grau de instrução é um fator muito importante e pode ser decisivo na adoção de um projeto para os fins de MDL, quando este projeto é comandado por vários trabalhadores de grau de instrução também variado. De acordo com a tabela acima, mais da metade dos proprietários têm até o primário completo. Apenas $34 \%$ dos proprietários das UPA's têm o segundo ou terceiro grau completos. Isto, porém, não isenta o segundo estrato de não ter conhecimento da questão das mudanças climáticas. A probalidade é maior de que o primeiro estrato não tenha conhecimento destas questões e que o segundo estrato tenha mais acesso à esses tipos de informação. A questão do grau de instrução e o acesso a informações quando da estruturação de um projeto de reflorestamento para os fins de MDL, são fatores que pesam menos, caso haja um forte suporte de cooperativas aos seus associados, com o objetivo de dar todas as informações cabíveis e necessárias relativas ao projeto.

\section{2. Área destinada ao projeto}

A área destinada ao projeto de reflorestamento deve ocupar espaço não conflitivo com as atividades já em andamento. Portanto, é candidata ao projeto aquela área considerada inaproveitável, dentro da classificação do projeto LUPA (descrito a seguir). $\mathrm{O}$ uso de áreas inaproveitáveis para emprego do reflorestamento para fins do MDL é optativo. Sugere-se esta área por não ser conflitiva com atividades agrícolas ou pecuárias que já estejam sendo desenvolvidas na propriedade. Pode o agricultor, porém, optar por implantar ou aumentar sua área de reflorestamento aproveitando parte da área destinada à pecuária ou culturas agrícolas, por exemplo.

Vale lembrar que, para projetos de MDL, podem ser utilizadas para florestamento e reflorestamento somente áreas que, a partir de 31 de dezembro de 1989 , foram utilizadas como pastagens ou abandonadas, sem que contivessem florestas. 
Para o cálculo de área a ser empregada no projeto de reflorestamento, serão utilizados dados coletados do Instituto Brasileiro de Geografia e Estatística (IBGE) e da CATI ${ }^{42}$, todos eles referentes aos anos de 1995/1996.

\subsection{1. Área de proteção ambiental}

Localiza-se em parte da regional agrícola de Botucatu, um trecho da Área de Proteção Ambiental (APA) de Corumbataí-Botucatu-Tejupá. A área total desta APA é de 649.828 ha, pertencendo a Botucatu, um montante de 218.828 hectares. A criação desta APA deu-se em 8 de junho de 1983, através do decreto estadual $n^{\circ} 20.960$.

De acordo com a conceituação da Secretaria de Estado e Meio Ambiente de São Paulo, as APA's são "extensas áreas que possuem ecossistemas de importância, englobando um ou mais atributos ambientais". Em outras palavras, são regiões de interesse de proteção ambiental, com o objetivo de assegurar a conservação e a recuperação de recursos naturais.

Ainda de acordo com a mesma fonte, estas áreas necessitam de um ordenamento territorial para o uso dos recursos naturais, de modo que haja participação da sociedade, resultando em uma melhora na qualidade de vida das comunidades locais.

É possível que dentro das áreas inaproveitáveis (escolhidas para o emprego do presente projeto), haja trechos de APA. No entanto, estas áreas de proteção podem estar espalhadas inclusive por pastagens ou locais onde haja culturas agrícolas. Deve-se atentar no momento de escolha das áreas para reflorestamento e, que estas tragam os benefícios sociais locais acima citados.

42 A CATI, Coordenadoria de Assistência Técnica Integral, é um órgão pertencente à Secretaria de Agricultura do Estado de São Paulo, que, por sua vez, é um órgão pertencente ao governo do 


\subsubsection{Projeto LUPA}

Foi desenvolvido pela CATI um censo agropecuário do estado de São Paulo, denominado LUPA: Levantamento das Unidades de Produção Agropecuária. Neste censo, há o levantamento do destinamento das terras e a quantificação de todas as suas modalidades de uso. Dessa maneira, sabe-se, dentro de cada município do estado de São Paulo, quanto de terra está sendo ocupada por atividades de pecuária, culturas anuais, perenes, semi-perenes, áreas destinadas às matas naturais, áreas reflorestadas, em descanso e áreas sem aproveitamento.

Serão contabilizadas para o projeto de reflorestamento apenas as terras que se enquadrarem dentro do conceito de áreas inaproveitáveis. Isto significa dizer que a implementação desse projeto não é conflitiva com áreas já ocupadas (ou que poderiam vir a ser) com atividades agrícolas (pecuária e agricultura) ou com florestas naturais lá existentes.

Composta por 11 municípios, a regional agrícola de Botucatu perfaz uma área total de 534.593 hectares, sendo 63.802,9 hectares de reflorestamento (dos quais $60.421,3$ hectares são de eucalipto), 272.753,7 hectares de pastagens, 9.585,3 hectares de área inaproveitável e o restante (128.029,8 hectares) referente às áreas com culturas (perene, semi-perene, anual), áreas de vegetação natural, áreas complementares e áreas inaproveitadas (CATI, 1996).

A título de ilustração, a tabela 5.2. demonstra a divisão do solo agropecuário brasileiro. Vale ressaltar que estes números são baseados na área total ocupada com atividades agropecuárias e não na área total do território nacional. 
Tabela 5.2. - Utilização do solo agropecuário Brasileiro de acordo com o censo agropecuário do IBGE -1995/1996.

\begin{tabular}{|c|c|}
\hline Classificação & Área ( \%) \\
\hline Terras inaproveitáveis & 4.8 \\
\hline Plantações florestais & 2.3 \\
\hline Pastagens plantadas & 29.7 \\
\hline Pastagens naturais & 25.9 \\
\hline Lavoura & 15.8 \\
\hline Florestas naturais & 15.9 \\
\hline Área produtiva não aproveitada & 3.3 \\
\hline Área de descanso & 2.3 \\
\hline TOTAL & $\mathbf{1 0 0}$ \\
\hline
\end{tabular}

Fonte: Revista Gleba, apud MORA et al., 2000.

A tabela 5.3. indica a distribuição de terras pelos municípios e o destino de área para cada atividade.

Tabela 5.3. - Disposição e aproveitamento de áreas da regional agrícola de Botucatu (1995/1996).

\begin{tabular}{|c|c|c|c|c|c|c|}
\hline Município & Área total* & $\begin{array}{l}\text { Refloresta- } \\
\text { mento* }\end{array}$ & Eucalipto* & $\begin{array}{c}\text { Área } \\
\text { inaproveitada* }\end{array}$ & $\begin{array}{c}\text { Área } \\
\text { inaproveitável* }\end{array}$ & $\begin{array}{c}\text { Área com } \\
\text { pastagem* }\end{array}$ \\
\hline Areiópolis & 9122,5 & 34,7 & 34,7 & 43,6 & 69,8 & 333,4 \\
\hline Pratânia & 22826,3 & 2239,3 & 1946 & 0 & 334,9 & 10658,8 \\
\hline São Manuel & 52556,3 & 1959,8 & 1842,9 & 1 & 1500,6 & 14901,5 \\
\hline Botucatu & 136663,5 & 19241,2 & 18952,1 & 1878,3 & 1897,2 & 67679,8 \\
\hline Itatinga & 84529,2 & 24834,1 & 23009,1 & 212,9 & 2572,4 & 42266 \\
\hline Pardinho & 19027,4 & 763 & 758,8 & 93,1 & 164,3 & 13702,8 \\
\hline Bofete & 60126,8 & 10146,3 & 9169,9 & 483,4 & 2054,3 & 10146,3 \\
\hline Anhembi & 59975,9 & 3520,3 & 3649,8 & 131,4 & 237,6 & 42036,8 \\
\hline Conchas & 38532,3 & 628,4 & 624,2 & 2,7 & 587,7 & 32583 \\
\hline Pereiras & 20306,8 & 127,8 & 127,8 & 33,6 & 80,5 & 17436,8 \\
\hline ranjal Paulista & 30926 & 308 & 306 & 255,7 & 86 & 21008,5 \\
\hline Total & 534.593 & $63.802,9$ & $60.421,3$ & $3.135,7$ & $9.585,3$ & $272.753,7$ \\
\hline
\end{tabular}

Fonte: Projeto LUPA - CATI (1995/96)

* Todas as áreas são expressas em hectares

$\mathrm{Na}$ tabela 5.3. não foram inclusos os dados referentes à cultura perene, semi-perene, anual e área com vegetação natural. Por este motivo, a somatória total das atividades relacionadas não correspondem aos 100\% dos 534.593 ha. 
A área de reflorestamento na regional de Botucatu corresponde a praticamente $12 \%$ de ocupação da área agrícola. A área destinada à pecuária, na regional de Botucatu, corresponde a $51 \%$ da regional. Nada impede que a área destinada à atividade pecuária possa ser utilizada para o emprego de atividades florestais, assim como aquelas destinadas às culturas agrícolas.

Como já foi ressaltado anteriormente, o presente projeto objetiva a ocupação de áreas que não sejam conflitivas com as que já estejam em uso. Enquadram-se nessa categoria as áreas classificadas como inaproveitáveis, que correspondem a $9.585,3$ hectares, sendo quase $2 \%$ da área da regional agrícola de Botucatu. Essa é uma área potencial para a implantação deste projeto. As terras destinadas a culturas e pastagens também poderiam entrar na contablilidade do projeto de reflorestamento.

\subsection{Zoneamento}

O zoneamento ecológico desenvolvido por Golfari é considerado por especialistas da área florestal ${ }^{43}$ como um estudo minucioso e profundo, feito a respeito do emprego dos gêneros Pinus e Eucalyptus para reflorestamento no Brasil. A figura 5.3. mostra o zoneamento ecológico para o estado de São Paulo com a regional agrícola de Botucatu circundada. Como pode-se observar, a regional faz intersecção com três zonas, tendo cada uma um grupo de espécies de Eucalyptus mais aptos ao cultivo. A tabela 5.4. demonstra estas espécies para cada região.

${ }^{43}$ GONÇALVES, J.L.M. Prof. Titular do Departamento de Ciências Florestais - ESALQ/USP; NAHUZ, M.A.R. Divisão de Produtos Florestais - IPT/USP. 
Figura 5.3. - Zoneamento Ecológico Esquemático para Reflorestamento no Brasil - Estado de São Paulo.

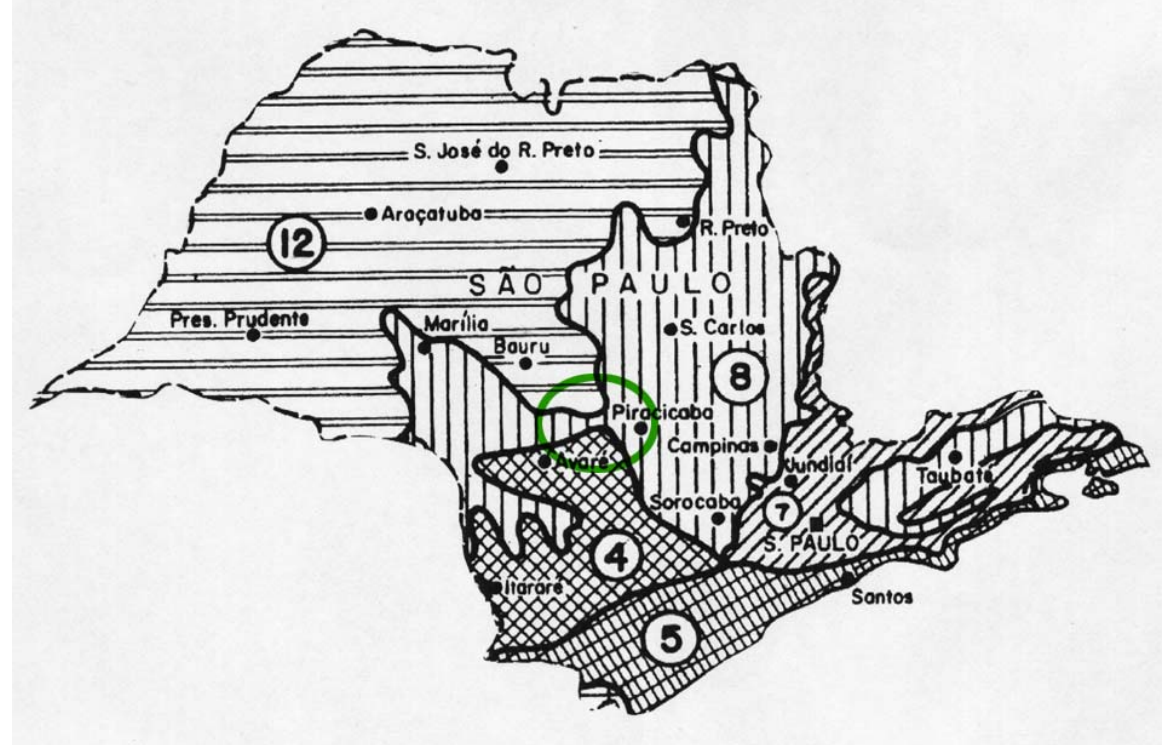

Fonte:GOLFARI, 1978

No Zoneamento Ecológico Esquemático para Reflorestamento no Brasil, proposto por Golfari (1978), o território nacional é dividido em 26 regiões. Cada uma delas é caracterizada pela semelhança de altitude, tipo de clima, vegetação, temperatura média anual, precipitação média anual, presença ou não de deficiência hídrica e ocorrência ou não de geadas. Para cada região, há um grupo de espécies de eucalipto e pinus que mais se adaptam às condições locais. São indicadas para o zoneamento, 25 espécies de eucalipto. Como o estudo tem mais de 20 anos (o que não exclui sua qualidade e peso científico), algumas espécies citadas no mesmo já não são cultivadas em escala comercial.

Com posse dos dados deste zoneamento ecológico e através da tabela 5.2., pode-se observar a possibilidade do emprego deste projeto para outras regionais e outros estados brasileiros, utilizando-se áreas inaproveitáveis.

A região agrícola de Botucatu faz intersecção com as regiões do zoneamento proposto por Golfari, de número 4, 8 e 12. Isto significa que ela é propícia para um bom desenvolvimento das espécies E. dunnii, E. grandis, E. 
saligna, E. pilularis, E. microcoris, E. pellita, E. maculata, E. cloeziana, E. urophylla, E. tereticornis e E. camaldulensis. As três regiões totalizam 11 espécies diferentes de eucalipto que são aptas ao cultivo. A tabela 5.4., a seguir, indica as espécies de eucalipto que melhor se adaptam à região. Das 11 espécies, foram selecionadas 3 de maior importância não só quanto à extensão de cultivo no Brasil (as três espécies juntas correspondem a $81 \%$ de todo eucalipto plantado em território nacional), como também ao fato de seu cultivo servir para fins de madeira serrada. As espécies descartadas não apresentavam boas características para produção de madeira serrada ou já não eram variedades utilizadas em escala comercial. Outra razão pela seleção de apenas três espécies é que a operação com um número reduzido de espécies vegetais torna-se mais simples, dada a variação de produtividade e a finalidade entre as espécies.

Tabela 5.4. - Relação das espécies de eucalipto que mais se adaptam ao cultivo nas regiões pertencentes à regional de Botucatu.

\begin{tabular}{|c|c|}
\hline Região & Espécies para reflorestamento \\
\hline 4 & E. dunnii; E. grandis; E. saligna \\
\hline 8 & $\begin{array}{c}\text { E. dunnii; E. grandis; E. saligna; } \\
\text { E. maculata; E. cloeziana }\end{array}$ \\
\hline 12 & $\begin{array}{c}\text { E. urophylla; E. Tereticornis; } \\
\text { E. camaldulensis }\end{array}$ \\
\hline
\end{tabular}

Fonte: Golfari, 1978.

A tabela 5.5. especifica as características de localização, altitude, vegetação, clima, temperatura e precipitação das regiões que fazem intersecção com a regional agrícola de Botucatu. 
Tabela 5.5. - Classificação das regiões localizadas na regional agrícola de Botucatu de acordo com as condições bioclimáticas propostas por Golfari.

\begin{tabular}{|c|c|c|c|}
\hline Característica/Região & Região 4 & Região 8 & Região 12 \\
\hline Localização & $\begin{array}{c}\text { Planalto centro-leste do } \\
\text { Paraná e sudoeste de } \\
\text { São Paulo }\end{array}$ & $\begin{array}{c}\text { Planaltos do centro e } \\
\text { leste de São Paulo, sul } \\
\text { de Minas Gerais, } \\
\text { sudoeste do Espírito } \\
\text { Santo e vale superior e } \\
\text { médio do rio Paraíba, } \\
\text { SP. }\end{array}$ & $\begin{array}{l}\text { Oeste de São Paulo, } \\
\text { norte do Paraná e sul } \\
\text { do Mato-Grosso }\end{array}$ \\
\hline Altitude & $600-1.100$ & $600-1.100$ & $250-500$ \\
\hline Tipo de vegetação & $\begin{array}{l}\text { Floresta ombrófila* e } \\
\text { campos submontanos }\end{array}$ & $\begin{array}{c}\text { Floresta perenifólia } \\
\text { estacional submontana }\end{array}$ & $\begin{array}{c}\text { Floresta perenifólia } \\
\text { estacional e cerrado de } \\
\text { baixa altitude }\end{array}$ \\
\hline Tipo de clima & $\begin{array}{l}\text { Submontano, ou } \\
\text { temperado, úmido }\end{array}$ & $\begin{array}{c}\text { Subtropical moderado, } \\
\text { úmido }\end{array}$ & $\begin{array}{l}\text { Subtropical ou tropical } \\
\text { sub-úmido, úmido }\end{array}$ \\
\hline $\begin{array}{c}\text { Temp. média anual } \\
\left(\mathrm{em} \mathrm{C}^{\circ}\right)\end{array}$ & $16-19$ & $18-22$ & $21-24$ \\
\hline Geadas & Pouco frequentes & Raras & Raras \\
\hline $\begin{array}{c}\text { Precipitações médias } \\
\text { anuais }\end{array}$ & $1.100-1.400$ & $1.200-1.700$ & $1.100-1.500$ \\
\hline $\begin{array}{c}\text { Regime de } \\
\text { precipitações }\end{array}$ & $\begin{array}{l}\text { Uniformemente } \\
\text { distribuída }\end{array}$ & Periódicas & Periódicas \\
\hline Deficiência hídrica & Nula & $\begin{array}{c}\text { De pequena a } \\
\text { moderada (no inverno) }\end{array}$ & Moderada (no inverno) \\
\hline
\end{tabular}

Fonte: Golfari, 1978.

*ombrófila=pluvial

Como a produção de eucalipto, no presente estudo, destina-se à madeira serrada, será adotado o ciclo de 14 anos, pois é o tempo mínimo necessário para que a cultura atinja as características para tal.

Quando se trata de cultivo florestal - seja para a obtenção do produto final para celulose, papel, chapas, carvão vegetal ou madeira serrada - a produtividade, na maioria das vezes, é expressa em metros cúbicos por hectare $\left(\mathrm{m}^{3} / \mathrm{ha}\right)$ e não em toneladas por hectare (ton./ha), como é comum nas demais culturas, como milho, arroz, feijão, soja, entre outras. Como o interesse, no caso particular do 
projeto, é tanto na obtenção de produção de madeira serrada (que é dado em metros cúbicos), como no acúmulo de carbono na biomassa (que é dado emmetros cúbicos e toneladas), será feita a conversão para metros cúbicos ou toneladas sempre que necessário ${ }^{44}$.

\subsection{Custos relacionados à cultura}

Sabido que o foco deste estudo é a discussão da viabilidade na implementação de um projeto florestal para fins de MDL, serão dados os custos de implantação, manutenção e colheita da cultura de eucalipto, sem maiores discussões a respeito das etapas desenvolvidas nestas atividades.

Os dados apresentados a seguir, foram cedidos pela empresa florestal Aracruz Celulose S. A. e são referentes a um ciclo de cultivo de 14 anos:

- Espaçamento - $3 \times 3 \mathrm{~m}$;

- Implantação - R\$ 1903/hectare;

- Manutenção - R\$2431/hectare

- Desbastes - 1;

- Idade -5 anos;

- Volume colhido - $100 \mathrm{~m}^{3} /$ hectare - fins para celulose;

- Custo-R $\$ 13,78 / \mathrm{m}^{3}$;

- Produção final

- $90-120 \mathrm{~m}^{3} /$ hectare - fins para serraria;

- $190-210 \mathrm{~m}^{3} / \mathrm{hectare}$ - fins para celulose;

- Custo da colheita $-\mathrm{R} \$ 13,78 / \mathrm{m}^{3}$.

Outros valores utilizados para a análise econômica são os seguintes:

- Madeira serrada de eucalipto para vigamento* $(6 \mathrm{~cm} \times 12 \mathrm{~cm})$ - $\mathrm{R} \$ 300,00$;

44 Para o eucalipto, os números de conversão são os seguintes: madeira com casca: $1 \mathrm{st}=0,7 \mathrm{~m}^{3}=$ 0,608 ton./madeira sem casca: $1 \mathrm{st}=0,61 \mathrm{~m}^{3}=0,577$ ton. Fonte: IPEF. 
- Madeira para fins de celulose $\left(\mathrm{m}^{3}\right)$ - $\mathrm{R} \$ 28,00$

- Custos de transação para implementação do MDL (auditoria + Linha de Base US\$ - 60.000/projeto;

- Custo de processamento da madeira para serraria ${ }^{45}$ - US\$31/ $\mathrm{m}^{3}$.

- Valor estimado a ser pago pela tonelada de carbono para projetos florestais US\$ $4-7$.

${ }^{*}$ Fonte: CEPEA

O preço de madeira serrada de eucalipto foi obtido no Centro de Estudos Avançados em Economia Aplicada (CEPEA) da ESALQ/USP. Foi calculada a média dos valores médios praticados em fevereiro de 2002, nas regiões de Bauru, Campinas, Marília e Sorocaba, para estes dois produtos.

O valor do preço pago pelo metro cúbico de madeira destinada a celulose foi obtido através de consulta a $\operatorname{AMBROGI}^{46}$ (2002), da empresa florestal Aracruz Celulose S.A.

O valor estimado dos custos de transação necessários para a participação de um projeto no MDL, assim como o preço praticado da tonelada de carbono para projetos florestais, foram obtidos através de consulta a FUJIHARA (2002).

Foram adotados os custos de processamento da madeira para serraria através do levantamento de STONE (2000), onde o valor estimado é calculado em dólares por metro cúbico de madeira processada.

\footnotetext{
${ }^{45} \mathrm{O}$ custo de processamento da madeira serrada foi baseado em STONE (2000). O dado obtido é uma média dos valores de serrarias grandes (caracterizadas por possuírem de 2 a 5 serras-de-fita principais) de três cidades do Pará: Breves, Paragominas e Tailândia. Estes números são dados em dólar e são referentes ao ano de 1995.

${ }^{46}$ AMBROGI, M. S. Gerente de Planejamento Florestal da empresa Aracruz Celulose S.A. Consulta feita por telefone em 11/04/2002.
} 


\subsection{Metodologia da análise econômica}

Para a análise econômica, foram calculados os índices econômicos de taxa interna de retorno (TIR) e do valor presente líquido (VPL), índices indispensáveis para se aferir a viabilidade econômica do projeto. A TIR, expressa em porcentagem, "é a taxa que equaliza o valor presente de um ou mais pagamentos, com o valor presente de um ou mais recebimentos" (SOBRINHO, 2000). Segundo o mesmo autor, o VPL, expresso em valor monetário, "é uma técnica de análise de fluxos de caixa que consiste em calcular o valor presente de uma série de pagamentos (ou recebimentos) iguais ou diferentes a uma taxa conhecida e deduzir deste o valor do fluxo inicial". Significa o mesmo que calcular qual seria o saldo no final do projeto, trazendo-se os valores para o presente.

Os cálculos foram feitos para uma atividade de reflorestamento que envolvesse o MDL e outra que não envolvesse este mecanismo de flexibilização.

Como a área a ser utilizada para o projeto perfaz, dentro da regional agrícola de Botucatu, um total de 9.585,3, foram calculados os índices econômicos para as áreas de 500,1.000, 2.000, 5.000, 7.000 e 9.500 hectares.

O preço praticado pela tonelada de carbono tem uma variação de US $\$ 4,0$ a 7,0 . Foi feita a análise para os valores da tonelada de US\$ 4,0 , US $\$ 5,5$ e US\$ 7,0 .

Adotou-se o valor de $\mathrm{R} \$ 300,00$ para o metro cúbico de madeira serrada e o custo de US\$31,0 para o processamento de um metro cúbico desta madeira. 
A conversão do dólar foi feita com a cotação relativa ao dia 28/02/2002 ${ }^{47}$, quando a relação era de $\mathrm{R} \$ 2,35$ x US $\$ 1$. Todos os valores expressos em dólar foram transformados para o real.

Foi utilizada uma taxa mínima de atratividade de $5,75 \%$ ao ano, do Programa Nacional de Agricultura familiar (PRONAF), do Banco do Brasil. Foi escolhida esta taxa por envolver atividades agrícolas familiares, onde se enquadram os moldes de uma cooperativa florestal.

$\mathrm{Na}$ análise econômica não está sendo incluído o valor da terra e do transporte.

Todos os cálculos de viabilidade econômica foram realizados em planilha eletrônica.

Para os custos, foram contabilizados os seguintes itens:

- Custos de transação (auditoria e linha de base);

- Implantação;

- Manutenção;

- Custo de colheita;

- Custo de desbaste;

- Custo do processamento da madeira.

Para a receita, os seguintes itens foram levados em conta:

- Volume de madeira para celulose;

- Volume de madeira para serraria;

- Créditos de carbono. 


\subsection{Resultados e Discussão}

Para os moldes do MDL, o que interessa neste projeto, é o montante final de carbono retido. Como será visto, o rendimento deste projeto para estes fins é muito baixo, tornando necessária uma discussão a respeito do aproveitamento do restante de biomassa produzida e não contabilizada para os mesmos fins da madeira serrada.

No presente trabalho não recorreu-se à técnica de usos múltiplos da área, também conhecido como sistema agroflorestal. Pode-se definir um sistema agroflorestal como a prática de se cultivar em uma mesma área outras culturas em consorciação ou o emprego da atividade pecuária, visando-se uma otimização da área (LIMA, 1996). Segundo o mesmo autor, tais práticas contribuem para o enfrentamento de problemas crônicos como a baixa produtividade, escassez de alimentos e degradação ambiental generalizada. O emprego do sistema agroflorestal pode auxiliar na receita final da cultura, desde que as atividades lá empregadas não firam os objetivos e conceitos básicos do MDL. Com isso ter-seia um aumento na receita do projeto.

Pode-se recorrer, por exemplo, à pecuária por um período de tempo limitado, dentro da parcela onde o eucalipto encontra-se plantado, até que as copas do eucalipto se fechem. O gado não se alimenta das folhas ou do caule do eucalipto, porém pode haver pisoteamento das plantas, quando estas ainda se encontram pequenas. Deixa-se a cultura em repouso e após três anos, planta-se capim gordura para a alimentação do gado. Este é um dos exemplos de um melhor aproveitamento da área onde está sendo cultivado o eucalipto, assim como o emprego da apicultura, que pode ser uma outra fonte de renda, sem que haja diminuição da produtividade da cultura ou modificação da qualidade de seu produto final.

tp\%3a\%2f\%2fwww\%2eai\%2ecom\%2ebr\%2fpessoal\%2findices> 12/04/2002). 
Através dos dados cedidos pela Aracruz de cultivo de eucalipto para fins de madeira serrada, pode-se calcular para o final do ciclo uma média de produção total da biomassa. Com o objetivo de se facilitar os cálculos, considerar-se-á o volume colhido para serraria de $100 \mathrm{~m}^{3}$ (pois há uma variação na produção de 90 - $120 \mathrm{~m}^{3}$ ) e o volume para celulose de $100 \mathrm{~m}^{3}$ na atividade de desbaste e na colheita, de $200 \mathrm{~m}^{3}$ (quando há uma variação de 190 a $210 \mathrm{~m}^{3}$ ) no final do ciclo de 14 anos e em 1 hectare. Portanto, somando-se o volume de madeira proveniente do desbaste e da colheita, tem-se uma média de $400 \mathrm{~m}^{3} /$ hectare produzidos no final do ciclo. Destes $400 \mathrm{~m}^{3} /$ hectare, somente $1 / 4$ é destinado à serraria, consequentemente, à comercialização de créditos no MDL.

O volume colhido para madeira serrada (100 $\mathrm{m}^{3} /$ hectare), sofre algumas perdas por conta da ineficiência do processo até que sejam transformadas nas serraria. Conforme descrito no item 2.6.2.2., o rendimento adotado no presente trabalho para madeira serrada é de $40 \%$. Significa que dos $100 \mathrm{~m}^{3}$ colhidos para os fins de serraria, serão obtidos somente $40 \mathrm{~m}^{3}$ de produto final. Se este valor for convertido em toneladas de biomassa (considerando-se $1 \mathrm{~m}^{3}$ equivalente a 0,868 toneladas), obtém-se 34,72 toneladas de biomassa por hectare. Como a quantidade de carbono equivale a $50 \%$ da biomassa, tem-se no final do ciclo, em cada hectare, um montante de 17,36 toneladas.

Se toda a área de 9.500 hectares for contabilizada, haverá no final do ciclo de 14 anos um montante de 164.920 toneladas de carbono fixadas para comercialização na forma de créditos de MDL.

Apesar de o volume destinado a celulose ser vendido e gerar receita para o projeto, este pode ser considerado uma perda, sob o ponto de vista do MDL, pois não é contabilizado para comercialização de créditos. Ao todo, são produzidos $300 \mathrm{~m}^{3}$ de madeira para celulose, referentes a $3 / 4$ de toda a produção, sem o menor aproveitamento para os fins de MDL. A quarta parte, relativa à madeira colhida para serraria, sofre uma perda significativa em seu processo. Dos $400 \mathrm{~m}^{3}$ finais por hectares, apenas 1/10, ou $40 \mathrm{~m}^{3}$ têm valor para créditos no MDL. 
Se a produção final total desta área de 9.500 hectares $\left(400 \mathrm{~m}^{3} /\right.$ hectare) fosse considerada para a comercialização de créditos sem que houvesse perdas, poderiam ser contabilizadas 1.649.200 toneladas de carbono. Estes números mostram uma baixa eficiência no processo de conversão, quando há intenção na venda de créditos para MDL.

O volume perdido na serraria $(60 \%$ de toda madeira que ingressa na operação) e o volume relativo à biomassa destinada à celulose, não são contabilizados por não haver segurança na permanência do carbono neste material. Tanto no caso supracitado, como no caso da madeira serrada, é necessário que se prove a permanência do carbono. As certezas envolvidas ditarão o preço da tonelada dentro do projeto.

As tabelas 5.6. e 5.7. demonstram os valores finais das análises econômicas feitas com as variáveis de preço para a madeira serrada, com e sem a participação do projeto no MDL.

Tabela 5.6. - Relação entre a área do projeto e os índices econômicos, considerando o emprego do MDL.

\begin{tabular}{|c|c|c|c|c|c|c|}
\hline & \multicolumn{2}{|c|}{ US\$ 4/ton. de C } & \multicolumn{2}{c|}{ US\$ 5,5/ton. de C } & \multicolumn{2}{c|}{ US\$ 7/ton. de C } \\
\hline Área (há) & $\mathrm{TIR}(\%)$ & $\mathrm{VPL}(\mathrm{R} \$)$ & $\mathrm{TIR}(\%)$ & $\mathrm{VPL}(\mathrm{R} \$)$ & $\mathrm{TIR}(\%)$ & $\mathrm{VPL}(\mathrm{R} \$)$ \\
\hline $\mathbf{5 0 0}$ & 6.22 & 71.528 .57 & 6.30 & 84.755 .93 & 6.39 & 97.983 .29 \\
\hline $\mathbf{1 . 0 0 0}$ & 6.69 & 276.390 .47 & 6.77 & 302.845 .19 & 6.86 & 329.299 .91 \\
\hline $\mathbf{2 . 0 0 0}$ & 6.94 & 686.114 .27 & 7.02 & 739.023 .71 & 7.10 & 791.933 .16 \\
\hline $\mathbf{5 . 0 0 0}$ & 7.09 & 1.915 .285 .67 & 7.17 & 2.047 .559 .28 & 7.26 & 2.179 .832 .89 \\
\hline $\mathbf{7 . 0 0 0}$ & 7.12 & 2.734 .733 .28 & 7.20 & 2.919 .916 .33 & 7.29 & 3.105 .099 .38 \\
\hline $\mathbf{9 . 5 0 0}$ & 7.14 & 3.759 .042 .78 & 7.22 & 4.010 .362 .64 & 7.31 & 4.261 .682 .50 \\
\hline
\end{tabular}

Fonte: Resultados da pesquisa.

A tabela 5.6. expõe os resultados da análise econômica do projeto florestal, com a participação do MDL. Nesta tabela, pode-se observar uma pequena variação na TIR, dentro dos estratos ecolhidos, desde $6,22 \%$ até $7,31 \%$. O projeto mostrou-se viável economicamente para os três valores relacionados da tonelada de carbono e para todas as áreas envolvidas nos cálculos. 
Tabela 5.7. - Relação entre a área do projeto e os índices econômicos, sem a participação dos créditos de MDL.

\begin{tabular}{|c|c|c|}
\hline Área (há) & TIR(\%) & VPL (R\$) \\
\hline $\mathbf{5 0 0}$ & 6.96 & 169.588 .94 \\
\hline $\mathbf{1 . 0 0 0}$ & 6.96 & 339.177 .88 \\
\hline $\mathbf{2 . 0 0 0}$ & 6.96 & 678.355 .75 \\
\hline $\mathbf{5 . 0 0 0}$ & 6.96 & 1.695 .889 .38 \\
\hline $\mathbf{7 . 0 0 0}$ & 6.96 & 2.374 .245 .13 \\
\hline $\mathbf{9 . 5 0 0}$ & 6.96 & 3.222 .189 .82 \\
\hline
\end{tabular}

Fonte: Resultados da pesquisa.

A tabela 5.7. apresenta os índices econômicos sem a participação no MDL. Ou seja, neste caso não são considerados os custos de transação iniciais, referentes à validação do projeto e a baseline, itens necessários para qualquer projeto participar do MDL. Nos valores expressos acima, não é contabilizada a comercialização final dos créditos relativos ao carbono retido na biomassa destinada à madeira serrada. Através desta tabela, pode-se concluir que a atividade é economicamente viável para todos os estratos estudados, apresentando uma TIR de 6,96\%.

Se as tabelas 5.6. e 5.7. forem comparadas, pode-se observar que não há uma diferença considerável quando o MDL faz parte do projeto. Em alguns casos, inclusive, a não participação destes mecanismo é mais vantajosa do que a participação. Para as áreas de 500 e 1.000, não é viável o emprego do MDL, pois na sua ausência, o retorno é maior. A partir do estrato de 2.000 hectares, passa a ser vantajoso o emprego do MDL para o projeto, embora haja uma diferença de ganho pouco expressiva. Isto ocorre devido ao alto valor a ser pago no início do projeto por conta dos custos de transação e da Linha de Base. Com a inclusão do $\mathrm{MDL}$, quanto maior a área, mais pulverizados serão os custos iniciais no final do projeto. Por este motivo, em pequenas áreas a inviabilidade de aplicação do MDL é clara.

O preço baixo da tonelada de carbono pode ditar a viabilidade deste projeto florestal. As incertezas que este projeto apresenta são muitas, desde a produtividade, que é dependente de uma série de fatores naturais, até o baixo 
aproveitamento do total produzido, que também pode sofrer uma variação tanto em sua quantidade como em sua qualidade.

O mais importante para um projeto florestal de MDL é o destino final do produto e a permanência do carbono no mesmo. Os gastos com implantação, manutenção e colheita são contabilizados. No entanto, para o MDL, interessa saber quanto de $\mathrm{CO}_{2}$ será retido com o projeto de reflorestamento.

Através dos cálculos realizados e das tabelas apresentadas, pode-se notar que, em alguns casos, a inclusão do projeto florestal no MDL pode auxiliar economicamente na viabilidade do mesmo. No entanto, o aproveitamento final da biomassa para os fins de serraria são muito baixos. Junta-se a isto o preço pago para os créditos de projetos florestais. São os valores mais baixos da tonelada de carbono, pelos riscos que esta atividade oferece, pela dificuldade de aferição dos números e pelo seu baixo rendimento.

As perdas provenientes da serraria poderiam ser aproveitadas em processos onde a sua durabilidade (portanto, permanência do carbono) fosse assegurada. Desta maneira poder-se-ia tentar o seu emprego no MDL.

É possível aplicar a mesma idéia para a biomassa destinada à celulose. Parte desta produção poderia ser aproveitada para serraria e a parte destinada à celulose, contaria créditos a um valor inferior ao praticado para madeira serrada.

Para provar-se a permanência do carbono nos dois casos citados acima, é necessário que a Linha de Base do projeto apresente metodologia convincente. Mesmo assim, o valor da tonelada seria inferior por conta das incertezas que estes produtos finais apresentam.

O projeto da Plantar, citado no item 1.9.1., é considerado de substituição energética, embora se utilize da produção florestal como etapa intermediária do 
processo. Esta empresa usa a madeira de eucalipto como processo intermediário para produção de ferro-gusa. O projeto foi aceito por se comprovar a redução de emissão do carbono por conta da substituição do carvão mineral pelo carvão vegetal. Os custos de transação deste projeto, por sua complexidade, foram de US\$ 400.000 .

Os custos de transação e da Linha de Base estimados para o presente projeto são teoricamente mais baixos pela simplicidade da metodologia apresentada. Por este mesmo motivo, os valores dos créditos tendem a ser inferiores. O sucesso do projeto florestal, portanto, como uma atividade de MDL, está diretamente ligado às certezas que o mesmo traz quanto à permanência do carbono; e também aos preços pagos pela tonelada de carbono, que estão inversamente relacionados aos riscos que este projeto oferece. 


\section{Capítulo VI}

Através das discussões desenvolvidas neste trabalho e com o exercício teórico acerca de uma área para implementação de um projeto florestal para os fins de MDL, pode-se tecer as seguintes conclusões:

- O Brasil tem plenas condições de desenvolvimento de projetos florestais com espécies do gênero Eucalyptus para fins de MDL, por suas características de clima, solo e extensão territorial. Há também estudos de melhoramento genético e produtividade desenvolvidos para tal gênero, conforme descrito no capítulo II;

- As cooperativas podem ser uma opção para a implementação de projetos florestais, devido ao ganho de escala, disposição de mão-deobra e a oferta de trabalho e receita a agricultores proprietários de pequenas áreas de uma mesma região. Torna-se difícil, no entanto, a execução de um projeto deste porte sem o auxílio do governo ou ajuda financeira externa, devido ao giro de capital necessário no início do projeto, por parte dos custos de transação (conforme visto no capítulo V);

- A atividade de reflorestamento sugerida no presente trabalho pode reter, no final do ciclo de 14 anos, 17,36 toneladas de carbono/hectare, de acordo com os dados sugeridos. Se toda a área de 9.500 hectares for contabilizada (relativa à maior parcela de área calculada no exercício, no capítulo V), haverá no final do ciclo de 14 anos, um montante máximo de 
164.920 toneladas de carbono fixadas para comercialização na forma de CRE's no MDL;

- Somente um décimo da produção total do projeto destina-se à comercialização dos créditos de carbono, o que demosntra um rendimento final baixo, se comparado ao volume de biomassa total produzido no final do ciclo. O restante caracteriza-se por perda no processamento da madeira para fins de serraria e no destino da madeira para celulose;

- O volume destinado à celulose representa $75 \%$ de toda a produção final. Se houvesse contabilização do carbono neste caso, a receita gerada poderia trazer ganhos consideráveis ao projeto;

- O projeto é considerado economicamente viável nos dois casos, com e sem o emprego do MDL. Com o emprego do MDL, a TIR sofreu uma variação de $6,22 \%$ até $7,31 \%$. Quando o MDL não é considerado no projeto, este apresenta uma TIR de 6,96\%. Para as parcelas de 500 e 1.000 hectares, o projeto que recebe o MDL tem uma receita menor daquele que não considera este mecanismo em seus cálculos. Portanto, há casos em que há viabilidade econômica do projeto, mas este não é atrativo economicamente;

- As atividades florestais para MDL lidam com dois pontos que ditam o preço da tonelada de carbono e, muitas vezes, a viabilidade do projeto: permanência do carbono e riscos do projeto. Quanto maior a certeza da permanência do carbono no material ou no processo, maiores serão os preços pagos pelos créditos. Quanto menores os riscos atrelados ao projeto, menor será a oscilação de preço da tonelada de carbono. 
Através das discussões travadas e das conclusões apresentadas, sugere-se para futuros trabalhos e pesquisas dentro do seguinte foco:

- Potencial de cooperativas como candidatas a projetos de MDL em setores que possibilitem um ganho de escala de produção;

- Celulose proveniente do processo de reflorestamento para fins de MDL, suas implicações e possibilidades;

- Melhoria no rendimento e na obtenção da madeira serrada como produto final;

- Aproveitamento das perdas de serraria para inclusão no MDL e contagem de créditos;

- Estudo do processo florestal como um todo, buscando aproveitar toda e qualquer etapa que envolva redução de emissões de carbono, com o objetivo de agregar um maior valor ao projeto, tornando-o mais atraente economicamente. 


\section{L - Glossário}

Alburno - É a porção do tronco mais próxima da casca da madeira e de menor durabilidade, devido à grande quantidade de substâncias nutritivas nela encontrada e que são atacadas por organismos xilófagos.

Alelopatia - Interferência de uma planta sobre outra através de substâncias produzidas pela planta e liberadas ao meio.

Angiospermas - Plantas que possuem sementes protegidas pelo fruto.

Antrópico - Ação causada pelo homem.

Apicultura - Atividade que consiste na criação de colméias de abelhas melíferas para extração de mel e própolis.

Área complementar - É a área ocupada com benfeitorias (casa, curral, represas e estradas).

Área de Proteção Ambiental - Extensas áreas que posuem ecossistemas de importância, englobando um ou mais atributos ambientais.

Área inaproveitada - Conjunto das áreas que não estão sendo aproveitadas, mas que apresentam potencial para isso. Inclui áreas ocupadas por várzeas, brejos e similares, localizadas às margens de córregos, rios e lagoas.

Área inaproveitável - são consideradas nesta categoria as áreas do grupo C, classe VIII, da capacidade do uso de terras impróprias para cultura, pastagem ou reflorestamento, podendo servir como abrigo e proteção da fauna e flora silvestres, ambiente de recreação, etc. Ou, simplesmente, podem ser consideradas áreas que não constam em nenhuma das outras categorias, incluindo mangues e pântanos.

Biomassa - Denominação dada à massa vegetal de uma área específica.

Biosfera - É o conjunto de regiões da Terra onde existe vida.

Capoeira - Refere-se ao tipo de vegetação que representa a fase inicial de regeneração de uma mata natural. 
Caule - O mesmo que tronco ou fuste, o caule é a parte aérea da planta compreendida entre o nível do solo e as ramificações da copa.

Celulose - Celulose é um polissacarídeo formado por unidades de monossacarídeo $\beta$-D-glicose que se ligam entre si através dos carbonos 1 e 4 , dando origem a um polímero linear, capaz de formar um arranjo fibroso (fibra celulósica). A celulose constitui cerca de $50 \%$ da madeira.

Cerne - Porção do tronco mais interna, sendo mais resistente que o alburno. Considera-se o cerne, o alburno envelhecido.

Cerrado/Cerradão - Formação característica de vegetação, que apresenta árvores baixas, retorcidas, com casca grossa e um tapete de gramíneas por baixo.

Ciclo - Período que se estabelece em uma cultura silvícola, em anos, com a variação dependente da finalidade pretendida com o produto final.

Ciclo curto - Ciclo de produção curto, no qual a colheita se dá de 7 a 10 anos após o plantio ou após a rebrota.

Ciclo longo - Ciclo com maior duração de tempo, sendo geralmente de 20 a 25 anos para a cultura do eucalipto.

Cultura anual - Também conhecidas como temporárias, as culturas anuais são aquelas que completam o seu ciclo de vida dentro de uma estação, perecendo após a colheita. São exemplos de culturas anuais as olerícolas (verduras e legumes) e as flores.

Cultura perene - Conhecidas também como permanentes, as culturas perenes são aquelas que crescem de ano para ano, sendo muitas vezes necessário um período de vários anos para que se tornem produtivas. Elas não perecem necessariamente após a colheita. Exemplos: café, laranja, coco, abacate.

Cultura semi-perene - Também chamadas de bienais, as culturas semi-perenes são aquelas que normalmente completam seu ciclo num período de duas ou mais estações de crescimento. São exemplos de cultura semi-perene, o abacaxi, banana, cana-de-açúcar e mamão.

Desbaste - Trato cultural que consiste na retirada de árvores menores ou mal formadas dentro de um talhão, para que as árvores remanescentes possam se desenvolver melhor. 
Desdobro - Corte das toras feito pelas serrarias para a formação de pranchões, tábuas e vigas.

Dicotiledôneas - Grupo de plantas caracterizado por possuírem raízes ramificadas, dentre as quais se destaca uma principal; as folhas têm uma inervação reticulada e as pétalas das flores são organizadas à base dos números 2 e 5 ou seus múltiplos. $O$ frutos com número de lojas à base de 2 e 5 ; possuem 2 cotilédones que podem funcionar como órgão de reserva.

Dossel - Extrato superior de uma floresta, composto pelo conjunto das copas das árvores.

Ecossistema - Sistema complexo de organismos que compõem uma comunidade, formando um ambiente.

Edafoclimático - Termo técnico usado onde a cultura em questão é relacionada aos fatores de solo e clima do local.

Endemismo - Ocorrência natural de uma espécie naquele local.

Espécie exótica - Consiste naquela espécie que foi estabelecida pela primeira vez em um local situado a distâncias significativas de sua região de ocorrência natural.

Espécie nativa - Consiste nas espécies de ocorrência natural na região, sem que tenham sido introduzidas pelo homem.

Estere - Unidade de volume de madeira, representando o volume de uma pilha de madeira (altura $X$ largura $X$ comprimento).

Estípula - Apêndice de tamanho quase sempre reduzido e em número de dois e que se encontra na base da folha.

Exudação - Transpiração.

Feromônio - Substâncias liberadas pelos animais e que têm influência sobre o comportamento dos indivíduos da mesma espécie.

Floresta - Estrutura complexa de vegetação, dominada por árvores de poucas a várias espécies, onde as copas das árvores se tocam, resultando em um ambiente fechado. A estrutura dessas florestas é variavél de acordo com as condições do meio ambiente.

Florestas Naturais - Como já diz o nome, essas florestas são as de ocorrência natural, sem que tenha havido intervenção do homem na sua formação. 
Florestas Plantadas - São assim conhecidas as florestas que receberam intervenção do homem no seu plantio e que geralmente têm finalidade de aproveitamento posterior na forma de lenha, madeira serrada, celulose, papel, carvão vegetal, etc.

Folhosas - Grupo de espécies de árvores que se caracterizam de uma forma geral por apresentarem folhas largas e planas e flor. O eucalipto é exemplo de uma espécie folhosa.

Fuste - Vide caule.

Gimnosperma - Planta que não possui suas sementes protegidas por um fruto.

Habitat - Local onde cresce e se desenvolve um determinado ser vivo.

Hectare - Medida de área geralmente usada para demarcação de terras agrícolas. Um hectare equivale a $10.000 \mathrm{~m}^{2}$.

Hemicelulose - É um termo utilizado para designar uma mistura de polímeros polissacarídeos de baixa massa molecular, intimamente associados com a celulose nos tecidos das plantas. Diferentemente da celulose, que contém apenas o monossacarídeo glicose, cada polímero que compõe a celulose apresenta mais de um tipo de monossacarídeo, cadeia ramificada e não é capaz de formar arranjo fibroso. Nas folhosas, como o eucalipto, os polissacarídeos que compõem a hemicelulose são: arabinogalactana, galactoglucamanana, glucomanana, arabinoglucouranoxilana e glucouranoxilana, sendo este último o principal.

Incremento médio anual - Taxa de crescimento de uma cultura, relacionada à área ou à produtividade.

Latifoliada - Característica de formação ou espécies florestais que contenham folhas largas.

Lignina - É um produto polimérico natural, cuja estrutura provém da polimerização dos seguintes precursores primários: álcool trans-coniferílico (grupo guaiacil), ácool trans-sinpílico (grupo siringil) e álcool trans-para-cumárico (grupo para hidroxifenil). Nas folhosas, como o eucalipto, prevalece o grupo siringil.

Lixiviação - Carregamento dos nutrientes através da lavagem do solo com o excesso de água.

Monocotiledôneas - Grupo de plantas caracterizado por apresentar as raízes fasciculadas (ou em cabeleira), folhas com nervuras dispostas paralelamente. As 
pétalas de suas flores são organizadas à base do número 3 ou o seu múltiplo. As sementes possuem um só cotilédone, este reduzido e que não funciona como órgão de reserva.

Monocultura - Cultura de uma única espécie em uma área em questão.

Organela - Designação dada a órgãos de tamanho microscópico que se encontram dentro de outros órgãos e desempenham uma função.

Partes - Países constituíntes da Convenção-Quadro sobre Mudanças Climáticas.

Pastagem cultivada - Também conhecida como formada ou artificial, é aquela área onde se plantou capim (braquiária, capim-gordura, capim-colonião, capimjaraguá) e é destinada à exploração animal.

Pastagem natural - Área de pastagem extendida, não cultivada e que é efetivamente utilizada em exploração animal.

Pecuária - Atividade que consiste na criação de rebanho bovino, ovino ou caprino, para extração de leite, aproveitamento da carne e do couro.

Permeabilidade - Que permite a penetrabilidade de uma substância em um material.

Polissacarídeos - São polímeros constituídos por muitas unidades - centenas, ou mesmo milhares - de monossacarídeos. Os polissacarídeos mais importantes são a celulose e o amido.

Quebra-vento - Barreira física formada por plantas, geralmente de porte médio ou alto, com a função de proteger culturas dos ventos fortes.

Rebrota - Brotação do eucalipto após o corte das árvores.

Reflorestamento - Recomposição de uma área já degradada com espécies florestais. O reflorestamento pode ser misto ou homogêneo, com espécies exóticas ou nativas.

Reflorestamento homogêneo - Reflorestamento feito em uma área com apenas uma espécie.

Reflorestamento misto - Reflorestamento feito em uma área com duas ou mais espécies diferentes.

Reforma - Preparo da área após a colheita para um novo plantio do eucalipto. Geralmente na reforma, são retiradas as raízes e a terra recebe uma adubação de pré-plantio para o preparo do solo. 
Serrapilheira - Camada superficial do solo, constituída por restos vegetais (folhas, galhos) e animais (carcaças).

Simbiose - Associação entre indivíduos de espécies diferentes, não importando o tipo de relação entre eles, na qual ambos se beneficiam.

Talhão - Área de terra delimitada na qual se encontra uma parcela da cultura cultivada.

Taxa interna de retorno - É a taxa que equaliza o valor presente de um ou mais pagamentos com o valor presente de um ou mais recebimentos.

Tronco - Vide caule.

Valor presente líquido - Técnica de análise de fluxo de caixa que consiste em calcular o valor presente de uma série de pagamentos iguais ou diferentes com uma taxa conhecida.

Vegetação natural - Inclui mata natural, capoeira, cerrado, cerradão, campos. Refere-se a florestas ainda intocadas pelo homem, bem como aquelas em adiantado grau de regeneração.

Volatilização - Transformação do estado líquido para o gasoso.

Xilófagos - Organismos (insetos e fungos) que atacam a madeira para se alimentar, baixando a qualidade deste produto e, consequentemente, seu preço no mercado. 
M - Bibliografia

AGÊNCIA BRASIL FHC comemora sucesso das negociações sobre 0 Protocolo de Quioto. (disponível na internet <www.forumclima.org.br> 10/11/2001).

ANDRADE, E.N. O Eucalipto. $2^{a}$ edição Impresso nas Oficinas tipográficas da Companhia Paulista de Estradas de Ferro, 667 p. São Paulo, 1961.

ANGELO, C. Aquecimento global já afeta ecossistemas. Folha de São Paulo, Caderno Ciência p.16, 28/03/2002b.

ANGELO, C. Bush lança alternativa a acordo de Kyoto. Folha de São Paulo, Caderno Ciência p.10, 15/02/2002a..

BANCO NACIONAL DE DESENVOLVIMENTO ECONÔMICO E SOCIAL Efeito Estufa e a Convenção sobre Mudança do Clima. 25p. set. 1999.

BARRICHELO, L.E.G. Apontamentos de química da madeira. ESALQ/DS, Piracicaba 6p. 1973.

BLAND, D.E. The composition and analysis of eucalypt wood. Appita v.38 n.4 p.291-4 jul, 1985.

CAMPANILI, M. Inventário do IBGE é condição para o Brasil ratificar o Protocolo de Kyoto. (disponível na internet <www.forumclima.org.br> 28/02/2002).

CANÇADO, P. Em defesa do verde e das verdinhas. Forbes-Brasil ed. Camelot. ano 2, n.23 p.32-37. São Paulo, ago. 2001. 
CARDOSO, M. Brasil está concluindo inventário sobre emissões de gases de efeito estufa. (disponível na internet <www.forumclima.org.br> 13/03/2002).

CAVALCANTE, M.S. Dados sobre a durabilidade de 182 madeiras. Boletim ABPM n²35, São Paulo, 1983.

CENTRO DE ESTUDOS INTEGRADOS SOBRE O MEIO AMBIENTE E MUDANÇAS CLIMÁTICAS Edital 09/2001- Mudanças climáticas. (disponível na internet <www.centroclima.org.br> 2001).

CHICAGO ClimATE EXCHANGE (disponível na internet $<$ www.chicagoclimatex.com>s.d.).

CÓDIGO FLORESTAL BRASILEIRO. Lei $\mathrm{n}^{\circ} 4.771$ (disponível na internet $<$ www.ipef.br/legislacao/codigo.html> ago. 1997).

CONFERENCE OF THE PARTIES The Marrakesh accords \& the Marrakesh declaration. 245p. (Disponível na internet <www.unfccc.int> 2001).

CONVENÇÃO-QUADRO DAS NAÇÕES UNIDAS SOBRE A MUDANÇA DO CLIMA O Protocolo de Quioto. (disponível na internet <www.mct.gov.br> dez. 1997).

ENVIRONMENT PROTECTION AGENCY Global Warming and our Changing Climate - Answers to Frequently Asked Questions. (disponível na internet $<w w w . e p a . g o v>$ s.d.).

FBDS O sequestro de $\mathrm{CO}_{2}$ e o custo de reflorestamento com Eucalyptus spp e Pinus spp no Brasil. 16p. nov. 1994.

FERREIRA, F.A. Enfermidades do eucalipto. Separata de informe agropecuário v.12 n.141 p.59-70 1986. 
FILHO, E.B \& KRUGNER, T.L. Manejo integrado de pragas e doenças em povoamentos de Eucalyptus no Brasil. Silvicultura. v.11 n.41 p.41-3 1986.

FOELKEL, C.E.B. Constituição Química da madeira. CENIBRA/UFV Viçosa 5p. 1977.

FÓRUM BRASILEIRO DE MUDANÇAS CLIMÁTICAS I Seminário do Fórum Brasileiro de Mudanças Climáticas - Protocolo de Quioto: O Brasil em apoio ao Planeta. ed. Imprensa Oficial, 32p. jun. 2001.

FREITAS, I. FHC assina mensagem que encaminha o Protocolo de Quioto ao Congresso. Agência Brasil (disponível na internet <www.forumclima.org.br> 13/03/2002).

GARCIA, R. Poço de carbono: Peugeot afasta práticas agressivas ao meio ambiente. Brasília, (disponível na internet <www.folhadomeioambiente.com.br> 2001).

GARLIPP, R. Conclusões de Marrakesh. (disponível na internet $<w w w . s b s . o r g . b r>$ nov. 2001).

GAZETA MERCANTIL Brasil terá vantagens no mercado de carbono. (disponível na internet <www.forumclima.org.br> 13/11/2001b.).

GAZETA MERCANTIL Petrobrás e Vale têm projetos ambientais. (disponível na internet <www.forumclima.org.br> 12/11/2001a.).

GAZETA MERCANTIL Retirada de carbono em áreas florestais. 15/08/1999.

GAZETA MERCANTIL Um mecanismo de Desenvolvimento Limpo. (disponível na internet <www.forumclima.org.br> 25/03/2002). 
GOLDEMBERG, J. \& MIGUEZ, J.D.G. O CDM e o Mecanismo de Flexibilidade Implementação Conjunta (JI)/Atividades Implementadas Conjuntamente. (disponível na internet <www.mct.gov.br> jan. 2000).

GOLDEMBERG, J. Energia, Meio Ambiente e Desenvolvimento. Trad. André Koch, Ed. Edusp, 233p. São Paulo, 1998.

GOLDEMBERG, J. S.O.S. Planeta Terra - O Efeito Estufa. Ed. Brasiliense, 72p. São Paulo, 1989.

GOLDERBERG, J. Amazônia e o Protocolo de Kyoto. Jornal O Estado de São Paulo 4 set. 2001a.

GOLFARI, L. CASER, R. \& MOURA, V.P.G. Zoneamento Ecológico Esquemático para Reflorestamento no Brasil. - Série Técnica Prodepef v.11 p.1-66, $1978 \mathrm{~V}$.

HALL, D.O., RAO, K.K. Fotossíntese. Ed. Pedagógica e Universitária 89p. São Paulo, 1980.

HOFFMANN, R., ENGLER,J.J.C., SERRANO, O., THAME, A.C.M., NEVES, E.M. Administração da empresa agrícola. Ed. Livraria Pioneira. 323p. São Paulo, 1976.

INSTITUTO DE ESTUDOS AVANÇADOS Projeto Floram - Uma Plataforma. São Paulo: 301p. IEA. V.4 n.9 maio/ago. 1990.

INTERGOVERNMENTAL PANNEL IN CLIMATE CHANGE sumary for Policymakers - Land Use, Land-Use Change and Forestry. Canadá 1 - 8 maio 2000. 
IPEF Projeto Chave de Identificação de Espécies Florestais (CIEF). (disponível na internet $<w w w$.ipef.br $>$ s.d.).

JOCKYMAN, A. Politicamente correto e rentável. Brasil Energia. n.254 p.40-56 jan. 2002.

JOHN, L. Aquecimento global já tem efeito sobre espécies. (disponível na internet <www.estadao.com.br> 05/08/2001).

JOHN, L. Texaco terá projeto de sequestro de carbono no Brasil. (disponível na internet <www.estadao.com.br> 03/09/2001).

JOLY, A.B. Botânica - Introdução à Taxonomia Vegetal. Companhia Ed. Nacional Edusp 634p. São Paulo, 1966.

JORNAL DO BRASIL Marrakesh dá sinal verde para Quioto. (disponível na internet <www.forumclima.org.br> 12/11/2001).

LEÃO, R.M. A floresta e o homem. IPEF. 434p. Ed. Edusp, Piracicaba, 2000.

LIMA, W.P. Impacto ambiental do eucalipto. Edusp 301p. São Paulo,1996.

LIMA, W.P. O reflorestamento com eucalipto e seus impactos ambientais. Art Press 114p. São Paulo, 1987.

LORENZI, H. Árvores Brasileiras - Manual de Identificação e cultivo de Plantas arbóreas do Brasil. Instituto Plantarum, vol. I, 352 p. São Paulo, 2000a.

LORENZI, H. Árvores Brasileiras - Manual de Identificação e cultivo de Plantas arbóreas do Brasil. Instituto Plantarum, vol. II, 352 p. São Paulo, 2000b. 
MATEOS, S.B. Brasil sequenciará genes do eucalipto. (disponível na internet $<w w w . e s t a d o . e s t a d a o . c o m . b r>23 / 03 / 2001)$.

MINISTÉRIO DA AGRICULTURA E DO ABASTECIMENTO Relação de nomes científicos e designação comum de espécies vegetais. Divisão de Defesa Agropecuária (DDA/RS), Serviço de Sanidade Vegetal (SSV/RS) Documento de divulgação interna 16p. jan. 1998.

MINISTÉRIO DA CIÊNCIA E TECNOLOGIA Estimativa da quantidade de carbono fixados pelas florestas plantadas. (disponível na internet $<$ www.mct.gov.br/clima> 09/04/2001).

MINISTÉRIO DA CIÊNCIA E TECNOLOGIA Protocolo de Quioto à Convenção sobre Mudança do Clima. versão do original publicado pelo Secretariado da Convenção sobre Mudança do Clima. Editado e traduzido pelo Ministério da Ciência e Tecnologia com o apoio do Ministério das Relações Exteriores. 34p. Brasília, maio. 2001.

MINISTÉRIO DE CIÊNCIAS E TECNOLOGIA Brasil inicia o maior experimento florestal do mundo. (disponível na internet <www.mct.gov.br> s.d.).

MINISTÉRIO DO MEIO AMBIENTE Riqueza de espécies. (disponível na internet $<w w w . m m a . g o v . b r>$ s.d.).

MONZONI, M. Mudança Climática - Tomando Posições. - Amigos da TerraAmazônia Brasileira 41 p. São Paulo, set. 2000.

MORA, A.L. \& GARCIA, C.H. A cultura do eucalipto no Brasil. Sociedade Brasileira de Silvicultura 112p. São Paulo, 2000.

NAHUZ, M.A.R. et al. Uso estrutural da madeira de eucalipto: A experiência do IPT. Divisão de Produtos florestais, publicação IPT 2603 9p. São Paulo, 2000. 
NOVAES, W. Novos impasses no clima. (disponível na internet $<$ www.estadao.com.br> 1/03/2002).

O'NEILL, P. Environmental Chemistry. Ed Chapman \& Hall, $2^{\circ}$ edição. Plymouth, UK, 268p. 1994.

PIVETTA, M. Pouco gás na Floresta Amazônica. Pesquisa Fapesp n.72 p.36-43, fev, 2002.

POGGIANI, F. Estrutura, Funcionamento e Classificação das Florestas Plantadas. - Documentos Florestais - Piracicaba (3):1-14 set. 1989.

PROGRAMA NACIONAL DE FLORESTAS Decreto $n^{\circ} 3.420$ de 20 de abril de 2000. (disponível na internet <www.mma.gov.br>s.d.).

RABELLO, T. Estudo aponta falta de madeira em SP. (Disponível na internet $<$ www.estado.estadao.com.br>13/03/2002).

RAMADE, F. Elementos de Ecologia Aplicada. Versão espanhola de HERNANDEZ, J. E. Ed. Ediscience Mc Graw-Hill 581p. 1977.

RAVEN, P.H., EVERT, R.F. \& EICHHORN, S.E. Biologia Vegetal. $5^{\text {a }}$ edição Guanabara Koogan 728p. 1996.

REUTERS Aquecimento global quebra geleira gigante. Folha de São Paulo, Caderno Ciência p.15, 20/03/2002.

REZENDE, D., MERLIN, S. \& SANTOS, M. Sequestro de Carbono - Uma experiência concreta. Segunda edição revisada e ampliada 178p. Palmas: Instituto Ecológica, 2001. 
RODÉS, L. Setor Florestal no Brasil. Klabin Papel e Celulose S.A. (disponível na internet $<>$ s.d.).

RODRIGUES, R. Bela idéia. Artigos Florestais IPEF. Artigo publicado na Revista Agroanalysis; vol.19 n¹2 dez. 1999.

SAGAN, Carl. Cosmos. ed. Francisco Alves; trad. Angela do Nascimento Machado. Revisão técnica: Airton Lugarinho de Lima Câmara. 364p. Rio de Janeiro, 1982.

SECRETARIA DA AGRICULTURA E DO ABASTECIMENTO Projeto LUPA manual de instruções de campo. Secretaria da Agricultura e do Abastecimento Levantamento Censitário de Unidades de Produção Agropecuária 58p. São Paulo, 1995.

SILVA, J.C. Eucalipto - A Madeira do Futuro. Curitiba: Revista da Madeira 114p.il. set. 2001.

SINGER, P. Alternativas para enfrentar a crise. Debates \& Reflexões $n^{\circ} 6$ p.6271 São Paulo, Ago. 1999.

SINGER, P. Economia pode rimar com solidariedade. Sem Fronteiras, $n^{\circ} 287$ p.5-7, São Paulo, mar. 2001.

SINGER, P. \& SOUZA, A. R. A economia solidária no Brasil - A autogestão como resposta ao desemprego. (vários autores) Ed. Contexto Coleção economia 360 p. São Paulo, 2000.

SINGER, P. Economia solídária - Histórico. Caderno da Oficina Social, n5 p.58 Rio de Janeiro, 2000b. 
SMERALDI, R. \& VERÍSSIMO, A. (Direção e redação) Vários autores Acertando o alvo - Consumo de madeira no mercado interno brasileiro e promoção da certificação florestal. Friends of the Earth/ Amigos da Terra/ Programa Amazônia 41p. São Paulo, 1999.

SOBRINHO, J.D.V. Matemática financeira. Ed. Atlas; 409p. São Paulo, 2000.

STONE, S.W. Tendências econômicas da indústria madeireira no estado do Pará. Trad. Glaucia Barreto. Série Amazônia, n.17. 38p. (disponível na internet $<w w w$.imazon.org.br> 29/04/2002) Belém, 2000.

TEIXEIRA, M. Brasil vai Integrar Comitê de Clima em Marrakech. Folha de São Paulo (disponível na internet <www.uol.com.br/folha/ciencia> 6/11/2001).

TETTI, L. Mecanismo de Desenvolvimento Limpo. Conselho Empresarial Brasileiro para o Desenvolvimento Sustentável 35p. Rio de Janeiro, 2001a.

TETTI, L. Mercado de carbono. Conselho Empresarial Brasileiro para o Desenvolvimento Sustentável 19p. Rio de Janeiro, 2001b.

THEODORE, D., HELMS, J.A. \& BAKER, F.S. Princípios de Silvicultura. Trad. MATA, R.E. Ed. Mc Graw-Hill 490p. México,1979.

VITAL, B.R. \& DELLA LUCIA, R.M. Propriedades físicas e mecânicas da madeira de eucalipto. Informe agropecuário v.12 n.141 p.71-3 Belo Horizonte. set. 1986.

WATAI, L. T. Substituição de espécies de madeiras nativas por madeiras de reflorestamento. Boletim ABPM n7 16p. São Paulo, abr. 1991.

WILSON, E.O. (editor) Biodiversidade. Trad. Marcos Santos/Ricardo Silveira Ed. Nova Fronteira 657p. 1988. 
WORLD RESOUCERS INSTITUTE World Resources 2000-2001 People and Ecosystems- The Fraying Web of Life. 387p. Washington D.C, 2001.

WORLD RESOURCES INSTITUTE Factores del Deterioro de la Biodiversidad. (disponível na internet <www.wri.org> s.d.). 
N - Sites consultados

ACI - Aliança Cooperativa Internacional - www.coop.org/ica/pt

ARACRUZ - www.aracruz.com.br

Banco do Brasil - www.bancodobrasil.com.br

CATI -Coordenadoria de Assistência Técnica Integral - www.cati.sp.gov.br

CEBDS - Conselho Empresarial Brasileiro de Desenvolvimento Sustentável www.cebds.com

Centro Clima - Centro de Estudos Integrados sobre Meio Ambiente e Mudanças

Climáticas - www.centroclima.org.br

EPA - Environmental Protection Agency - www.epa.gov

FAO - Organização das Nações Unidas para Agricultura e Alimentação www.fao.org

Folha do Meio Ambiente - www.folhadomeioambiente.com.br

Fórum Brasileiro de Mudanças Climáticas - www.forumclima.org.br

FUNDO FLORESTAR - www.floresta.org.br

IBAMA - Instituto Brasileiro do Meio Ambiente e dos Recursos Naturais

Renováveis - www.ibama.gov.br

IBGE - Instituto Brasileiro de Geografia e Estatística - www.ibge.gov.br

IEA - Instituto de Economia Agrícola - www.iea.sp.gov.br

INPE - Instituto Nacional de Pesquisas Espaciais - www.inpe.br

IPCC - Intergovernmental Pannel on Climate Change - www.ipcc.ch

IPEF - Instituto de Pesquisas Florestais - www.ipef.br

Madeira total - www.madeiratotal.com.br

Madeiras do Brasil - www.madeirasdobrasil.eng.br

MCT - Ministério de Ciência e Tecnologia - www.mct.gov.br

MMA - Ministério do Meio Ambiente - www.mma.gov.br

O Estado de São Paulo - www.estadao.com.br

Plantar - www.plantar.com.br

SBS - Sociedade Brasileira de Silvicultura - www.sbs.org.br

Secretaria de Estado do Meio Ambiente - www.ambiente.sp.gov.br 
Site dos índices - http://64.4.22.250/cgi-

bin/linkrd?_lang=EN\&lah=8f1b1b26c6529cb4f029d749d2e9c2ef\&lat=1020198296 \&hm__action=http\%3a\%2f\%2fwww\%2eai\%2ecom\%2ebr\%2fpessoal\%2findices SPVS - Sociedade de Pesquisa em vida silvestre e educação ambiental www.spvs.org.br

UNFCCC - United Nations Framework Convention on Climate Change www.unfccc.int

WRI - World Resources Institute - www.wri.org 


\section{O - Relação de consultas e entrevistas realizadas}

AMBROGI, M. S. Gerente de Planejamento Florestal da Empresa Aracruz

Celulose S.A. Consultas feitas por telefone, em São Paulo, em 11/04/2002 e 03/05/2002.

FREITAS, A.R. Consultor em Silvicultura. Consulta feita por telefone, em São Paulo, em 12/03/2002.

FUJIHARA, M. A. Consultor em MDL. Entrevista concedida em São Paulo, em 24/02/2002.

GARLIPP, R. Superintendente da Sociedade Brasileira de Silvicultura; Entrevista concedida em São Paulo em 13/03/2002.

GOLDEMBERG, J. Prof. Titular do PIPGE-USP- Entrevista concedida em São Paulo, em 21/10/2001.

GONÇALVES, J.L.M. Prof. Titular do Departamento de Ciências FlorestaisESALQ-USP - Entrevista concedida em Piracicaba, 04/10/2001.

LAMARDO, M.L.O.A. Especialista na área de celulose e papel - IPT - USP Consulta em São Paulo, em 26/03/2002.

LIMA, W.P. Prof. Titular do Departamento de Ciências Florestais- ESALQ-USP Entrevista concedida em Piracicaba, 15/08/2001.

MIGUEZ, J.D.G. Secretário Executivo da Comissão Interministerial de Mudança Global do Clima - Consulta via internet, em 27/02/2002.

NAHUZ, M.A.R. Pesquisador da Divisão de Produtos Florestais - IPT/USP Entrevistas concedidas em São Paulo, 08/10/2001, 26/02/2002 e 02/05/2002. 
SIMÕES, J.C. - Consultor em madeira e seus produtos - IEE - USP - Entrevistas concedidas em São Paulo, em 5/12/2001, 26/12/2001 e 15/02/2002.

SINGER, P. Prof. Titular da Faculdade de Economia e Administração. Entrevista concedida em São Paulo, em 14/03/2002. 
P - Anexos

A 1 - Entidades participantes do projeto Chicago Climate Exchange:

Energy - Alliant Energy, BP, Calpine, Cinergy, DTE, Exelon, Midwest Generation, Ni Source, PG\&E National Energy Group, Pinnacle West Corporation (APS), Suncor Energy, Wisconsin Electric Power.

Industry - Ford Motor Company, Du Pont, ST Microelectronics, Inteface, Waste Management Inc.

Offset providers - griliance, Growmark, lowa Farm Bureau Federation, National Council of Farmer Cooperatives, Ormat, Nuon, The Nature Conservancy, Zahren Alternaative Power Corporation.

Forest Products Companies - International Paper, Temple-Inland, Mead Corp., Klabin S.A.

\section{A 2 - Preços de madeira praticados no mercado}

- Madeira serrada de eucalipto para vigamento* $(6 \mathrm{~cm} \times 12 \mathrm{~cm})$ - $\mathrm{R} \$$ 300,00 ;

- Madeira para fins de celulose $\left(\mathrm{m}^{3}\right)$ - $\mathrm{R} \$ 35,00$ (fonte: ABRACAVE)

${ }^{*}$ Fonte: CEPEA. 